九州大学学術情報リポジトリ

Kyushu University Institutional Repository

\title{
Fusulines of the Middle Permian Kozaki Formation of Southern Kyushu
}

Kanmera, Kametoshi

Faculty of Science, Kyushu University

https://doi.org/10.5109/1543606

出版情報：九州大學理學部紀要：Series D, Geology. 14 (2)，pp.79-141，1963-03-01. Faculty of Science, Kyushu University バージョン：

権利関係 : 
Mem. Fac. Sci., Kyushu Univ., Ser. D, Geology, Vol. XIV, No. 2, pp. 79-141, test-figs. 1-3, tables 1-9, pls. 11-19, March 1963.

\title{
Fusulines of the Middle Permian Kozaki Formation
}

\author{
of Southern Kysuhu*
}

By

\section{Kametoshi KaNMERA}

\begin{abstract}
The Middle Permian Kozaki formation of the Kuma massif consists of black slate with intertongues of conglomerate in its lower part and with some alternating thin sandstone and siltstone in its upper part. Intercalated in slate, rarely in conglomerate, of the lower subformation are small lenses of black to dark-grey bioclastic limestone at several horizons, which carry rich fusulines comprising Misellina, Neoschwagerina, Cancellina, Verbeekina, Pseudodoliolina, Nankinella, Sphaerulina, Minojapanella, Yangchienia, Schubertella, Toriyamaia, Schwagerina, Nagatoella and Parafusulina. Two distinct faunules, the lower, Misellina claudiae faunule, and the upper, Neoschwagerina simplex faunule, are recognized in the lower part. These faunules provide a valid basis for accurate zonation and correlation of the lower Middle Permian in Japan and related provinces, and the strata characterized by these faunules are nearly contemporaneous with the Pseudofusulina ambigua zone and the Parafusulina kaerimizensis zone, respectively. The $N$. simplex faunule well defines the lowest part of the so-called Neoschwagerina zone.
\end{abstract}

\section{Contents}

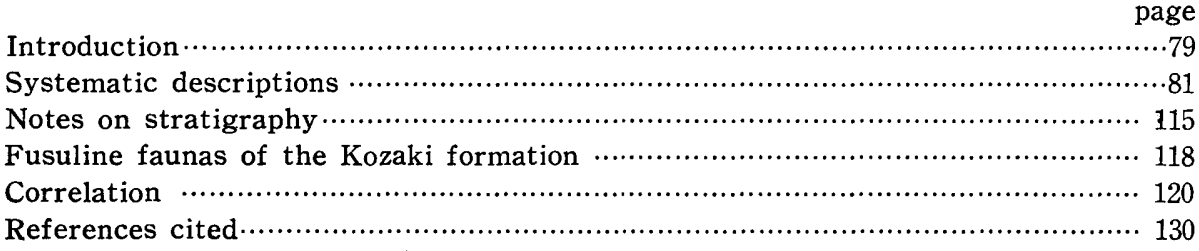

\section{Introduction}

The workable zonal subdivision of the Middle Permian of the Japanese Islands was at first established by Ozawa (1927) in the Akasaka Limestone mainly on the basis of abundant neoschwagerinids. OzawA's scheme** comprises the zones of Cancellina nipponica $(\mathrm{Nn})$, Neoschwagerina craticulifera $(\mathrm{Nc}), N$. margaritae $(\mathrm{Nm})$ and Yabeina globosa $(\mathrm{Ng})$, in ascending order, each of which is defined by a characteristic assemblage of fusuline species.

* Received October 15, 1962

** The Akasaka research group (1956) and Hovso (1959), who restudied the fusulines of the Akasaka Limestone, ascertained that OzawA's zonal scheme can be principally warranted, although minor revisions should be added. 
Since the establishment of this scheme the upper three zones have proved to extend widely to many other areas of Japan, but the lowest zone is the least known elsewhere outside Akasaka on account of sparse and separated occurrence of the zone fossil, Cancellina nipponica, and other associated species. In connection with this a problem which should be settled on the Permian biostratigraphy in Japan is the relation between the so-called Neoschwagerina zone and the so-called Parafusulina zone, about which several controversial opinions have been presented.

The Kozaki formation of the Kuma massif, southern Kyushu, the western extremity of the Chichibu Terrain of the Outer Zone of Southwest Japan, contains in its lower part two distinct faunules which can be called in ascending order the $\mathrm{Mi}$ sellina claudiae faunule and the Neoschwagerina simplex faunule. These faunules include species which serve as widely applicable indices for zonation of the lower part of the Middle Permian in Japan. In other words, they work as a good basis for the solution of the problem mentioned above. They, furthermore, provide a valid material for interregional correlation of the Japanese Middle Permian formations with those of Sikhote-Alin, South China, Pamir, Afghanistan, Crimea, Montenegro and also of Mexico and Guatemala.

This paper presents the descriptions of the fusulines contained in the lower part of the Kozaki formation with a brief note on the stratigraphic sequence and remarks on the biostratigraphic significance of the fauna.

Repository. - The collections and type-specimens are kept in the Department of Geology, Faculty of Science, Kyushu University. The register numbers for the typespecimens of the new species are indicated in the systematic portion of respective species and also in the plate explanations, and those of other species are given in the plate explanations.

Measuring terms. - Height of volutions that is given in the systematic description and the accompanying tables is the height from the bottom of a given volution to that of the succeeding volution, that is, from the upper surface of the spirotheca of the preceding volution to that of a given volution. In sagittal sections it can be precisely determined, for the beginning and ending of each volution can be seen. In axial sections - necessarily well centered and oriented - it is measured in the central part of a shell; in the inner two or three volutions the height of a given volution varies greatly for the position of the slice, but we can assume the nearly correct height of each volution from the characters seen in the axial section. If the section had been at $\frac{1}{4}, 1 \frac{1}{4}, 2 \frac{1}{4}$ volution ……... on one side of a specimen, and at $\frac{3}{4}, 1 \frac{3}{4}, 2 \frac{3}{4}$ volution $\cdots \cdots \cdots \cdots \cdot \ldots$ on the other side, the heights of the first, second volution $\cdots \cdots \cdots \cdot \cdots$ are given respectively as the intermediate between the heights of the $\frac{3}{4}$ th and $1 \frac{1}{4}$ th volutions, of the $1 \frac{3}{4}$ th and $2 \frac{1}{4}$ th volutions, and so on. In the mature stage the height of volutions generally does not vary for the position of the slice so greatly as in the immature stages. Accordingly in practice the largest measurement at a given volution is adopted.

Measuring methods on other features are the same as those by most workers on fusulines.

Acknowledgements. - This work is one of the results of my biostratigraphical study on the Palaeozoic rocks of the Kuma massif that has been carried on at the suggestion of Professor Tatsuro Matsumoto. I wish to express my cordial thanks to him 
for his invaluable advice in many respects. I acknowledge with gratitude my indebtedness to Professor Ryuzo ToRIYAMa for allowing me free use of his personal library and giving me instructive advice on the systematic problems. My thanks go also to Miss Mitsué Ishikawa for drawing text-figures and to Miss Chizuko Okamura for typing the manuscript.

The field work was made possible by grants from the Ministry of Education.

\section{Systematic Description}

Family Fusulinidae MöLLER, 1878

Subfamily Staffellininae M.-MACLAY, 1949

Genus Nankinella LEE, 1933

Type-species. -Staffella discoides LEE, 1931

Synonymy. - Hayasakaina Fưrmoto and KaWADA, 1953

Remarks. -Eleven species of Nankinella, of which nine are unnamed, have been recorded from Japan. In addition two species including the type-species that were originally described under the name Hayasakaina are, in my opinion (KANMERA, 1958), also included in Nankinella. The middle Permian examples of the genus are represented by $N$. discoides (LEE) identified by HANZAW A (1950) from the Hatanosawa Limestone of the Kitakami massif, $N$. kotakiensis (FuJImoto and KAwaDA) described by IGo(1956) from the Osobudani conglomerate of the Hida massif, and $N$. sp. forma A recorded by ToRIYAMA (1958) from the Akiyoshi Limestone. One more species is described below as a new species from the Kozaki formation.

Nankinella kozakiensis sp. nov.

Pl.11, figs. 14-21; Pl.12, figs. 5-7

Material. - This species is based on a number of sectioned or polished specimens. Holotype, GKD 12151 a (Pl. 11, fig. 14); paratypes, GKD 12155 a (Pl. 11, fig. 15); 12143 (Pl. 11, fig. 16); 12144a (Pl.11, fig. 17); 12152 (Pl.11, fig. 18); 12146a (Pl.11, fig. 19); 12157 (Pl.11, fig. 20); 12160 (Pl.11, fig. 21); 12142 (Pl.12, fig. 5); 12137 (P1 12, fig. 7).

In most specimens the central and axial parts of the shell are so largely replaced by secondary mineralization that the microscopic structures are often obliterated. The shape and size of the shell, the thickness of the spirotheca, etc. can be examined fairly enough also in the polished specimens.

Description.-Shell thick, discoidal, with narrowly angular periphery, straight to slightly convex lateral slopes, and straight axis of coiling. Poles seem to be not umbilicate. Shape of shell almost uniform throughout most part of growth, but in outer volutions shell becomes gradually narrower laterally and the last volution of mature specimens has a sharply angular periphery which is more or less shifted from the planispiral plane of preceding volutions. No uncoiled part developed.

Mature specimens of $6 \frac{1}{2}-7$ volutions 1.1 to $1.4 \mathrm{~mm}$ long and 2.1 to $2.5 \mathrm{~mm}$ wide giving form ratios of 0.55 to 0.65 . Form ratios of first to sixth volution of holotype $0.66,0.65,0.61,0.60,0.58$, and 0.57 , respectively. Those of a paratype (GKD $12152, \mathrm{Pl} .11$, fig. 18) $0.66,0.64,0.59,0.59,0.59$, and 0.56 , respectively. 
Secondary mineralization has so largely destroyed minute structures of central part of shell that the range in size of proloculus can not be determined. However, outside diameter of proloculus of holotype measures about 100 microns, and that of a paratype (GKD 12140) 96 microns. Heights of first to sixth volution of holotype $60,100,123,170,225$, and 266 microns, respectively. Those of first to seventh volution of 4 paratypes $64-70,82-112,128-160,160-226,242-258$, and 242-258 microns, respectively. Heights of chambers in outer volutions of other paratypes are similar to the above measurements. Chambers highest over the tunnel, and decrease rapidly in height polewards.

Spirotheca relatively thick; its structure can not be determined due to secondary mineralization. Thickness of spirotheca of second to sixth volution of holotype 20 , 26, 32, 40, and 44 microns, respectively. That of third to sixth volution of 3 paratypes ranges between 22 and 32,32 and 44,35 and 40 , and 35 and 40 microns, respectively.

Septa closely spaced, and distinctly arcuate anteriorly. Septal counts of third to fifth volution of a paratype (GKD 12146a, Pl.11, fig. 19) 17, 21, and 23, respectively. That of fifth volution of another paratype 26 . Septa unfluted throughout length of shell.

Tunnel narrow, low; its path straight. Tunnel angles in third and fourth volution of holotype and several figured paratypes range between 15 and 20 degrees. Chomata well developed throughout shell; asymmetrical in cross-section; their tunnel sides generally steep, and their poleward slopes low. Chomata of inner volutions often extend to polar regions.

Remarks. - The present species is most similar in the general shell-shape and size to Nankinella terebra (LANGE) from the Middle Permian of Guguk Bulat, Sumatra, but it has a much loosely coiled shell; the height of its outer volutions exceeds 240 microns in most specimens, whereas that of the last volution of the latter given by LANGE is 180 microns. The proloculi of the Kozaki specimens seem to be much larger than those of the Sumatran ones.

The present species somewhat resembles Nankinella orbicularia LEE from the Chihsia Limestone and equivalents (LeE, 1934; Chen, 1934; Sheng, 1956) in its shell shape, but differs in its much smaller size and in having fewer volutions at maturity.

It is also similar to "Ozawainella" hunanensis CHEN from the Maok'ou Limestone of Southern China, but differs in its smaller shell with fewer volutions. In the size and shape of the shell it also shows a resemblance to Nankinella ovata M. -MAclay described from Crimea, but it can be distinguished by its thicker spirotheca and better developed chomata.

Occurrence-Abundant in the lowest limestone member b at loc. Km. 5004, h; Kozaki-dani. Associated species are listed in Table 8.

\section{Genus Sphaerulina LEE}

Type-species. - Sphaerulina crassispira LEE, 1933

Remarks. - This genus is monotypic and the type-species was originally described from Kwangsi, China. Two other records of the occurrence of the genus outside China are, so far as I know, of the same species identified by Hanzawa (1950) from the Middle (?) Permian at the Choshi Head, about $100 \mathrm{Km}$ east of Tokyo and $S$. 
crassispira caucasica M.-MAcLAy from the Lower Permian of Caucasus. It seems to me, however, that the Choshi specimens are not referable to $S$. crassispira in having a thicker spirotheca for the corresponding volutions and a more rapid expansion of the shell in the inner volutions.

The structure of the spirotheca of $S$. crassispira has not been determined with certainty. Although the shell of the same species described below has also been greatly suffered from secondary mineralization, some of the specimens demonstrate the same structure as stated by LEE (1933) on the spirotheca of the type-specimens.

\section{Sphaerulina crassispira LEE}

P1. 12, figs. 13-29; P1. 19, figs. 10-12

1933. Sphaerulina crassispira LEE, Mem. Nat. Research Inst. Geol. no. 14, p. 17, pl. 1, figs. 2-2a, 3a.

1959. Sphaerulina crassispira caucasica M. -MaclaY*, Osnovi Paleontologii, Academii Nauk, Compare. p. 207, pl. 4, fig. 4.

1950. Sphaerulina crassispira, HanzaWA, Short Papers, Inst. Geol. Palaeont. Tohoku Univ., no. 2 , p. $5-7$, pl. 1 , figs. $4-8$.

Holotype. - The specimen illustrated by LEE as fig. $2 \mathrm{~b}^{* *}$ of pl. 1, designated by Thompson (1948, p. 31).

Specific diagnosis. -See LEE, 1933, p. 17.

Remarks. - The Kozaki specimens described below can be subspecifically distinguished from the typical form of $S$. crassispira. They always have a larger shell than the Chinese type-specimens as indicated by graphs (Figs. 1a, b). Although no comment can be given on the Caucasian form, subspecific separation is established as follows:

a) Sphaerulina crassispira crassispira LEE

Holotype: Indicated above

b) Sphaerulina crassispira caucasica M.-MACLAY

c) Sphaerulina crassispira japonica subsp. nov.

Sphaerulina crassispira japonica subsp. nov.

Material. -Holotype of the subspecies, GKD 12206 (Pl. 12, fig. 14) from loc. 7584b, in Éri-dani. Paratypes, GKD 12213(Pl. 12, fig. 13); 12212, (Pl. 12, fig. 15); 12209, a (Pl. 12, fig. 16); 12261 (Pl. 12, fig. 17); 12202 (Pl. 12, fig. 23); 12209, b (Pl. 12, fig. 26) from loc. $\mathrm{Km} \mathrm{7584,} \mathrm{b} \mathrm{(b} \mathrm{member)} \mathrm{in} \mathrm{Eri-dani:} \mathrm{12271.} \mathrm{a} \mathrm{(Pl.} \mathrm{12,} \mathrm{fig.} \mathrm{21),} \mathrm{12271,} \mathrm{b}$ (P1. 12, fig. 25) from loc. $\mathrm{Km} 7584$ (b member) in Eri-dani: 12144, b (Pl. 12, fig. 18); 12165, a (Pl. 12, fig. 19); 12167 (P1. 12, fig. 20), 12169 (Pl. 12, fig. 22); 12165, b (Pl. 12. fig. 24); 12168 (Pl. 12, fig. 27) from loc. Km 5004, j (b member) in Kozaki-dani, Sakamoto-mura. In addition to the holotype and illustrated paratypes, a number of other specimens have been studied. All the specimens are to some or great extent replaced by secondary mineralization.

Description. - Shell subspherical, planispiral throughout growth, having short axis of coiling, broadly rounded periphery, and almost flat to slightly convex polar areas.

* I have had no opportunity to refer the original description of this subspecies (M. -MACLAY, 1957)

** Misprinted as fig. 3b in Thompson's original designation (1948, p. 31). 
Mature shells of $8-9 \frac{1}{2}$ volutions 1.7 to $2.2 \mathrm{~mm}$ long and 2.0 to $2.8 \mathrm{~mm}$ wide, giving form ratios of 0.8 to 0.9 .

Proloculus minute, spherical; its outside diameter ranges from 110 to $144 \mathrm{mic}-$ rons. First 2 volutions distinctly discoidal with rather narrowly rounded periphery and convex polar ends, and their form ratios 0.5 to 0.65 . Beyond third volution periphery is broadly rounded and polar areas become gently convex, the shell attaining a subspherical shape. Heights of first to tenth volution of holotype 60 (?), 80 , 88, 96, 112, 128, 144, 168, 194, and 194 (?) microns, respectively. Shell expands slowly and uniformly. In paratypes very similar or the same measurements are given for corresponding volutions (see Table 1). Chambers almost equal in height throughout length of shell.

Due to secondary mineralization of shell, the spirothecal structure has been largely obliterated. So far as is seen, however, the spirotheca is composed of a thin upper layer and a thick lower layer which shows a distinct fibrous structure (see PI. 12, figs. 28, 29). In relatively well preserved specimens, the upper layer is recognizable as a very thin, dark, dense layer like the tectum of other fusuline genera. The lower layer consists of closely arranged, very fine and parallel pillar-like prismatic crystals of clear calcite oriented normal to the upper layer. It is certain that these calcite prisms are the product by the secondary mineralization, and their arrangement suggests that they have been made intimately followed the original structure of the spirotheca. They are almost the same in width (mostly 4-5 microns) throughout their length, and the suture lines between the pillars are seen as very thin dark lines as those in the keriotheca of the spirotheca of the Verbeekininae, and are never so distinct as in those of the Schwagerininae and Neoschwagerininae. The calcite pillars end against the upper layer of the spirotheca, but in rare cases they seem to be continued by mineral growth into the upper layer and also into the overlying chomata. So far as the Kozaki specimens are concerned, the spirotheca is most likely to that of Verbeekina. The lower surface of the spirotheca is covered with an extremely thin dark layer in some parts.

Spirotheca thickest in equatorial area and gradually thins towards poles. Due to secondary mineralization, it is often difficult to measure exact thickness of spirotheca, but the thickness obtained for first to eighth volution in many specimens is $10-12,12-16,16-24,20-24,27-29,31-34,36-41$, and 49 microns, respectively.

Septa plane throughout length of shell and extend anteriorly at a small angle from normal to spirotheca. Septa rather widely spaced; septal counts obtained are given in Table 1 . They are so completely recrystallized that their structure can not be known.

Tunnel singular, developed throughout growth of shell; its path usually irregular. Tunnel angle 18 to 23 degrees in fourth to seventh volution. Chomata well developed; their tunnel sides steep and slope sides very gentle.

Remarks. - In all the important characters this form can be specifically included in Sphaerulina crassispira. The distinction between this form and the typical form is seen only in that the former is much larger than the latter in the mature stage (see Fig. 1a). However, in the young stage the size and the rate of growth of the Kozaki specimens are nearly equal as those (measurements obtained from the original figures) of the Chinese types. In the succeeding stages the shells of the Kozaki form expand always much more rapidly than those of the Chinese form. This is clearly indicated by a graph (Fig. 1,b) which shows two groups of deviating 

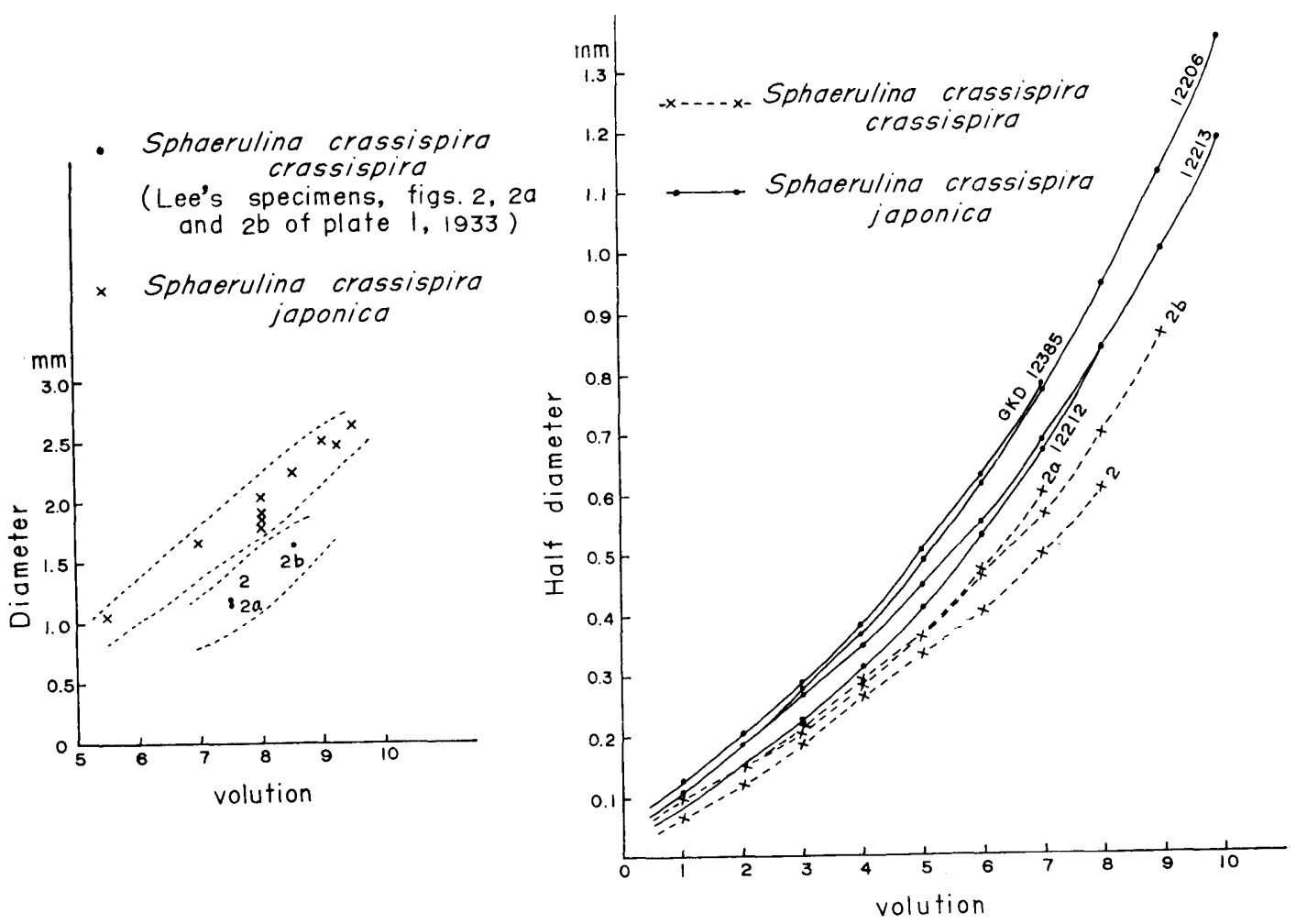

Fig. 1a. Diagram showing the size distribution of the diameter of Sphaerulina crassispira crassispira LEE and $S$. crassispira japonica subsp. nov.

Fig. 1b. Diagram showing the rate of growth in Sphaerulina crassispira crassispira LEE and $S$. crassispira japonica subsp. nov.

curves.

S. crassispira described by Hanzawa (1950) from Choshi, east of Tokyo, is distinguished from the typical subspecies and this new subspecies in having a smaller shell, fewer whorls, a thicker spirotheca for the corresponding volutions, and fewer discoidal whorls in the young stage.

Occurrence.-Abundant in the lowest limestone member b; loc. 5004, $\mathrm{j}$ in Kozaki-dani, and loc. 7584, in Eri-dani. See Table 8 for the associated species.

Subfamily Boultoniinae Skinner and WILdE, 1954

Genus Minojapanella Fummoto and Kanuma, 1953

Type-species. - Minojapanella elongata Fujimoto and Kanuma, 1953

Remarks. -This genus was clearly defined by Fujimoto and KANUMA (1953) and Thompson (1954), and its systematic position was discussed by SKINNER and WildE (1954). In addition to the type-species two unnamed species of the genus have been recorded, one is from the Ibukiyama Limestone of central Japan (KoBAYASHI, 1958) and the other from Montenegro (Kochansky-Devidé, 1958). The former occurs in association with Pseudofusulina sp. and Schubertella sp., and is considered as being 
of Lower Permian age, and the latter with Neoschwagerina bukowskii, N. craticulifera, Verbeekina verbeeki, etc., being of lower Middle Permian age.

As was already pointed out by MorikawA and Isom (1961), there is another species to be included in this genus, which was illustrated by OzAwA (1925, pl. 38, figs. 1b, 13c, without description) as Neofusulinella sp. from the Akasaka Limestone. On examining the specimens I have recognized that they are confidently referable to this genus and belong to one and the same species. The specimens illustrated as fig. 1b of pl. 38 came from the "Kasumi limestone", and are associated with Pseudofusulina ambigua, Codonofusiella sp., and Schubertella sp., and that of fig. 13b of the same plate is of the "Lower Kasumi limestone" and occurs together with Cancellina nipponica (Honjo's Minoella), Pseudofusulina ambigua, P. granum-avenae, Yangchienia compressa, and Schubertella giraudi, being of OzAwA's Nn zone. These specimens closely resemble Minojapanella elongata, but precise comparison between them can not be made because of insufficiency of the material.

A questionable new species is added to this genus from the Kozaki formation as described below.

Minojapanella sp. nov. (?)

Pl. 12, figs. 1-4

Material. -Fifteen sectioned-specimens are referable to this species, but none of them is well-oriented. They may probably represent a new species, but the material is not enough to erect it. Some examples are illustrated: GKD 12415 (Pl. 12, fig. 1), 12426 (Pl. 12, fig. 2), 12403 (Pl. 12, fig. 3), 12401 (Pl. 12, fig. 4); All from loc. Km 5209 (probably b member) in Uminoura, Tanoura-mura. Few other specimens referable

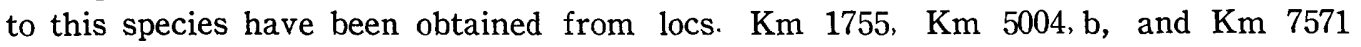
(b member) in Kozaki-dani.

Description. - Shell small, elongate subcylindrical; with a form ratio of larger than 6. 0. Mature specimens of at least 8 volutions 0.8 to $1.1 \mathrm{~mm}$ in width. A diagonally sectioned specimen of $5 \frac{1}{2}$ volutions (Pl. 12, fig. 1) is $0.48 \mathrm{~mm}$ in width and has a minute proloculus of 25 to 45 microns in its outside diameter. Heights of first to sixth $\left(5 \frac{1}{2}\right.$ th) volution of the specimen $14,16,25,41,70$, and 74 microns, respectively. First volution is coiled with an axis which is at a large angle to that of later volutions, and in third volution the axis of coiling becomes greatly extended. Chambers increase gradually in height towards polar ends.

Spirotheca extremely thin and seems to consist of a tectum and a lower transparent layer-diaphanotheca. In some specimens it measures 8 microns in third and fourth volutions, 12 microns in sixth and seventh, and 16 microns in probably ninth.

Septa closely spaced, intensely fluted throughout shell. Fluting extends nearly to top of chambers even in central part of shell. Septal counts of probably fifth to eighth volution of one specimen $31,35,40$, and 42 , respectively, and those of probably sixth to ninth volution in another specimen $37,40,46$, and 47 , respectively.

Tunnel low, narrow, bounded by distinct chomata in inner 4 volutions, but not well defined in outer volutions. Tunnel angle 29 degrees in fourth volution. Chomata narrow, high, and symmetrical in cross-section.

Remarks. - This species differs from $M$. elongata in its much larger shell with more numerous volutions, but the size of the shell, the heights of the corresponding volutions, and the thickness of the spirotheca in the inner five volutions of one 
specimen (Pl.12, fig. 1) well agree with those of the holotype and paratypes of $M$. elongata. $M$. elongata has been found in association with Pseudofusulina krotowi, $P$. vulgaris, $P$. globosa, Triticites sp. etc., and is of Lower Permian age. Whereas the Kozaki specimens are associated with Parafusulina nakamigawai, Misellina claudiae and other species indicated in the columns of loc. $\mathrm{Km} 1755$ and 5004, b of Table 8. Their stratigraphic horizon is higher than the Pseudofusulina vulgaris zone (refer Table 9). They may be a direct descendant of $M$. elongata.

The Kozaki specimens are also distinguishable from Minojapanella sp. described from Montenegro (Kochansky-Devidé, 1958) in having a larger shell, but the material of both species are not enough for the precise comparison.

Occurrence. - Not uncommon in the limestone of loc. $\mathrm{Km} \mathrm{5209}$, and rarely found at locs. $\mathrm{Km} \mathrm{5004,} \mathrm{b}$ and 1755 of the lowest limestone member b, and $\mathrm{Km} 7571$ of the $\mathrm{d}$ member. Associated species are shown in Table 8.

\section{Subfamily Ozawainellinae Thompson and Foster, 1937}

Genus Toriyamaia KANMERA, 1956

Type-species. -Toriyamaia laxiseptata KANMERA, 1956

Diagnosis. -See Kanmera, 1956, p. 262

Remarks. -This genus was established for the monotypic type-species obtained from the Kozaki formation. The generic diagnosis and the relation to other genera were given in my previous paper (KANMERA, 1956, p. 262).

Another example of the genus is the species illustrated under the name Rauserella ? sp. from the Parafusulina sapperi zone of the Ibukiyama Limestone of central Japan (KовAYASHI, 1956, pl. 32, figs. 10-12; 1957, pl. 1, figs. 29, 30). It is undoubtedly referable to Toriyamaia and is probably identical with the type-species of the genus. The general structure of Rauserella sp. from the Parafusulina kaerimizensis zone of the Ikadaba Limestone of Yamaguchi Prefecture (KawaNo, 1961, p. 58, pl. 1, fig. 1) demonstrates that the species is probably referable to Toriyamaia. Furthermore three syntypes of Biwaella ominensis MorikawA and Isomi (1961, p. 89. pl. 1, fig. 14, 15, ?16) from the Pseudofusulina kraffti zone and the Cancellina nipponica zone of the area near Lake Biwa may be referable to this genus. They are quite different from the remaining specimens including the holotype of the species in the general shape and in having unfluted septa, and they are much similar to Toriyamaia.

Recently SUYARI (1962) illustrated an unnamed species of Toriyamaia from the Kusuné formation of Tokushima Prefecture, but no description has been given.

\section{Toriyamaia laxiseptata KANMERA}

$$
\text { Pl.11, figs. 1-4; P1.19, figs. 8, } 9 .
$$

1956. Rauserella? sp. Kobayashi, Trans. Proc. Palaeont. Soc. Japan, N. S., no. 23, p. 227 , pl. 32 , figs. $10-12$.

1956. Toriyamaia laxiseptata $\mathrm{K}_{\mathrm{ANMERA}}$, Ibid., no. 24 , p. $252-255$, pl. 36 , figs. 1-14.

1957. Rauserella? sp., Kobayashi, Sci. Rep. Tokyo Kyoiku Daigaku, Sect. C, no. 48, (illustration only), pl. 1 , figs. 29,30 . 
Types. - Holotype, GKD 10201 (Kanmera, 1956, pl. 36, fig. 1); Paratypes GKD 10202-10214, of which the specimens of GKD 10202, 10203, and 10211 are reproduced here for the sake of better understanding.

Remarks. - No additional comment is needed at present to the specific diagnosis and description of this species already given in my previous paper.

The type specimens were originally found in a limestone cobble of a conglomerate of the Kozaki formation exposed at a railroad cut in Uminoura, Tanoura-mura. The identical specimens were also obtained from limestone lenses (loc. Km 5004, d, j) of the member $b$ of the lower subformation of the Kozaki formation in the type area. They are associated with Misellina claudiae, Nagatoella sp., Pseudofusulina sp., Nankinella japonica, Sphaerulina kozakiensis, and Schubertella giraudi.

The Ibukiyama specimens are incomplete, but they are quite identical with the type specimens in important structures. Their stratigraphical horizon is also almost equivalent.

Subfamily Schubertellinae SkINNER, 1931

Genus Schubertella StafF and WedeKInd, 1910

Type-species. - Schubertella transitoria STAFF and WEDEKIND, 1910

Synonymy. - Depratella OzAwA, 1928

Diagnosis. -See Thompson, 1948, p. 48

Remarks. -OzAwa (1928) proposed the genus Depratella with Neofusulinella giraudi DePRAT as the type-species, but THOMPSON (1937) regarded it as a synonymy of Schubertella. I have had no opportunity to examine the types of this species, but so far as Ozawa's hypotypes of this species $(1927$, p. 150, pl. 38, figs. 3-6, 9, 16c; pl. 39, figs. 4-6) from the Nn zone of the Akasaka Limestone are concerned, the species is safely referable to Schubertella.

In Japan nine named and one unnamed species of Schubertella has so far been recorded. In addition one named and two unnamed species have been referred to this genus with question. The Middle Permian examples are S. simplex (LANGE) from the Nn zone and $S$. giraudi (DePrat) and $S$. phairayensis (ColanI) from the $\mathrm{Nn}$ and Nc zones. These species have a thick and short fusiform shell with pointed polar ends and are distinctive from the Lower Permian species of the genus, most of which have an elongate fusiform to an elongate subcylindrical shell.

\section{Schubertella giraudi (DEPRAT)}

P1. 12, figs. $8-12$

1915. Neofusulinella giraudi Deprat, Mem. Serv. Geol. I'Indochine, vol. 4, fasc. 1, p. 11-12, pl. 1, figs. 6-11, text-fig. 5 .

1927. Neofusulinella giraudi, Ozawa, Jour. Fac. Sci., Imp. Univ. Tokyo, Sect. II, vol. 2, pt. 3, p. 150-151, pl. 38, figs. 3-6, 9, 16c; pl. 39, figs. 4-6.

1957. Schubertella giraudi, KobayashI, Sci. Rep. Tokyo Kyoiku Daigaku, Sect. C, no. 48 , p. $263-264$, pl. 1 , figs. $1-5$.

Types.-DEPRAT (1915) established this species on at least four syntypes. The figured specimen of an axial section [DEPRAT, 1915, pl. 1, fig. 6(=7, enlarged figure of fig. 6) ] should be designated as the lectotype, but as I have not seen the 
actual specimens of the syntypes, I hesitate to give here a designation.

Material. -A number of sectioned specimens are referable to this species, but none of them was well oriented. For the sake of comparison several better sectioned specimens are illustrated. The following descriptions are entirely based on the Kozaki specimens.

Description. - Shell minute, inflated biconical; with pointed poles and slightly convex to straight lateral slopes. Largest specimen of probably 5 volutions measures $1.35 \mathrm{~mm}$ in length and $0.62 \mathrm{~mm}$ in width. Most specimens of $4 \frac{1}{2}$ volutions 1.0 to $1.1 \mathrm{~mm}$ long and 0.6 to $0.65 \mathrm{~mm}$ wide, giving form ratios of 1.6 to 1.8 . Proloculus nearly constant in size in examined specimens, being 32 to 40 microns in its outside diameter. First volution has a short axis of coiling, but shells change their axis in second volution at angles as great as $90^{\circ}$ to that of first one and attains a long axis. Shell expands rapidly, and heights of first to fourth volution of 5 specimens 28-32, $32-45,56-64$, and 96-112 microns, respectively.

Spirotheca seems to consist of a single dense layer in inner $1 \frac{1}{2}$ volutions, but beyond second volution it is composed of a tectum and a lower clear layer-diaphanotheca. In central part of shell upper surface of tectum is often coated with a dense deposit which is continuous with chomata. Lower surface of diaphanotheca is sometimes lined with the same deposit. Thickness of spirotheca can not be measured exactly in inner volutions, but combined thickness of tectum and diaphanotheca in outer volutions is 16 to 20 microns.

Septa very thin, except near chomata where they are thickly covered with dense deposits mentioned above. Septal count 13-15 in third, and 17-18 in fourth volution in 4 specimens. Septa plane throughout shell except in extreme polar ends where they are slightly undulated in outer volutions.

Chomata well developed in second to outer volutions; asymmetrical in crosssection; its path almost straight; their tunnel sides almost vertical, and poleward slopes usually steep, occasionally extending to poles. Tunnel relatively wide, high for the size of shell; tunnel angles of third and fourth volutions range from 30 to 35 degrees.

Remarks. - This species was originally described under the genus Neofusulinella, but Thompson and Foster (1937) and Thompson (1948) have suggested that it may be referable to Schubertella. So far as OzawA's specimen of $N$. giraudi and the Kozaki specimens described above are concerned, the essential shell structures well agree with those of the type-species of Schubertella.

The Kozaki specimens so well resemble Deprat's types of this species in many important characters that specific identity is undoubted. DePrat $(1915$, p. 12) gave $0.013 \mathrm{~mm}$ for the proloculus diameter of one of the types (pl. 1, fig. 10), but as far as is seen in the original figure, no great difference in the proloculus size between the types and the Kozaki specimens can be recognized.

This species resembles $S$. simp'ex LANGE from Sumatra in a general shell-shape, but it is larger and has a thinner spirotheca and more prominent chomata.

Ozawa (1927) referred Neofusulinella praecusor pusilla Colani to this species as a synonymy, but the former has fewer septa for the corresponding volutions, being probably a different species from the latter.

Occurrence. - Common in the lowest limestone member (b), locs. 5004 h, 5004 g; rare in the upper limestone members $d$, e, and $f$, locs. 1696, 5007, 7566; all in Kozakidani. 
Genus Yangchienia LEE, 1933

Type-species. - Yangchienia iniqua LEE, 1933

Diagnosis. - Refer Thompson, 1948, p. 35-36

Remarks. - Three species of Yangchienia have been known so far in Japan, the first is $Y$. compressa (OzAwa, 1927) from the Cancellina nipponica zone of the Akasaka Limestone, the second is $Y$. sp. described by SAKAGAm (1958) from the Upper Permian Yamanouchi conglomerate of the Kwanto massif, and the third is $Y$. sp. by Morikawa and Isomi (1961) from the Kusanogawa and Onogi formations, and the lower part of the Ibukiyama Limestone in central Japan. The second is easily distinguished from the other two and is, according to SAKAGAMI, associated with Neoschwagerina margaritae DEPRAT in a limestone boulder of the conglomerate. The third is probably identical with $Y$. compressa and belongs to completely or nearly the same zone as the Nn zone. Fusulinella itoi Ozawa which was once referred by Thompson (1935) with a query to Yangchienia and later to Neofusulinella (1946, 1948) has been proved by ToriYama (1958) to be a true Fusulinella of the Fusulinella zone.

\section{Yangchienia compressa (OzAWA)}

Pl. 11, figs. $5-13$

1927. Fusulinella compressa Ozawa, Jour. Fac. Sci., Imp. Univ. Tokyo, Sect. II, vol. 2, no. 3 , p. $142-143$, pl. 37 , fig. 6 ; pl. 38 , figs. $2 \mathrm{~b}, 10,13 \mathrm{~b}, 16 \mathrm{~b}$; pl. 39 , figs. 3,7 .

1935. Yangchienia compressa, Thompson, Eclogae Geol. Helvetiae, vol. 28, p. 514, 516.

? 1936. Fusulinella compressa, Huziмoтo, Sci. Rep. Tokyo Bunrika Daigaku, Sect. C, vol. 1, no. 2, p. 40-41, pl. 2, fig. 9.

1957. Yangchienia cf. compressa, KовауаянI, Sci. Rep. Tokyo Kyoiku Daigaku, Sect. C, no. 48 , p. $265-266$, pl. 1 , fig. 17.

? 1957. Schubertella phairayensis, KовауаsHI, Ibid., p. 260-261, pl. 1, figs. 9, 10.

1961. Yangchienia sp., Morikawa and Isomi, Report, Geol. Survey of Japan, No. 191, p. 8 , pl. 9, figs. $12-14$.

Types.-Ozawa (1927) erected this species on several syntypes, of which the figured axial section (pl. 39, fig. 7) is here designated as the lectotype. (The types are kept in the Department of Geology, Tokyo University).

Material.-More than twenty specimens are referable to this species, but only a few of them are well oriented. Some specimens are illustrated. I have examined OzAwA's original specimens of this species, with which the Kozaki specimens were directly compared.

Description. - Shell of this small fusiform species of $6-6-\frac{1}{2}$ volutions 2.2 to $2.9 \mathrm{~mm}$ long and 0.98 to $1.2 \mathrm{~mm}$ wide, giving form ratios of 2.25 to 2.45 . Largest specimen obtained of 9 volutions attains $1.37 \mathrm{~mm}$ in width. Poles pointed; lateral slopes usually gently convex, but in some specimens slightly concave near poles in outer volutions.

Proloculus attains 64 to 80 microns in its outside diameter. First volution has a short axis of coiling which is at an angle as large as $90^{\circ}$ to that of later volutions. Shell expands slowly and uniformly. In a typical specimen (Pl.11, fig. 5) heights of first to sixth volution $40,48,50,72,88$, and 128 microns, respectively, and form ratios of the same volutions $0.7,1.5,1.8,1.9,2.39$, and 2.32 , respectively. In another specimen heights of first to sixth volution $32,43,56,88,112$, and 128 microns, 
respectively.

Spirotheca very thin, composed essentially of a tectum and a lower transparent layer-diaphanotheca. In the inner volutions the diaphanotheca is extremely thin and is often indiscernible from the matrix by secondary mineralization. The lower surface of the diaphanotheca is often coated with a very thin dense layer which is the same in nature as the chomata. The upper surface of the tectum is also covered with the same dense layer, but there often lies a very thin transparent layer between the tectum and the dense deposit of the chomata. In this case the spirotheca seems as if to consist of four layers, that is, the tectum, outer and inner transparent layers partly with a coating of dense deposit. Combined thickness of essential two layers of spirotheca in third to eighth volution in the best preserved specimen (Pl.11, fig. 12) measures $8,10,12,14,15$, and 16 microns, respectively. That of third to sixth volution in other 3 specimens ranges between 8 and 10,10 and 14 (?), 11 and 16 . and 16 and 20 (?) microns, respectively.

Septa comprise downward deflections of spirotheca. Since no well-oriented sagittal section has been obtained, the exact septal count can not be known. However, septal counts in probably third to sixth volution of some specimens 11, 13(?)-17, 19-21, and 24, respectively.

Tunnel high, well bounded by thick chomata; its path and width irregular even in the same volution of one specimen. Chomata very thick, broad, made up of many laminated layers of dense deposit, and in inner volutions they extend to poles.

Remarks. - The spirotheca of the present specimens is entirely the same in structure as that of the lectotype and syntypes of Yangchienia compressa. The same structure of the spirotheca has already been recognized by THOMPSON $(1935,1948)$ in $Y$. tobleri and some other previously known species of the genus.

On examining the types of $Y$. compressa I noticed that the species shows a fairly great variation in the heights of the volutions and in the chomata development. The heights of the first to the sixth volution of the lectotype are $32,40,48,64,80$, and 96 micros, respectively. While the largest heights obtained in one of the syntypes are $32,35,64,96$, and 131 microns, respectively, for the first to the fifth volution. The chomata of the lectotype are a weaker example for the species. For the sake of better understanding of the nature of the chomata one of the syntypes is illustrated (Pl.11, fig. 13), in which the chomata are as strong as in the typespecies of the genus, $Y$. iniqua.

The Kozaki specimens under consideration are quite identical with the types of $Y$. compress $a$ in essential characteristics, and the measurements obtained fall in the variation of the types of the species.

$Y$. compressa is distinct from $Y$. iniqua in its slenderer shell, less prominent chomata in general and fewer, irregularly coiled volutions. The Kozaki specimens are intermediate in shape and chomata development between the types of two species, but are closer to $Y$. compressa.

$Y$. compressa identified by Fujimoto (Huzimoto, 1936) from the Kwanto massif have fewer septa, weaker chomata and more highly biconical inner volutions than the types. They are associated with Pseudofusulina vulgaris (Schellwien), P. krotowi (Schellwien), Triticites parvulus (Schellwien), etc., which are the members of the Pseudofusulina vulgaris subzone, the upper part of the Pseudoschwagerina zone. FujImoto's specimens are probably not conspecific with the species.

Yangchienia sp. illustrated by MoRIKAwA and Isom (1961) with a brief note 
from the Onogi formation and the lower part of the Ibukiyama Limestone of central Japan seems to be more closely related to $Y$. compressa than to $Y$. iniqua in general shape and size and in having less massive chomata.

Six species of Yangchienia have hitherto been known from the Middle Permian of the Tethys region. $Y$. compressa is very similar to $Y$. antiqua Kochansky-Devidé from South Crna Gora (Montenegro) and the difference between them is seen only in that the former has a more elongate shell. The other species from the higher horizons have a more sharply conical shell, and more numerous and more closely coiled whorls than $Y$. compressa.

Occurrence. $-Y$. compressa occurs throughout the four limestone members of the lower subformation of the Kozaki formation, but is most abundant in the e limestone member. See Table 8 for the collecting localities and the associated species.

Subfamily Schwagerininae Dunbar and Henbest, 1930

Genus Nagatoella Thомеson, 1936

Type-species. - Schellwienia ellipsoidalis orientis OzAWA, 1925

Remarks. - The generic diagnosis of this genus was well defined by THompson (1936, 1948). The following five species have been referred to this genus from Japan: $N$. orientis (OzAwA), $N$. kobayashii Thompson (1936), N. fujimotoi Morikawa (1958), $N$. ikenoensis Morikawa and Isomi (1961), and $N$. sp. by Torixama (1958). So far as I am aware, no species of the genus have been found outside Japan, although Triticites ordinatus $\mathrm{CHEN}_{\mathrm{H}}$ and $T$. sinensis $\mathrm{CHEN}_{\mathrm{H}}$ from the lower part of the Swine Limestone are closely related to this genus.

According to Toriyama (1958) N. kobayashii and N. sp. occur from the Pseudofusulina vulgaris zone to the Neoschwagerina craticulifera zone in the Akiyoshi Limestone, but the former species is most abundant in a horizon between the Pseudofusulina ambigua zone and the Parafusulina kaerimizensis zone, occurring in association with Misellina claudiae and Nankinella sp. $N$. orientis is known to occur together with M. claudiae (OzAwA, 1925; Thompson, 1936), and $N$. kobayashii with Parafusulina edoensis OzAwa which is an important member of the P. kaerimizensis zone.

N. fujimotor was recorded to occur with Parafusulina (Skinnerella) japonica and Pseudoschwagerina sp. However, the limestone from which the species came is conglomeratic (Morikawa, 1951), so the exact association with the species can not be confirmed.

A specimen of $N$. aff. $N$. kobayashii illustrated by myself (1956) without description from a limestone cobble of the conglomerate of the Kozaki formation occurs also with Misellina claudiae. A species of the genus described below is confined to the Misellina claudiae zone of the lowest part of the Kozaki formation.

Thus the known species of Nagatoella frequently defines a distinct zone together with $M$. claudiae. However, very recently MoRIKAwA and Isom (1961) described Nagatoella ikenoensis from the Kusanogawa group in the east of Lake Biwa, central Japan. It is associated with Pseudofusulina regularis (ScHellwien) and Misellina ibukiensis KoBayasHI. These species were assigned by them to the Pseudoschwagerina zone. 
Nagatoella sp.

Pl. 14, figs. 22-24; pl. 19, fig. 13

Meterial. - The meterial came from two adjacent limestone lenses of the same horizon. That of loc. $\mathrm{Km} \mathrm{5004,j}$ includes, besides several diagonal and some random oblique sections, two axial sections-GKD 12166, a (P1.14, fig. 22) and 12166, b (P1. 14, fig. 23)-and one sagittal section-GKD 12161 (P1.14, fig. 24). The outer one or two volutions of the axial sections have probably been exfoliated. From loc. $\mathrm{Km}$ 5004, d only one axial section-GKD 12445 (Pl.19, fig. 13) has been obtained

Descriptive remarks. - As is understood from the illustrations of Plates 14 and 19 and the statistical data in Table 2, the three specimens of axial section mentioned above show fairly distinct differences from one another particularly in the shape of the development of chomata. Due to incompleteness and the shell and shortage of the material it is not clear whether they belong to different species or show merely the variation within one and the same species. The detailed descriptions of these specimens are postponed until definite identification can be made on the basis of sufficient materials. So far as is known at present, the specimen of fig. 22 of Plate 14 is similar to $N$. orientis (OzAwA) from the Akiyoshi Limestone, but it has less complete dense deposits in the lateral and axial areas. That of fig. 23 of the same plate approaches $N$. ibukiensis MorikAwA and Isom from the Kusanogawa Group of central Japan. The remaining axial section of fig. 13 of Pl.19 resembles $N$. kobayashii from the Akiyoshi Limestone.

Occurrence. - All the examined specimens have been obtained from the limestone

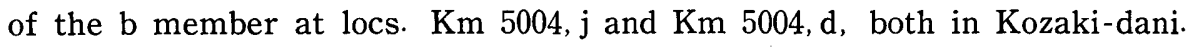

\section{Genus Schwagerina MöLler, 1877}

Type-species. - Borelis princeps EHRENBERG, 1842

Diagnosis and Remarks. -See Dunbar and Skinner, 1936, p. 83-91, and Dunbar, 1958, p. 1019-1021.

\section{Schwagerina? sp. cf. "Pseudofusulina" chihsiaensis (LEE)} P1. 19, fig. 14

\section{Compare. -}

1931. Schellwienia chihsiaensis LeE, Bull. Geol. Soc. China, vol. 10, p. 287-288, pl. 1, figs. 2, 2a.

1934. Pseudofusulina chihsiaensis, CHen, Palaeontologia Sinica, Ser. B, vol. 4, fasc. 2, p. $74-75$, pl. 9 , figs. $1-8,12$; pl. 10, fig. 18 ; pl. 11, fig. 10 ; pl. 14 , figs. 11 12.

1934. P. chihsiaensis var. regularis $\mathrm{C}_{\mathrm{HEN}}$, Ibid., p. 75-76, pl. 9, fig. 10.

1934. P. chihsiaensis var. fragilis CHEN, Ibid., p. 76-77, pl. 9, fig. 11.

1934. P. chihsiaensis var. brevis $\mathrm{C}_{\mathrm{HEN}}$, Ibid., p. 77-78, pl. 9, fig. 9.

1960. Pseudofusulina chihsiaensis, MorikaWa, Sci. Rep. Saitama Univ., Ser. B, Vol. 3, p. 294-295, pl. 46, fig. 16; pl. 52, figs. 1-4.

Lectotype of $P$. chihsiaensis. - In the original description of this species LEE illustrated one axial section and one sagittal section, so naturally the specimen of 
the axial section illustrated as fig. 2 of pl. 1 is designated as the lectotype of $P$. chihsiaensis.

Material. - Only one axial section and a few oblique sections have been obtained. The following description is entirely based on the axial section.

Descriptive remarks. - Shell fusiform with slightly curving axis of coiling and bluntly pointed poles. Lateral slopes slightly convex or concave. Inner 3 to $3 \frac{1}{2}$ volutions tightly coiled; beyond fourth volution shell expands rather rapidly. The specimen of 7 volutions $6.40 \mathrm{~mm}$ long and $2.30 \mathrm{~mm}$ wide, giving a form ratio of 2.8 .

Proloculus small; its outside diameter 154 microns. Heights of first to seventh volution $32,43,80,128,202,242$, and 264 microns, respectively. Form ratios for those volutions $2.3,2.6,2.8,2.9,2.9$, and 2.9 , respectively. Chambers nearly the same in height throughout length of shell.

Spirotheca composed of a tectum and an alveolar keriotheca; alveoli very fine in inner four volutions, beyond fourth they become coarse. Thickness of spirotheca in first to seventh volution $16,29,32,48,54,64$, and 80 microns, respectively. Spirotheca show irregular rogosity.

Septa fluted throughout length of shell. Fluting reaches near top of septa, but rather irregular. Tunnel narrow, but high; tunnel angles in third to sixth volution $28,26,25$, and 28 degrees, respectively. Small chomata present in inner volutions. Dense deposits fill chambers in polar areas in first to sixth volution.

In the shape and size of the shell and the degree and nature of the septal fluting, and in having heavy axial fillings and tightly coiled inner volutions the present specinems almost agrees with "Pseudofusulina" chihsiaensis (LEE). Minor difference is seen in that it has a smaller form ratio than the latter, but the difference is within the extent of variation of the species shown by $C_{H E N}$ (1934). For final identification further materials are needed.

Occurrence. - Rare in a limestone lens of the d member, at loc. $\mathrm{Km} 7571,300 \mathrm{~m}$ north of Kozaki.

Genus Parafusulina Dunbar and Skinner, 1936

\section{Subgenus Parafusulina (Skinnerella) Coogan, 1960}

Type-species. - Parafusulina schucherti Dunbar and Skinner, 1937

Diagnosis. - Shell large, thickly fusiform to elongate fusiform, with a straight axis of coiling, bluntly pointed to narrowly rounded poles, and straight or slightly convex lateral slopes. Proloculus moderate to large. In inner several volutions central half of shell subcylindrical and end one-fourth distinctly conical with rather steep lateral slopes and acute polar ends. Shell expands uniformly but rather rapidly. Septa strongly fluted throughout the shell, and low cuniculi may develop in the outer few volutions. Heavy axial fillings occur in the inner volutions. Phrenothecae may be present.

Remarks. - Skinnerella was originally set up as a subgenus of Parafusulina for "species of Parafusulina characterized by fusiform to elongate fusiform shells and cuniculi in an early stage of development, restricted to the outer few volutions."

Parafusulina originally included diverse species of polyphyletic stocks. The presence of cuniculi essentially indicates an advanced stage of evolutionary development in every phylogenetic stock of the Schwagerininae, but is never confined to species 
of particular forms such as an elongate fusiform or cylindrical shape, as shown, for example, in the type-species of Parafusulina. It is true that the cuniculi are well developed in elongate cylindrical species in general. However, we can observe cuniculi also in highly vaulted, short fusiform species, for instance, Parafusulina? vulgariformis MoRIKAWA. I have actually recognized cuniculi in various forms of advanced schwagerinines which are unlike $P$. wordensis.

Thus the presence of cuniculi can not always be a criterion for the critical distinction among advanced schwagerinines which have been referred to Parafusulina, Pseudofusulina, or Schwagerina.

Coogan referred thirteen species of Parafusulina to P. (Skinnerelia). Of those, the type-species of the subgenus, $P$. (S.) schucherti, and $P$. (S.) diabloensis Dunbar and Skinner, $P$. (S.) australis Thompson and Miller, $P$. (S.) japonica (Gümbel) and $P$. (S. ) yabei HANZAw a have a fusiform shell with heavy axial fillings, and their inner volutions have a thick fusiform with a short cylindrical mid-region, conical lateral sides and acute polar ends. While in $P$. wordensis, the type-species of Parafusulina (Parafusulina), the inner volutions are elongate subcylindrical and has no distinct axial fillings. $P$. rothi Dunbar and Skinner, $P$. virga Thompson and WheELER, $P$. sellardsi $\mathrm{D}$. and S., and $P$. maleyi $\mathrm{D}$. and $\mathrm{S}$. also have the same features. $P$. $(S$.) bakeri D. and S., and $P$. fountaini D. and S. which were assigned by CoogAN to $P$. (Skinnerella) are rather close to $P$. wordensis than to $P$. $(S$.$) schucherti.$

From the facts and the view-point about cuniculi as mentioned above, I would put the stress in distinguishing $P$. (Skinnerella) from $P$. (Parafusulina) on the difference of the shell-shape, especially that of the young stages.

Some species which should be referred to $P$. (Parafusulina), such as $P$. maleyi Dunbar and Skinner, $P$. nancei Thompson and Miller, $P$. durhami $T$. and $M$., have a narrow belt of the axial fillings, but their ontogeny in the young stage show the same features as that of $P$. wordensis.

$P$. (Skinnerlla) is distinguished from Schwagerina in that its shell is more elongate and expands more rapidly in the young stages and more slowly in the mature stage, and its proloculus is smaller.

In Japan Skinnerella occurs most abundantly in the Misellina claudiae and the Neoschwagerina simplex zone, which are equivalent in age to the lower and the upper Leonardian, respectively.

\section{Parafusulina (Skinnerella) gruperaensis (ThOMPson and MILleR)}

P1. 15, figs. 9-13, 14 (?)

1945. Schwagerina gruperaensis Thомpson and Mrller, Jour. Paleont., vol. 18, no. 6, p. 495 , pl. 79 , figs. $1-4$.

1948. Schwagerina? gruperaensis, Thомpson, Univ. Kansas Paleont. Contr., Protoza, art. 1, p. 48, pl. 9, figs. 1,2 .

1960. Schwagerina gruperaensis, KLING, Jour. Paleont., vol. 34, no. 4, p. 468, pl. 78, figs. $7-10$.

Types.-Thompson and Miller (1944, p. 495) noted that they designated the largest one of their sectioned-specimens as the holotype of the species, but they did not clearly indicate the specimen. The largest sectioned-specimen illustrated in their original paper was reproduced again as a syntype (Thompson, 1948, p. 48, pl. 9, fig. 1 ), so the holotype of this species is still uncertain to the readers. 
Material. -A number of sectioned-specimens obtained from the lowest part of the Kozaki formation are referable to this species, and some of them are illustrated here as examples for the sake of comparison.

Descriptive remarks. - This species was established on the Mexican specimens and was identified by KLING (1960) from Guatemala with remarks on the extent of variation and the geological range.

In the hexagonal shape of the shell with a cylindrical median area and conical lateral slopes the Kozaki specimens are quite similar to the types but are generally a little smaller in size than both of the types and the Guatemalan specimens. Their form ratios are equal to those of the types in the inner volutions but are smaller in the outer volutions. They also show a close resemblance to the types in the form and intensity of the septal fluting and in the statistical data such as the size of the proloculus, the septal counts, and the thickness of the spirotheca and the height of the volutions in the outer volutions. However, in detail the inner volutions of the Kozaki specimens are slightly larger in height and have a thicker spirotheca than the types (see Table 3 ).

Internally the most significant feature of this species is the fillings of a dense deposit along the axial area and in the regions adjacent to the tunnel. In this respect the Kozaki specimens are almost the same as the types, but the axial fillings of the Kozaki specimens are mostly confined to the inner four volutions.

KLING (1960) showed that the Guatemalan specimens of the species from the Chiantula section occur at the higher stratigraphic horizon than the types in the Chiapas section, and that they are associated with Eoverbeekina americana THOMPSON and Miller. The Guatemalan specimens are slightly larger than the types, to which the Kozaki specimens are closer in every respect.

The comparison of this species with similar American fusulines were already made by Thompson and Miller (1944) and Kling (1960). For the Japanese fusulines the comparable structure of the shell is seen in Parafusulina (Skinnerella) japonica (GüMBEL) and its subspecies. $P$. (S.) gruperaensis can be distinguished from them in having more distinct axial fillings and a shorter hexagonal shell.

This species is also similar to "Pseudofusulina" bactriana karasuensis Doutkevitch and KнAвAKov from Kara-su of East Pamir, but the latter has a shorter fusiform shell with a smaller form ratio and less dense axial fillings.

Occurrence.-Abundant in the lowest limestone member (b); loc. $\mathrm{Km} 7584$ and 7582, b in Eri-dani, and $\mathrm{Km} 1755$ (b member), and $\mathrm{Km} \mathrm{7566,} \mathrm{a} \mathrm{(d} \mathrm{member)} \mathrm{in} \mathrm{Kozaki-}$ dani. Associated species are listed in Table 8.

\section{Parafusulina (Skinnerella) figueroai (THOMPson and MilleR) Pl. 16, figs. $1-5$}

1944. Schwagerina figueroai Thompson and Mrber, Jour. Paleont., vol. 18, no. 6, p. 496-497, pl. 82 , figs. $1-4$.

\section{Compare. -}

1961. Schwagerina semilucera granda Nogami, Mem. Coll. Sci., Univ. Kyoto, Ser. B, vol. 27 , no. 3 , p. 191-192, pl. 5, figs. 6-8.

Types.-Thompson and Miller (1944) established this species on apparently more 
than three specimens. One of the axial sections of the syntypes should be designated by someone as the lectotype. It came from the La Vainilla Limestone of La Vainilla, Chiapas.

Material.-Fifteen specimens including six slightly diagonal and five sagittal sections are assigned to this species. Four of them are illustrated for the sake of comparison with the types and to show variation within the Kozaki specimens. The outer one or two volutions of these specimens have been exfoliated, and no complete specimens have been obtained.

Descriptive remarks. - Schwagerina figueroai is characterized by its thick fusiform shell with narrowly to sharply pointed poles and straight to slightly concave lateral slopes, rapid expansion of the shell, irregularly and strongly fluted septa, thick coating of a dense deposit on the septa in the central area adjacent to the tunnel, and its discontinuous axial filling in the inner volutions. In these features and the statistical data (see Table 4) the Kozaki specimens well agree with the types from Chiapas, but they show a fairly great variation in every detail.

As regards the shape of the shell some of the Kozaki specimens have distinct concave lateral slopes and highly extended and sharply pointed poles in the outer volutions just like in the Chiapas specimens, but some others have slightly convex lateral slopes, a less extended axis of coiling, and bluntly pointed poles (e. g. Pl.16, fig. 2). There are of course intermediate forms between both examples.

The variation in the extent of the axial fillings and of the dense deposits on the septa near the tunnel is well shown in the figures of Plate 16 . In figure 1 the deposits are confined to narrow areas along the axis of the inner volutions and near the tunnel, whereas in figure 2 they completely fill the chambers in the lateral and polar areas of the inner volutions and are not heavy near the tunnel region. There is gradation between the two types of fillings. The deposits of the former example are essentially the same as those of the Chiapas specimens.

The type and intensity of the septal fluting of the Kozaki specimens are essentially the same as those of the types. In the size of the shell, the form ratios of the corresponding volutions, the heights of the chambers and the proloculus size the Kozaki specimens are also nearly the same as the types. However, they have fewer septa and a thinner spirotheca for the corresponding volutions than the types.

As mentioned above the Kazaki specimens exhibit a fairly considerable variation in some respects, and those representing one extremity of the variation show a somewhat distinct difference from the types, but in the essential features they show a close resemblance. I would identify them with the species under consideration, although I hold a little hesitation to do that.

The comparison between $P$. (S.) figueroai and $P$. (S.) diversiformis (DunBar and Skinner) was already given by Thompson and Miller (1944, p. 497). Another similar species to $P$. (S.) figueroai is $P$. (S. ) semilucera granda described by NoGAMI (1961) from the Pseudofusulina krafti magna zone of the Atetsu Limestone of western Honshu, Japan. It has a much thicker fusiform shell and in general denser and wider axial fillings than $P$. (S. ) figueroai. Whereas the Kozaki specimens well agree with $P$. (S. ) granda in the heights of the chambers and the thickness of the spirotheca, and especially some specimens having a short fusiform shell with a dense axial deposit approach $P$. (S.) granda and are hardly distinguishable from it. The close similarity between these two forms suggests that they may belong to one and the same species to each other. 
Occurrence.-Abundant in a limestone lens at loc. 5004, g; associated with Schubertella giraudi (DePRAT) and Misellina claudiae (DEPRAT).

\section{Parafusulina (Skinnerella) nakamigawai MoRIKAwA and HoRIGUCHI}

\section{Pl. 18, figs. $1-4$}

1925. Schellwienia kaerimizensis Ozawa (pro parte), Jour. Coll. Sci., Imp. Univ. Tokyo, vol. 45 , art. 6 , p. 31 , pl. 4 , fig. 5 (not pl. 4, figs. 6,7 ; pl. 6 , fig. 5).

1956. Parafusulina nakamigawai Mortrawa and Hortauchi, Sci. Rep. Saitama Univ., Ser. B, vol. 2, no. 2, p. 262-263, pl. 35, figs. 1-7.

1958. Parafusulina nakamigawai; I Io and OaAa, Jubilee Pub. in the commemor. of Prof. H. Fujimoto, p. 52, pl. 2, fig. 5 .

1961. Parafusulina iwasensis Morikawa and Isomr, Report, Geol. Survey of Japan, No. 191, p. $24-25$, pl. 18 , figs. $1-6$ (not fig. 7 ).

Types. - This species was established by Morikawa and Horiguchi (1956) on several syntypes, of which the specimen illustrated as fig. 1 of pl. 35 is here designated as the lectotype.

Material. -A number of specimens are referable to this species. Some examples are illustrated to show the variation in the shape of the shell.

Description. - Shell large, subcylindrical to cylindrical with straight to gently curving axis of coiling and bluntly to broadly rounded polar ends. Central part of shell slightly depressed in most specimens.

Mature shells of $6-6 \frac{1}{2}$ volutions 14 to $15 \mathrm{~mm}$ long and 3.2 to $3.8 \mathrm{~mm}$ wide. Form ratio ranges from 3.7 to 4.2 . In inner 4 volutions poles sharply pointed and lateral slopes gently convex or straight. Shell rapidly increases in length in fourth volution to outer volutions.

Proloculus moderately large, spherical; its outside diameter measures 310 to 424 microns, averaging 384 microns for 12 well-centered specimens. Thickness of proloculus wall averages 43 microns in those specimens. Chambers increase in height uniformly throughout growth except in ultimate volution which is markedly lower in height than penultimate volution. Average heights of first to sixth volution of 11 specimens $123,171,249,304,396$, and 333 microns, respectively. Chambers slightly higher in polar regions than in central area in inner 3 volutions, but in outer volutions they greatly increase in height polewards from center of shell.

Spirotheca composed of a thin tectum and a keriotheca with fine alveoli. Its upper and lower surfaces covered with a thin layer of a dense material which is the same in nature as axial fillings. Its average thickness of first to sixth volution of 14 specimens $31,32,43,62,82$, and 85 microns, respectively.

Septa thin, although they are thickened by dense deposits in median portion of shell; closely spaced; narrowly and highly fluted throughout shell. Average septal counts of first to sixth volution of 10 specimens $14,27,31,36,39$, and 42 , respectively. Phrenothecae partly developed in fourth to sixth volution.

Tunnel narrow in inner volutions, but rather broad in outer ones. It is low, about one-third as high as chambers. Average tunnel angles of second to sixth volutions in 7 specimens $22,24,27,31,39$, and 40 degrees, respectively. Chomata present only in first volution. 
A dense deposit completely fills chambers of lateral regions of inner 2 or 3 volutions. In outer volutions these deposits never extend to polar regions, but thickens the septa in areas immediately adjacent to tunnel in most specimens.

Remarks. - In the cylindrical shell, thin spirotheca, thin and strongly fluted septa, and dense fillings in the inner two or three volutions and lining of the same deposits on the septa only in the narrow part near the tunnel, the specimens at my disposal are quite identical with the types from the Adoyama formation and also with the specimens described by IGo and OGawa (1958) from the Funafuseyama Limestone, although a minor difference is seen in that the Kozaki specimens have a smaller shell with fewer whorls. No information on the septal counts was given by the previous authors, but the number of the septa in the Kozaki specimens are shown in Table 5 .

As indicated by Morikawa and Horiguchi (1956, p. 263) and Toriyama (1958, p. 195), one of the syntypes of Parafusulina kaerimizensis Ozawa, which came from Tomuro, Tochigi Prefecture (Province of Kozuke), is not conspecific with the types of the species from the type locality, Kaerimizu of Akiyoshi, but is referable to $P$. (S.) nakamigawai, although, to our regret, the specimen is missing.

Parafusulina iwasensis MonIKAwa and Isom described from the lower part of the Ibukiyama Limestone at Iwasayama, east of Lake Biwa, central Japan, seems to be referable to $P$. (S.) nakamigawai, although the former has slightly less dense secondary deposits in the axial region.

The comparison of the present species with similar species such as Parafusulina (Parafusulina) setum Dunbar and Skinner, $P$. ( $P$.) nancei Thompson and Miller, and $P$. (Skinnerella) yabei HANZAw a has been made by the previous authors. Regarding the stratigraphic position of this species and the correlation of the Parafusulina zone between Japan and North America controversial opinions have been presented by Morikaw a and Horiguchi (1956) and Igo and OGAwA (1958), although both data on which their discussions were based were not so critical. The Kozaki specimens support IGo and OGAWA's opinion so far as the former problem is concerned, that is, they occur immediately below the Neoschwagerina simplex zone.

Occurrence. - Common in small limestone lenses at loc. $\mathrm{Km} \mathrm{5004,} \mathrm{b} \mathrm{in} \mathrm{Kozaki-}$ dani and loc. $\mathrm{Km} 5209$ at Uminoura, b member; see Table 8 for the associated species.

\section{Parafusulina (Skinnerella) cf. sapperi (StAFF) \\ Pl. 17, figs. 1, 2, 3(?), 4}

Compare. -

1912. Fusulina verneuili var. sapperi StafF, Palaeontographica, vol. 49, p. 181-183, pl. 19 , figs. $8,9,11,13(?)$.

1939. Parafusulina sapperi, Dunbar, Jour. Paleont., vol. 13, no. 3, p. 344-347, pl. 35 , figs. 1-6.

1936. Pseudofusulina kaerimizensis, Нuziмото, Sci. Rep. Tokyo Bunrika Daigaku, Sect. C, no. 2, p. 65-67, pl. 7, figs. 6-8; pl. 8, figs. 1-4.

1957. Parafusulina kaerimizensis, Koвayashi, Sci. Rep. Tokyo Kyoiku Daigaku, Sect. C, no. 48 , p. 291-292, pl. 7 , fig. 1 .

1957. Parafusulina sapperi, Kоватаsнi, Ibid., p. 292-293, pl. 6, figs. 6,7 .

Types. - This species was first described as Fusulina verneuili var. sapperi from Guatemala on four syntypes and was later separated by DunBAR (1939) as a distinct species with one (pl. 19, fig. 11) of STAFF's syntypes as the lectotype [Dunbar, 1939, 
p. 345 , pl. 35, fig. 1 (reproduced figure of STAFF's fig. 11)].

Material. - The specimens, of which only a few are well oriented, are probably referable to this species, but the identification is tentative because of insufficiency of the material.

Descriptive remarks. - Shell thickly fusiform with flat or gently convex equatorial area and slightly convex lateral slopes. Poles narrowly rounded in adult shells but sharply pointed in immature stages. Since the outer one or two whorls of the examined specimens have been exfoliated, the true size of the mature shell can not be obtained. Shells of $6-7$ volutions attain 12.5 to $13.5 \mathrm{~mm}$ in length and 3.6 to 4.0 $\mathrm{mm}$ in width, giving form ratios of 3.3 to 3.7 .

Proloculus ranges from 372 to 475 microns in its outside diameter. Shell expands rapidly; heights of first to sixth volution of one (Pl.17, fig. 1) of the figured specimens 152, 202, 226, 282, 370, and 386 microns, respectively. Those of first to seventh volution of another figured specimen (P1.17, fig. 3), which is uncertainly conspecific with the specimen mentioned above, increase rather slowly and measure $102,130,164,205,328,287$, and 328 microns, respectively. In the former specimen thickness of spirotheca of first to sixth volution is 40 (?), 60, 64, 72, 112, and 112 microns, respectively, and that of the latter specimen is thinner than that of the former for the corresponding volutions, measuring $32,36,64,72$, and 90 microns, respectively.

Septa strongly and narrowly fluted. Fluting regular in central area, but becomes rather irregular towards polar areas in outer volutions. Cuniculi well developed. Septal counts of second to sixth volution in one specimen $22,27,34,39$, and 45 , respectively.

Rudimentary chomata occur only in the inner $1 \frac{1}{2}$ volutions. In many of the specimens a dense deposit fills the axial zone of the inner volutions, but as in the Guatemalan specimens, the deposit is unequally developed in different specimens. A less conspicuous axial filling is, for example, represented in the specimen illustrated as fig. 2 of Pl. 17. Phrenotecae are developed in some specimens.

The specimen shown as fig. 1 of Pl. 17 is hardly distinguishable in every respect from the lectotype of the species under consideration, and another example of fig. 2 of the same plate, which has a less conspicuous axial filling, is also indiscriminated from one of the syntypes (STAFF's pl. 19, fig. 13) which was considered by Dunbar (1939, p. 344, 345, pl. 35, fig. 2; reproduced from STAFF's fig. 13) as uncertainly conspecific with the lectotype. Both of the Kozaki specimens were obtained from one and the same rock specimen, and seem to represent mere variants to each other within the species. Further interesting materials are such other specimens as shown in figs. 3 and 4 , which are partly silicified just like in the specimens illustrated by Dunbar (pl. 34, figs. 3, 4, and 5).

Parafusulina sapperi was identified by KоваYAshi (1957, p. 292, pl. 6, figs. 6 , 7) from the Ibukiyama Limestone of Shiga Prefecture. I am of the opinion that the Kobayashi's $P$. kaerimizensis (p. 291, pl. 7, fig. 1 ) is also referable to $P$. (S. ) sapperi. ToRIYAMA (1958, p. 197) and NogAmi (1961, p. 208) separated P. kaerimizensis described by Fujimoto (Huzimoto, 1936, p. 65, pl. 7, figs. 6-8; pl. 8, figs. 1-4) as a different species. It may probably be referable to the species under consideration.

Occurrence. - From the e member at loc. Km 5007, a in Kozaki-dani. Uncertainly referred specimens are from loc. $\mathrm{Km} \mathrm{7574,} \mathrm{b} \mathrm{in} \mathrm{Mameguri-dani} \mathrm{and} \mathrm{Km} \mathrm{5107,} 300 \mathrm{~m}$ west of Oshino. See Table 8 for the associated species. 
Subgenus Parafusulina (Parafusulina) Coogan, 1960

Type-species. - Parafusulina wordensis Dunbar and Skinner

Subgeneric diagnosis and remarks. - See pages 94-95

Parafusulina (Parafusulina) kaerimizensis (OzAwA)

P1. 16, figs. 6 , 7; pl.17, figs. $5-7$; pl. 18, figs. 5-8

1925. Schellwienia kaerimizensis OzaWA, Jour. Coll. Sci., Imp. Univ. Tokyo, vol. 45, Art. 6, p. 31-32, pl. 4, figs. 6, 7; pl. 6, fig. 5 (not pl. 4, fig. 5).

? 1959. Parafusulina kaerimizensis, KanUma, Bull. Tokyo Gakugei Univ., vol. 10, p. 81, pl. 9, figs. 1-3.

1958. Parafusulina kaerimizensis, Toriyama, Mem. Fac. Scj., Kyushu Univ., Ser. D, vol. 7, p. 194-197, pl. 30, figs. 6-12; pl. 31, figs. 1-8; pl. 32, figs. 1-9.

1961. Parafusulina kaerimizensis, Nogami, Mem. Coll. Sci., Univ. Kyoto, Ser. B, vol. 27 , no. 3, p. 206, pl. 8, figs. $1-5$.

1959. Parafusulina kaerimizensis, Toriyama and Sugr, Mem. Fac. Sci., Kyushu Univ., Ser. D, vol. 9, no. 1, p. 22, pl. 2, figs. 1-3.

? 1962. Parafusulina kaerimizensis, Sty vol. 12 , p. 28 , pl. 9 , fig. 5 .

Lectotype.-Ozawa's specimen No. 11-81, figured as fig. 7 of pl. 4 (=fig. 5 , of pl. 6), designated by Toriyama (1958, p. 165); from the Kaerimizu doliné, Akiyoshi Limestone.

Material. -A number of specimens are identified with this species, some of which are figured to illustrate the range of the shape in this somewhat variable species.

Descriptive remarks. - This well known species has been fully described and illustrated by ToRIYAMA (1958) on OzAWA's original material and many topotypes. The diagnostic features of the species shown in the lectotype and the syntype are the elongate subcylindrical to cylindrical shell, close and uniform coiling in the inner volutions, and narrow but dense axial fillings in inner several volutions. On examining a number of topotypes, however, Toriyama indicated that the species shows a considerable variation in the features mentioned above and that the lectotype represents one extremity within the variation of the species, showing the slowest expansion of the shell and having a thinner spirotheca. Most of the topotypes illustrated by him have much broader axial fillings which extend even to the outer volutions.

Good examples identified with this species are the specimens from the Atetsu Limestone of Okayama Prefecture (NogAmi, 1961), which represent a greater expansion of the shell in the inner volutions than in those of the lectotype.

The Kozaki specimens herein referred to this species are closer to ToriYama's and Nogam's specimens than to the lectotype in every respect, but on comparing them directly with the lectotype and TORIYAMA's topotypes still minor differences can be seen in having a thicker spirotheca in the inner corresponding volutions and a little greater expansion of the shell than the lectotype in the inner volutions. However the obtained statistical data for those volutions fall within the variation shown by ToriYama's and Nogami's specimens. For the sake of comparison some examples of the measurements of the Kozaki specimens are shown in Table 6 . I agree with TORIYAMA and NogAmI in separating the specimens referred to this species by FuJIмото (Huzimoto, 1936) and Morikawa (1955) from the Kwanto massif, and those 
by Kobayashi (1958) from the Ibukiyama Limestone of Shiga Prefecture.

The specimens identified by MorIKawa with this species from the Shimokuzu conglomerate in the Kwanto massif are also distinctly different from this species in having thicker spirotheca for the corresponding volutions, more weakly fluted septa, and less extensive axial fillings in the inner volutions.

Occurence. - Abundant in the limestone of the e and f members; locs. 5007, a, b; 1696; 7574. Associated species are listed in Table 8.

\section{Parafusulina (Parafusulina?) sp.}

P1. 14, figs. 19-21

Material. -The specimens which are described under the above heading include seven axial sections. No sagittal section has been obtained.

Description. - Shell small to moderate, cylindrical, with a straight to slightly curving axis of coiling and broadly rounded or truncated poles. Specimens of $6^{\frac{1}{2}}$ volutions measure 6.5 to $8.0 \mathrm{~mm}$ in length and 1.8 to $2.2 \mathrm{~mm}$ in width, and the largest one of 7 volutions about $8.9 \mathrm{~mm}$ long and $2.7 \mathrm{~mm}$ wide. Form ratio ranges from 3.2 to 3.4 in mature shells.

Proloculus usually ellipsoidal and occasionally spherical; outside diameter in its longer axis ranges from 184 to 390 microns. Shell expands slowly and uniformly throughout growth. Heights of first to sixth volutions of 5 specimens average 87, $127,145,158,175$, and 209 microns, respectively. Heights of chambers gradually increase polewards from central part of shell.

Spirotheca thin, finely alveolar. Thickness of spirotheca in first to fifth volutions in typical 4 specimens ranges between 20 and 30,28 and 37,35 and 40,37 and 40 , and 41 and 49 microns, respectively.

Septa thin, intensely and narrowly fluted throughout length of shell. Fluting rather regular and forms chamberlets that reach about a half to two-thirds the heights of chambers. Cuniculi present in outer volutions. Septal counts can not be given because of no well-oriented sagittal section.

Tunnel irregular in its path and width. Chomata recognizable only in first volution; very narrow. Dense deposits fill chambers in a wide belt along axial region of all volutions except of first and outermost ones. Septa more or less coated with the same deposit even in central part of shell.

Remarks. - The characteristics of the present specimens are the long cylindrical shell with slowly and uniformly coiled volutions, the wide and heavy axial fillings, and the strong and regular fluting of the septa. In these respects the specimens are very close to Parafusulina? gregaria from the basal part of the Swine Limestone of South China (LEE, 1931; CHEN, 1934), but further material of sagittal section is needed for the precise identification.

The present specimens are seemingly immature examples of Monodiexodina $k u$ mensis sp. nov., which is described in the following pages. However, they have a higher and more irregular septal fluting and larger heights of chamber and a shorter elongation of the shell for the corresponding volutions.

Occurrence. - Rarely found in limestone lenses of the b member at loc. $\mathrm{Km} \mathrm{5004, \textrm {g }}$ in Kozaki-dani and loc. $\mathrm{Km} 5209$ in Uminoura. 


\section{Genus Monodiexodina Sosnina, 1956}

Type-species. -Schwagerina wanneri sutschania DouTKeviTch, 1935

Diagnosis. -Shell large, highly elongate cylindrical, with rounded poles, a straight to broadly curving axis of coiling and flat or slightly undulating lateral sides. Proloculus relatively large. Shell expands slowly and uniformly. Septa narrowly and regularly fluted throughout length of shell, and the fluting is mostly limited to the lower part of the septa. Low cuniculi may be developed. Tunnel singular. Dense deposit fills axial and polar areas. Chomata absent in most volutions except in inner one or two volutions in which rudimentary chomata may occur.

Remarks. - The distinction between this genus and other related genera such as Parafusulina, Pseudofusulina is concisely indicated by Coogan (1960). He ranked this genus as a subgenus of Farafusulina. As I (1958, p. 171) pointed out, however, several species which are considered as ancestral forms of this genus are found in the Upper Carboniferous and Lowest Permian schwagerinines of the Triticites-stage. They are, for example, Triticites langsonensis SAURIN, T. samaricus RAUSER-CERNoussova, T. uddeni Dunbar and Skinner (1936, pl. 47, figs. 1-7, 11; not figs. 8, 9), T. ferganensis M. -Maclay. With the last species M. -Maclay (1959) established the genus Ferganites, to which he assigned $T$. neglectus NewelL, $T$. secalicus oryziformis NewELL, T. secalicus SAY, etc. These species have an elongate subcylindrical and uniformly expanded shell of a moderate size and low and evenly fluted septa near the poles.

The representatives of this phylogenetic stock in the middle and upper Pseudoschwagerina zone are Schwagerina prolongata(BERRY), S. linearis DUNBAR and SKINNER, and $S$. steinmanni DUNBAR and NEwELL, which can be regarded as the early members of Monodiexodina. Coogan (1960) proposed Eoparafusulina as a subgenus of Parafusulina with P. gracilis (MEeK) (Thompson and WHEeler, 1946, p. 31-32, pl. 1, figs. 6-10) as the type-species. I would place it as a subgenus of Monodiexodina, though $P$. gracilis has a slightly different shell structure in the inner volutions. Parafusulina alaskensis Dunbar which can be safely referable to Monodiexodina is intermediate in structure between the typical Monodiexodina and Eoparafusulina.

Thus the species of the Ferganites-Monodiexodina series are considered to have constituted a distinct phylogenetic stock which can be separated from other stocks or groups of the Schwagerininae.

The only one species of Monodiexodina has been described from Japan. It is $M$. matsubaishi (Fujimoto) from the Middle Permian Kanokura formation of the Kitakami massif. It has also been found in a pebble of the Takagami conglomerate at the Choshi Head, east of Tokyo (MAeda and Mitsuoka, 1961).

Monodiexodina kumensis, sp. nov.

Pl. 19, figs. 1-7

Material. -Holotype, GKD 12447 (Pl. 19, fig. 1); Paratypes GKD 12454 (Pl. 19, fig. 2), 12448 (Pl. 19, fig. 3), 12459 (Pl. 19, fig. 4), 12453 (Pl. 19, fig. 5), 12456 (Pl. 19, fig. 6), 12449 (Pl. 19, fig. 7): All the specimens obtained are incomplete and their outer few volutions have been exfoliated. 
Description. - Shell large, highly elongate, cylindrical, with flat or undulating low slopes, a slightly and broadly curving axis of coiling. Poles rounded in outer volutions, but bluntly pointed in inner two volutions. Due to incompleteness of the specimens the true size and numbers of volution of the mature shells can not be known, but the mature shells attain at least $16 \mathrm{~mm}$ long and $2.2 \mathrm{~mm}$ wide, giving form ratios ranging from 7.0 to 8.5 .

Shell expands uniformly but extends rapidly in length throughout growth of shell. Proloculus spherical or somewhat irregular; its outside diameter attains 270 to 370 microns. Heights of first to sixth volutions of the holotype 96, 100, 112, 128, 160, and 194 microns, respectively. Those of the same volutions of three paratypes 84-96, $96,100-112,112-115,168$, and 184-210 microns, respectively. Chambers slightly higher in polar regions than in central areas.

Spirotheca relatively thin, composed of a thin tectum and a very finely alveolar keriotheca. Thicknesses of spirotheca of first to seventh volution of the holotype 24, $29,32,32,40,44$, and 48 microns, respectively. Those of first to sixth volution of two paratypes $21-24,24-27,30-32,30-32,30-40$, and 37-39 microns, respectively.

Septa rather thick, composed of a downward deflection of the tectum, a wedgelike pycnotheca and a keriotheca. Septal counts obtained in incomplete specimens 8 , $16($ ?) $, 19,21,23$, and 29 for first to sixth volution, respectively. Septal fluting regular and confined to lower half of septa in the central two-thirds the length of shell and becomes higher and irregular towards polar areas. Intercepts of septal flutes in the axial section are even and semicircular in shape. Cuniculi developed at the end of the septa in outer volutions.

Tunnel as high as one-half height of chamber; narrow in inner volutions and become rapidly wider in outer volutions. Tunnel angles of first to sixth volution of the holotype $20,26-32,27-35,29-34,30-40$, and 42 degrees, respectively. Those of first to fifth volution of a paratype (Pl.19, fig. 2) 21, 31, 35, 37, and 52 degrees, respectively. Rudimentary chomata present only in first volution.

A dense deposit fills chambers along the axis almost across entire length of shell and also thickens septa in polar areas.

Remarks. - The obtained specimens have been ill-preserved, but they are better referable to Monodiexodina than to any other genera in its elongate cyclindrical and uniformly expanding shell, low and even septal fluting and heavy axial filling. This species most closely resembles $M$. matsubaishi (Fujimoto) from the so-called Parafusulina zone in the Kitakami massif (Fujimoto, 1956) and from a pebble of the Takagami conglomerate of the Choshi Head (MAEdA and MitsuokA, 1961). M. matsubaishi, however, has a more regular and lower septal fluting, more narrowly rounded poles, and a smaller proloculus than those of this new species. This species can be easily distinguishable from the previously known other species of Monodiexodina.

Occurrence. - Common in a limestone lens at loc. $\mathrm{Km} \mathrm{5004,} \mathrm{b} \mathrm{of} \mathrm{the} \mathrm{b} \mathrm{member}$ in Kozaki-dani. Associated species are listed in Table 8.

Family Verbeekinidae STAFF and WedekIND, 1910

Subfamily Verbeekininae STAFF and WEDEKIND, 1910

Genus Verbeekina STAFF, 1909

Type-species. -Fusulina verbeeki GeInITz, 1876 
Synonymy.-Paraverbeekina MikLukHo-MACLAY, 1955

Diagnosis.-See Thompson, 1948, p. 57-58

Remarks. -Miklukho-Maclay (1955) set up the genus Paraverbeekina for elongate verbeekines with Paraverbeekina pontica M.-MACLAY as the type-species, and he confined the genus Verbeekina only to spherical verbeekines. His subdivision of the Verbeekininae may be convenient to some extent for distinction of elongate forms from spherical ones, but between the two types there is no essential difference in the structures, but is complete gradation of intermediate forms that one feels difficulty to which one of them better assigned. He stated that "Paraverbeekina has the loose coiling in the late chambers". However the holotype of the type-species is undoubtedly not a full-grown complete shell, but its outermost one or two volutions must have probably been exfoliated or not grown. Moreover the two genera under consideration can not be distinguished in their stratigraphical occurence since they have been known to occur nearly in parallel. I would refer Paraverbeekina as a subgenus of Verbeekina only from the stand-point of convenience for the morphological distinction, until the phylogenetical relation among verbeekines is well understood.

M. - Maclay (1955) also established the genus Armenina in the Neoschwagerinidae with $A$. karinae M.-MAclay as the type-species. According to him it has a few spiral septula in the outermost volution. So far as the original figure (1955, fig. e; 1957, pl. 4, figs. 1) of the type-species is concerned, however, no spiral septula can be seen, and the species is probably referable to Verbeekina. The incomplete sagittal section (1957, pl. 4, fig. 2) assigned to $A$. karinae appears to have a few axial septula in the outer volutions, but I doubt if the specimen is really conspecific with the holotype of the species. The figure looks like a sagittal section of a Misellina. In the same papers $(1955,1957)$ he described $A$. salgirica M. -MaClay, which seems to be referable to Misellina rather than Armenina.

Armenina may be distinguished from Verbeekina, if it really has spiral septula, but in other respects of the shell structures it has no distinct difference from the latter. I expect that the genus should be described more precisely with adequate illustrations.

\section{Verbeekina sphaera OzAwA}

Pl. 15, figs. 1-6

1927. Verbeekina verbeeki sphaera Ozaws (pro parte), Jour. Coll. Imp. Univ. Tokyo, vol. 45, art, 4, p. 153, pl. 38, figs. 14, 16-a (not fig. 15); pl. 35, fig. $10 \mathrm{~b}$.

? 1956. Verbeekina verbeeki sphaera, CHEN, Palaeontologia Sinica, n. s. B, no. 6, p. 48, pl. 9, figs. 11, 12 .

1960. Verbeekina sphaera, Sugr, Trans. Proc. Paleontol. Soc. Japan, n. s. no. 39, p. 312-319, pl. 36 , figs. $1-20$.

Lectotype. - The specimen of fig. 16 (axial section) of OzAwA's pl. 38 (1927) (Sl Samé, Akasaka-6) designated by Sugi (1960, p. 313).

Material.-More than seventeen sectioned-specimens were examined, five of which are illustrated in this paper. The lectotype and syntypes, and the hypotypes described by Sugr were also examined for the sake of comparison.

Description on the lectotype. - Sugr (1960) designated one of Ozawa's syntypes as the lectotype of this species and gave a detailed description on his hypotypes of the 
species from the Cancellina nipponica zone ( $\mathrm{Nn}$ ) of the Akasaka Limestone, but he did not give a description of the lectotype itself. In this occasion of referring the Kozaki specimens to the species I have examined OzAWA's original specimens.

The lectotype (OzawA's fig. 16 of pl. 38) is represented by a tangential section of probably a mature, but not full-grown, specimen, which was sectioned through the outer periphery probably of the first volution nearly in parallel to the axis of coiling of the shell. The specimen has at least nine volutions, and is $3.15 \mathrm{~mm}$ long and $2.87 \mathrm{~mm}$ wide, giving a form ratio of 1.1 . The inner, probably two, volutions, have a short axis of coiling which is at large angles to that of the outer volutions. The form ratios of the second to the fifth volution are, although not strictly exact because of the incompleteness of the section, .97, .99, 1.0, and 1.06 , respectively. The heights of the volutions of the second to the ninth volution are $48,70,108,160$, $210,220,210$, and 242 microns, respectively. Thus the shell expands uniformly.

The spirotheca is composed of a tectum, a keriotheca with very fine alveoli, and a very thin inner dark layer, the tectorium. The thickness of the spirotheca of the second to the fifth volution is $12,19,29$, and 32 microns, respectively, and that of the seventh to the ninth volution is 40,45 , and 36 microns respectively.

The parachomata are very prominent, high and broad, and seem to be continuous across the chambers throughout the growth. They are counted 16 in the penultimate whorl, and 21 or 20 in the ultimate whorl.

The septa seen in the parallel section of OzawA's original specimen (pl. 38, fig. 16) are nearly normal to the whorl.

Descriptive remarks on the Kozaki specimens. $-V$. sphaera is characterized by a small shell, relatively thick spirotheca for the genus, a uniform expansion of the shell, and large and massive parachomata developed mostly across the chambers. In these respects and the statistical data the Kozaki specimens are almost identical with the lectotype, but a little difference is seen in that the parachomata of the Kozaki specimens are in general less prominently developed and are discontinuous in the central part of the chambers of the inner volutions. However they are as large and massive as those of the types at the junction with and near the septa, and the difference mentioned above is regarded as a variation within the species.

The largest specimen obtained has more than 13 volutions and measures $4.2 \mathrm{~mm}$ wide and $5.2 \mathrm{~mm}$ long, being much larger than the lectotype which is not a fullgrown shell of probably 10 volutions. The form ratios of two well-oriented axial sections ( $\mathrm{Pl} .15$, figs. 2 and 1 ) are 1.0 and 1.1 , respectively. The other statistical data of the Kozaki specimens are shown in Table 7 .

Regarding the structure of the spirotheca and septa, and the coarseness of alveoli of the spirotheca there is no difference between the types and the Kozaki specimens.

CHeN (1956) identified this species on the specimens from the Maok'ou Limestone of the Kwangsi province. His specimens have poorly developed parachomata, as he stated. He noted that "they (parachomata) appear in the early and last whorls but disappear in the middle ones". We can understand this respect such that the parachomata are discontinuous in the central part of the chambers. If the sectioned plane is crossed near or at the junction with the septa, the parachomata are to be seen by all means.

Occurrence. - This species occurs not uncommonly in the upper part of the lower subformation, and is most abundant in the e and $\mathrm{f}$ members. The collecting localities and the associated species are shown in Table 8. 


\section{Verbeekina sp.}

PI. 15, figs. 7,8

Material. - Only two incomplete specimens, each of which came from different localities, are before me.

Descriptive remarks. - The shells of two specimens are small for the genus, and show a slight difference from each other in the shape, the mode of coiling, and the thickness of the spirotheca in the inner volutions, but owing to insufficiency of the material it is uncertain whether they represent variation within one and the same species or different species from each other. I here tentatively treat them as being the same species.

One of the specimens (Pl. 15, fig. 7) is approximately $1.88 \mathrm{~mm}$ long and 1.76 $\mathrm{mm}$ wide in 11 volutions, having a slight short axis of coiling and small umbilicate poles. Shell expands uniformly; heights of volutions in third (probably $2 \frac{1}{2}$ th) to eleventh $\left(10 \frac{1}{2}\right.$ th) volution $64,80,120,160,210,250,226,274$, and 242 microns, respectively. Spirotheca typical for the genus and very finely alveolar; its thickness $16,18,25,25,25,29,31$, and 34 microns, respectively, for second to tenth volution.

The other specimen (Pl.15, fig. 8), although it is not sectioned accurately along its axis, measures about $1.80 \mathrm{~mm}$ in length and $1.76 \mathrm{~mm}$ in width, giving an approximate form ratio of 1.1. Shell tightly coiled in inner 5 volutions; heights of second to eleventh volution $48,64,96,110,176,194,210,226,258$, and 226 microns, respectively. Spirotheca relatively thick in third to sixth volution but becomes thinner in outer volutions. It measures $12,16(?), 36(?), 41,41,30,28,32,28$, and 28 microns, respectively, for second to eleventh volution.

In the two specimens the chomata are very small and occur only immediately adjacent to the septa.

These specimens differ distinctly from the types of Verbeekina sphaera in their shorter axis of coiling, thinner spirotheca, and smaller chomata, but one of them (GKD 12116) somewhat approaches a spherical form of $V$. sphaera (Pl. 15, fig. 3), and the other (GKD 12085) is somewhat similar to V. grabaui THOMPson and FosTeR from Mt. Omei, China. For accurate determination more complete specimens are needed.

Occurrence. - One specimen (GKD 12116) came from loc. Km 7574, b, and the other (GKD 12085) from loc. $\mathrm{Km} \mathrm{7566,c,} \mathrm{both} \mathrm{in} \mathrm{Kozaki-dani.}$

Genus Pseudodoliolina YABE and Hanzawa, 1932

Type-species. -Pseudodoliolina ozawai YABE and HANZAWA, 1932 (=Doliolina lepida Deprat, 1914, pl. 3, figs. 12-14)

Remarks. -The genus Pseudodoliolina was originally distinguished from the genus Doliolina (=Misellina) by lacking a keriotheca in its spirotheca, which consists of a single dense layer. Later studies, however, clarified that a less dense layer with fine lines normal to its surface is discernible below the tectum in the outer volutions of the topotypes of the type-species (Thompson and Foster, 1937; THOMpson, 1948) and of the specimens of the same species of Akiyoshi (Toriyama, 1958). I examined many topotype specimens of the type-species and recongnized the same structure of the spirotheca in the outer volutions, although the lower layer was not discernible 
distinctly from the tectum unless the specimen was sectioned enough thin. The identical structure of the spirotheca has been recognized in Pseudodoliolina pseudolepida pseudolepida (Thompson and Foster, 1937), P. oliviformis (Thompson, Wheeler and DANner, 1950), and P. pseudolepida gravitesta (KANMERA, 1954). The last subspecies from the Lepidolina zone of the Kuma massif has a spirotheca which consists essentially of a tectum and a somewhat transparent layer with very fine alveoli throughout the shell and is coated with a dense deposit on the upper and lower surfaces.

Recently IsHir and Nogami (1961) established the genus Metadoliolina with Pseudodoliolina pseudolepida gravitesta as the type-species. They laid considerable stress on that the genus has a well-differentiated lower layer of the spirotheca. However the same structure of the spirotheca has already been recognized even in the typespecies of Pseudodoliolina as mentioned above, although the alveoli of the lower layer are not so distinct as in gravitesta. Anyhow between the two genera there is no such essential difference in the spirotheca and other structures as to separate them from each other, although it may be convenient to rank Metadoliolina as a subgenus of Pseudodoliolina for advanced forms of this group with a large shell and a thick spirotheca. In the species-group of $P$. pseudolepida the lower layer of the spirotheca is much clearer than that of $P$. ozawai. A species described below is probably predecessor of the $P$. pseudolepida, and the two species exhibit the identical spirothecal structure in the outer volutions.

\section{Pseudodoliolina aff. pseudolepida pseudolepida (Deprat)}

P1. 14, figs. $15-18$

Compare. -

1912. Doliolina pseudolepida Diprat, Mem. Serv. Geol. 1'Indochina, vol. 1, fasc. 3, p. 46 , pl. 5 , figs. $6-9$, pl. 6 , fig. 4 .

1912. Doliolina lepida Daprat, Ibid., p. 45-46, pl. 5, fig. 10; pl. 6, figs. 1-3.

1913. Doliolina lepida mut. pseudolepida, Deprat, Ibid., vol. 2, fasc. 1, p. 50.

? 1925. Doliolina lepida, LANGE, Geol.-mijnb. genootsch. Nederland en Kolonien Verh., Geol. Ser., deel 7, p. 262.

? 1927. Doliolina lepida, Ozawa, Jour. Fac. Sci., Imp. Univ. Tokyo, sect. II, vol. 2, pt. 3, p. 152-153, pl. 45, fig. 1.

1935. Doliolina lepida, Gubler (pro parte), Mem. soc. geol. France, n.s., tome 2, fasc. 4 , p. 95-99, pl. 4, figs. 3-5, 6(?), 7; pl. 5, figs. 14 , 15 (not pl. 4, figs. 8-12).

1937. Pseudodoliolina pseudolepida, Tномpson and Foster, Jour. Paleont. vol. 11, p. 141142, pl. 25, figs. $2-4$.

1948. Pseudodoliolina pseudolepida Тномгео, Univ. Kansas, Paleont. Contr. Protozoa, Art. 1, pl. 17, figs. 3,4 .

1955. Pseudodoliolina pseudolepida, Kochansky-Devidé, Slovenska Akademija znanosti in Umetonosti, Class IV, 3, p. 416, pl. 4, figs. 7-10; pl. 8, fig. 6.

? 1957. Pseudodoliolina ozawai, КовауаянI, Sci. Rep. Tokyo, Kyoiku Daigaku, Sect. C, no. 48 , p. $298-300$, pl. 8 , figs. 1,2 ; pl. 9 , figs. $1-4$.

1958. Pseudodoliolina pseudolepida, Torixama, Mem. Fac. Sci., Kyushu Univ., Ser. D, vol. 7, p. 211-212, pl. 39, figs. 20-25.

1961. Pseudodoliolina pseudolepida, Nogami, Mem. Coll. Sci., Univ. Kyoto, Ser. B, vol. 28 , no. 2 , p. $163-164$, pl. 1 , figs. $7-11$.

Lectotype of Pseudodoliolina pseudolepida pseudolepida.-DePrat's original specimen illustrated as fig. 6 of pl. 5 in 1912; designated by ToriYama (1958, p. 211).

Material. -Specimens including two axial sections, one tangential section, and 
several random oblique sections, have been obtained. Probably a few outer volutions of axial sections [GKD 12308, a (Pl.14, fig. 15); GKD 12113, (Pl.14, fig. 16)] have been exfoliated, and a specimen of an oblique section has at least fifteen volutions.

Description.--Shell subcylindrical with broadly rounded poles. A typical specimen of 12 volutions attains $4.34 \mathrm{~mm}$ in length and $2.05 \mathrm{~mm}$ in diameter, and gives a form ratio of 2.1. Its proloculus is $0.14 \mathrm{~mm}$ in outside diameter.

Shell tightly coiled; heights of first to twelfth volution in the specimen mentioned above $32,40,48,50,56,76,80,91,104,120,128$, and 136 microns, respectively. Form ratio in the same specimen $1.5-1.75$ in the juvenarium, attaining the largest in sixth to eighth volution where it is 2.3 , and gradually declines to 2.1 in outer volutions.

Spirotheca composed essentially of a very thin dense layer - the tectum - and a less dense lower layer (see Pl.14, fig. 18). In the outer volutions the lower layer shows a distinctly alveolar structure - the keriotheca. The upper surface of the tectum and the lower surface of the keriotheca are discontinuously lined with a very thin dark desposit which is the same in texture as the parachomata. In the inner two volutions this structure of the spirotheca can be discriminated in some parts. The thickness of the three layers excluding the uppermost deposit of the spirotheca in the typical specimen mentioned above is $8,9,10,12,14,16,20,22$, and $27 \mathrm{mi}-$ crons, respectively, for the third to the eleventh volution. Nearly the same measurements are given also in other specimens.

Parachomata well developed throughout shell; rounded at their top in the midst of chambers and become higher and narrower near and adjacent to septa. Foraminae small; circular in cross-section.

Remarks. - The species described above are much closer to Pseudodoliolina pseudolepida pseudolepida DePrat than to any other known species of the genus in the general shape of the shell, the attitude of the parachomata, and in the structure of the spirotheca. However they have a smaller shell with fewer volutions, smaller heights for the corresponding volutions, a smaller proloculus, and fewer foraminae and parachomata for the corresponding volutions. Thus they are smaller in every respect than the original types and the hypotypes of $P$. pseudolepida pseudolepida described by Thompson and Foster (1937) and ToRIYAMA (1958), but their structures show a close similarity to each other in every respect. The previously described specimens of the species are all from the younger horizons than the present specimens, namely Deprat's types are associated with Sumatrina annae, Thompson and FosTeR's hypotypes occur together with $N$. aff. craticulifera and Verbeekina grabaui, and Torryama's came from the $N$. craticulifera zone. These facts suggest that the Kozaki specimens can be regarded as a predecessor of P. pseudolepida pseudolepida, but owing to the insufficiency of material, I hesitate to erect a subspecies for them.

The specimens under consideration are somewhat similar to $P$. chinghaiensis SHENG from the Maok'ou Limestone of Chinghai, but they have a more distinct lower layer of spirotheca and a broader parachomata.

Occurrence. - Rarely occurs in the limestones of the $\mathrm{f}$ member at loc. $\mathrm{Km} 7574$ in Mameguri-dani, Associated species are listed in Table 8. 
Subfamily Neoschwagerininae DunBar and CondRA, 1928 Genus Misellina Schenck and Thompson, 1940

Type-species. - Misellina ovalis Deprat, 1915

Remarks. - The generic diagnosis and historical review of the genus and comparison of it with other related genera were given in detail by SchencK and THOMPson (1940) and Thompson (1948). Many authors mentioned that the genus and Pseudodoliolina constitutes one branch in the subfamily Verbeekininae. However I am of the opinion that Misellina is ancestral to the Neoschwagerininae and Sumatrininae (KANMERA, 1957). I would also regard Brevaxina as an aberrant form of Misellina. The typespecies of Misellina and Brevaxina have a thick spirotheca and septa both with coarse alveoli. Whereas Verbeekina and Pseudodoliolina have a thin spirotheca and septa both with very fine alveoli. Although the latter two might also have been derived from early members of Misellina, most of Misellina hitherto known have much closer features to Neoschwagerina and Cancellina than to Verbeekina and Pseudodoliolina.

The earliest representative of Misellina known in Japan is M. ibukiensis Kobayashi which was originally described from the middle part of the Pseudofusulina ambigua zone of the Ibukiyama Limestone of central Japan (KовAYASHI, 1957). Recently MoRIKAwA and Isomi (1961) reported that it occurs associated with Paraschwagerina (Acervoschwagerina) endoi and Paraschwagerina gigantea from the Samegai formation in the east of Lake Biwa. It has a very small shell with a thin spirotheca and septa and might be ancestral to both Verbeekininae and Neoschwagerininae. A species of Misellina similar to $M$. ibukiensis is $M$. aff. claudiae obtained from a limestone pebble in a conglomerate of the Kozaki formation (KANMERA, 1956, pl. 36, fig. 15). It is associated with Pseudofusulina parumvoluta (DEPRAT), P. vulgaris(Schellwien), $P$. sp., Nagatoella aff. kobayashii Thompson, and Toriyamaia laxiseptata KanmerA.

\section{Misellina claudiae (DEPRAT)}

P1. 14, figs. 7-14

1912. Doliolina claudiae Deprat, Mem. Serv. Geol. l'Indochine, tome 1, fasc. 3, p. 4445 , pl. 4 , figs. $5-9$.

1913. Doliolina claudiae, Deprat, Ibid., tome 2, fasc. 1, p. 50.

1925. Doliolina claudiae, Ozawa, Jour. Coll. Sci., Imp. Univ. Tokyo, vol. 45, no. 4, p. 18, pl. 2, figs. 1,2 .

1925. Doliolina claudiae, Ozawa, Ibid., vol. 45 , no. 6 , p. 52-53, pl. 11, figs. 9-11.

1934. Doliolina claudiae, Chen, Palaeontologia Sinica, Ser. B, vol. 4, no. 2, 99-100, pl. 16, figs. $13-20$.

1936. Doliolina claudiae, Huziмoтo, Sci. Rep. Tokyo Bunrika Daigaku, Sect. C, vol. 1, no. 2, p. 104-105, pl. 21, figs. 4-9.

1958. Misellina claudiae, Toriyama, Mem. Fac. Sci., Kyushu Univ., Ser. D, vol. 7, p. 208-211, pl. 38, figs. 1-17.

1960. Misellina claudiae, Kanuma, Bull. Tokyo Gakugei Univ., no. 11, p. 64-65, pl. 11, figs. 2-9.

? 1957. Misellina cf. claudiae, Koвayashi, Sci. Rep. Tokyo Kyoiku Daigaku, Sect. C, vol. 5, no. $48,296-297$, pl. 1 , fig. 19. 
? 1958. Misellina claudiae, SAKAGAMI, Jour. Hokkaido Gakugei Univ., vol. 9, no. 2, p. 89-90, pl. 4, figs. 1,2 .

? 1961. Misellina aff. claudiae, Nogami, Mem. Coll. Sci. Univ. Kyoto, Ser. B, vol. 28, no. 2, p. 169-171, pl. 7, figs. 7-9.

Types. - One of DePrat's syntypes, illustrated as figure 5 of his pl. 4, has been designated by Torryama (1958, p. 209, footnote) as the lectotype of this species.

Material. -A number of sectioned-specimens were examined, several of which are illustrated in this paper. Many of the specimens are slightly or largely replaced by secondary mineralization.

Descriptive remarks. - As this species has been identified by many workers with detailed descriptions from China and several districts of Japan, no further description is needed. But as indicated by Torryama (1958), it shows considerable variation in the proloculus size, the rate of expansion of the shell and the development of the parachomata. The Kozaki specimens well agree with DePRAT's types in many important characters, but they have a little thicker spirotheca and fewer septa for the corresponding volutions. Another difference is seen in that in many of the specimens the axis of coiling of the inner one or two volutions is at normal or a large angle to that of the outer ones. In some specimens the third and occasionally the fourth volution are also coiled at a fairly large angle to the axis of the outer volutions. This type of coiling is also seen in some of the Akiyoshi specimens as described and illustrated by Toriyama (1958), but in the Kozaki specimens it is more remarkable. The Kozaki specimens well agree with the Akiyoshi specimens also in the thickness of spirotheca, but the Kozaki and the type specimens have a smaller proloculus than that of the Akiyoshi specimens.

Occurrence. - So far as is known in Japan, $M$. claudiae has a short stratigraphic range, being mostly restricted to a unit just below the Neoschwagerina simplex zone. In Akiyoshi it occurs just below the Parafusulina kaerimizensis zone, the main part of which is correlated with the $N$. simplex zone. It is associated with Nagatoella orientis (Ozawa, 1925) or $N$. kobayashii (ToriYama, 1958) there. Kanuma (1960) reported the species from the southern Mino mountains in association with $N$. cf. simplex and Parafusulina sp. Kobayashi (1957) identified the species, though it is based on only one incomplete specimen, from the Ibukiyama Limestone, central Japan. It occurs there from the upper part of the Pseudofusulina ambigua zone which lies under the horizon of Parafusulina kaerimizensis. M. claudiae described by SAKAGAMI (1958) from the Kwanto massif can not be available to know the range of the species because of its occurrence in a conglomerate. Fujimoto (Нuzimoto, 1936) identified this species from two localities of the Kwanto massif, Katsuboyama and Asakaido (Asamido). It was mentioned that in the latter locality the species is associated with $N$. craticulifera, Pseudofusulina ambigua and $P$. japonica, but as I already noted(KANMERA, 1957 ) the $M$. claudiae limestone is a limestone-conglomerate containing limestone pebbles from various horizons with Misellina, Neoschwagerina, Triticites, and Fusulinella. At Katsuboyama the species is associated with Misellina minor and Fusulinella sp., therefore, it is highly probable that the limestone containing them is also a conglomerate.

In China the species has been known from the lower part of the Swine Limestone (Chen, 1934), but no other fusuline has been known to occur together with it.

The Kozaki specimens occur abundantly in the limestones of the $b$ member of the lowest part of the Kozaki formation, and the associated species are listed in Table 8. 
Thus so far as is known, M. claudiae defines a restricted stratigraphic zone just below the Parafusulina kaerimizensis zone or the Neoschwagerina simplex zone.

Genus Neoschwagerina YABE, 1903

Type-species. - Schwagerina craticulifera ScHWAGER, 1883

Synonymy. - Gifuella Honjo, 1959

Diagnosis. -See Thompson, 1948, p. 63; Kanmera, 1957, p. 48-51

Remarks. -Recently Honjo (1959)*established the genus Gifuella from the Akasaka Limestone with G. gifuensis as the type-species. He asserted that Gifuella is distinguished from Neoschwagerina in having "small transverse septula of which the two sides run parallel in outer volution", finer "axial organs" than in other related genera, and much elongate shell. In comparing the species with such inflated or rounded Neoschwagerina as $N$. haydeni Doutkevitch or $N$. margaritae DePRAT, the distinction between them may be fairly apparent. However no remarkable difference not only in the shape of the shell but also in the structure of the septula can be seen between $G$. gifuensis and the type-specimen of $N$. craticulifera. Kanuma (1960) synonymized Gifuella to Neoschwagerina. I am also rather inclined to regard the former as a synonymy of the latter, but it may be convenient to leave it as a subgenus of the latter until the phylogeny of the Neoschwagerininae is well understood.

Regarding the distinction of the genus Cancellina from the genus Neoschwagerina, if we take "the absence of well-marked spiral septula" originally diagnosed by HAYDEN as an important criterion, $N$. simplex Ozawa must be referred to Cancellina. As I (1958) already pointed out, however, the best solution for distinguishing them from each other would be the difference in thickness of spirotheca, septula, and shape of parachomata.

\section{Neoschwagerina simplex OzAwA}

Pl.13, figs. 1-6; Pl.14, figs. 1-6; Pl.19, fig. 15

1927. Neoschwagerina simplex OzaWA, Jour. Fac. Sci. Imp. Univ. Tokyo, Sect. II, vol. 2 , no. 3, p. 153-154, pl. 34, figs. $7-11,22,23$; pl. 37, figs. 3a, 6 a.

? 1934. Neoschwagerina cf. simplex, Doutкevттсн and Kнавокоv, Acad. Sci., U. S. S. R., vol. 7 , pl. 2, figs. 4,5 .

1956. Neoschwagerina simplex, Chen, Palaeontologia Sinica, N.S., vol. 6, no. 2, p. 5556, pl. 12, figs. 13, ?14, 16 [not fig 15].

1957. Cancellina sphaerica M.-MACLAY, Uchenye Zariski Lgu, no. 225, p. 122-123, pl. 5, fig. 1 .

1957. Neoschwagerina cf. simplex, Kanmera, Mem. Fac. Sci., Kyushu Univ., Ser. D, vol. 6 , no. 1 , pl. 20, fig. 1 [without description].

1959. Neoschwagerina simplex, Honso, Jour. Fac. Sci., Hokkaido Univ., Ser. 4, vol. 10, no. 1 , p. $139-142$, pl. 3 , figs. $1,4,5$; pl. 4 .

* Honso (1959) described G. amicula from a very close locality and horizon to those of $G$. gifuensis in the Akasaka Limestone. So far as is understood from his paper, G. amicula seems to be probably an immature representative of $G$. gifuensis. Both forms are very akin to $N$. douvillei Depart, and may be better treated as a subspecies of the latter. 
1959. Neoschwagerina sphaerica, Honso, Jour. Fac. Sci., Hokkaido Univ., Ser. 4, vol. 10, no. 1, p. 159 , pl. 3 , fig. 3.

1960. Neoschwagerina cf. simplex, KanUma, Bull. Tokyo Gakugei Univ., vol. 11, p. 6768, pl. 11, figs. $1,10,11$.

1962. Neoschwagerina simplex, SUYARI, Jour. Gakugei, Tokushima Univ., Nat. Sci., vol. 12 , p. 36 , pl. 11 , fig. 1.

Lectotype. - The specimen illustrated as fig. 8 (axial section) of OzAwA's pl. 36 (1927), designated by Honjo (1959).

Material. - A number of sectioned specimens are referred to this species, several of them are illustrated for the sake of accuracy of my identification.

Descriptive remarks. - The specimens under consideration are confidently referable to $N$. simplex on the result of direct comparison of them with the original types from Akasaka. They are quite identical with the types in their small, spherical to subspherical shell, wide parachomata developed throughout the shell, thick septa, wide and short transverse septula, and rudimentary developed axial septula which rarely occur only in the outer volutions as a broad swell of the keriotheca of the spirotheca.

Honjo (1959) identified some specimens from the Akasaka Limestone with $N$. simplex. Of those, the specimen of a sagittal section (pl. 3, fig. 5) has well-developed axial septula in the third to the outer volutions, and, according to his description, occasionally has two axial septula in the outermost volution. Such well-developed axial septula are never seen in the original types of this species and in many topotype specimens collected by myself.

The specimen (pl. 3, fig. 3) described by Honjo (1959, p. 159) under the name of $N$. sphaerica (M. - MAcLAy) is probably referable to $N$. simplex. Honjo distinguished the specimen, which is partly deformed and slightly obliquely sectioned, from $N$. simplex in having a spherical shell, but OzAWA's original types (1927, pl. 34, figs. 8 , 11) of $N$. simplex are as spherical as HoNjo's specimen. No other distinction is seen between $N$. simplex and his $N$. sphaerica.

Recently Morikawa and Isomi (1961) synonymized $N$. simplex to $N$. rotunda DEPRAT which was originally described as a variety of $N$. craticulifera (Schwager), but the types of $N$. simplex rarely has a rudimentary axial septulum between the septa only in the outermost one or two volutions. While $N$. rotunda has a welldeveloped axial septulum even in the early intermediate stage of ontogeny. The former has fewer volutions than the latter.

$N$. simplex identified by CHEN (1956) from the Maok'ou Limestone of Kwangsi Province of China includes a similar problem. His specimen from Shangchin, illustrated as fig. 15 of plate 12, has a well-developed axial septulum between the septa in the fourth to the outer volutions, and apparently belongs to a different species. The specimen of fig. 14 of the same plate from the same locality may also be distinguished.

M. -MACLAY (1957) distinguished "Cancellina" sphaerica from $N$. simplex, but such difference as stressed by him on the size and the form ratio can not be seen between the two species. I am inclined to regard the former as a synonymy of the latter.

Occurrence. - Abundant in the limestone bodies of the d, e, and $f$ members. The associated species are shown in Table 8. 
Subfamily Sumatrininae KAHLER and KAHLER, 1946

Genus Cancellina HaYden, 1909

Type-species. - Neoschwagerina primigena HAYDEN, 1909

Diagnosis. -See Thompson, 1948, p. 62; KanmerA, 1957, p. 48-51

Cancellina tenuitesta sp. nov.

Pl.13, figs. 7-13; P1.19, figs. 16,17

Material. - Holotype, GKD 12292 (P1.13, fig. 7); paratypes, GKD 12097 (Pl. 13, fig. 8), 12111 (Pl. 13, fig. 9), 12110 (Pl. 13, fig. 10), 12115 (Pl. 13, fig. 11) from loc. $\mathrm{Km} 7574$ in Mameguri-dani; 12345 from loc. $\mathrm{Km} 5216$ in Uminoura; 12471 (Pl. 19, fig. 17), 12469 (P1. 19, fig. 16) from loc. $\mathrm{Km} \mathrm{5107,} \mathrm{west} \mathrm{of} \mathrm{Oshino.}$

Description. -Shell small, ellipsoidal; with rather narrowly rounded poles. Lateral slopes straight or slightly convex. Shell tightly coiled and expands uniformly; Shell of $9-9 \frac{1}{2}$ volutions attains 2.9 to $3.1 \mathrm{~mm}$ in length and 1.6 to $1.95 \mathrm{~mm}$ in diameter.

Proloculus ranges between 80 and 180 microns in outside diameter. Inner few chambers have a short axis of coiling, and probably at the first half volutions it attains a globular shape. Succeeding volutions increase rapidly more in length than in height and the mature shape of the shell is established by the fifth volution which has a form ratio of 1.9 to 2.0 . Inner 3 volutions expand very slowly; in many of the examined specimens the second volution is lower in height than the first one. Heights of chambers nearly the same throughout the length of the shell except in polar regions.

Spirotheca thin, composed of a tectum and a finely alveolar keriotheca. Upper surface of tectum covered with a thin or thick dense layer which is continuous with parachomata. Lower surface of alveolar layer thinly lined with the same deposit. Thickness of spirotheca measured in midway between two adjacent transverse septula in middle part of shell is $6-8$ microns in inner 2 volutions, $10-12$ microns in third to fifth, and 12-15 microns in outer volutions, and never exceeds 16 microns.

Primary transverse septula well developed throughout shell except in first volution; characteristically very thin. In cross-section of septula alveoli walls become thicker and more widely spaced in lower area than in upper area where they are thin and closely spaced. No secondary transverse septula. No distinct axial septula are present, but short and broad extension of keriotheca of spirotheca are rarely and sporadically developed. They are restricted to immediately lateral sides of transverse septula and never occur in central part of chambers.

Septa also thin in central part between a pair of transverse septula, but become thicker as they approach to transverse septula. Their distal margins extend forwards at a fairly large angle, and are densely coated with the same material as parachomata.

Parachomata well developed throughout shell except in first several chambers of first volution; high, narrow, extending up to the two-thirds the heights of chambers and are in contact with lower ends of transverse septula, but under the lateral passages they are low and triangular in cross-section.

Foraminae small, circular in cross-section.

Remarks. - This new species is closely allied to Praesumatrina schellwieni (DEPRAT) in essential features, but is different from the latter in lacking secondary transverse 
septula and axial septula. In the original figures of the syntypes of $P$. schellwieni (DEPRAT, 1913, pl. 8, figs. 4-9) the secondary transverse septula and axial septula can be clearly recognized in the fourth volution to the outer ones. C. tenuitesta and $P$. schellwieni are possibly directly related to each other in one and the same evolutionary lineage, and the former may probably be ancestral to the latter.

C. tenuitesta is also very similar to Praesumatrina primitiva M. -MACLAY described from the P2 bed of Crimea, but it has a thinner spirotheca, thinner septula, and a more closely coiled shell.

C. tenuitesta somewhat resembles C. neoschwagerinoides (DEPRAT) but differs in having less massive parachomata and thinner transverse septula.

Occurrence. - Common in the e and f members at locs. $\mathrm{Km} 1696$ and $7574 \mathrm{a}-\mathrm{d}$, e, and also rarely found at locs. 5007, 5216, and 5107. Associated species are listed in Table 8 .

\section{Notes on stratigraphy}

The Kozaki formation is distributed in narrow strips along four fault zones of NEE-SWW direction in the lower course of the Kuma river. Regarding its distribution, stratigraphic sequence, facies, geologic relations to other rock units and its significance in geotectonic history the reader may refer to my previous paper (KANMERA, 1961; in Japanese with English resumé). The characteristic features of the sediments of the Palaeozoic formations in this area have been concisely described in Notes on the Chichibu geosyncline (FuJII, KANMERA, and Matsumoto, 1962) as an appendix to Petrography of the upper Palaezoic sandstones from the Yatsushiro area, Kyushu (FUJIr, 1962). In the following pages, thererfore, only brief accounts are given on the stratigraphy of the Kozaki formation and on the lithology of the limestones from which the described fusulines were collected.

The Kozaki formation is typically exposed in the area north of Kozaki and adjacent places near Sakamoto, Kumamoto Prefecture (see Fig. 2). It is divided into two subformations (see Fig. 3). The lower subformation (180-200 m) consists mainly of alternating black slate (b, $d, f$ members) and cobble-bearing conglomerate with intercalated sandstone (a, c, e members), and is accomapnied with dark grey to black lenticular limestone at four horizons ( $b, d, e, f$ members). The upper subformation (180-220 m) comprises thick conglomerate in the basal part ( $\mathrm{g}$ member), siltstone and slate with subordinate sandstone in the middle part (h member), and predominant black slate with a few thin chert and a small lenticular limestone in the uppermost part (i member).

The bodies of limestone are small and lenticular, mostly less than $7 \mathrm{~m}$ thick, except for one which attains $15 \mathrm{~m}$ thick, with only a little broader extension. They mostly have no virtual stratification plane, but sometimes exhibit clear lamination owing to the difference in grain-size of the material.

In the lower subformation the limestone is highly fossiliferous unlike the surrounding rocks. It is bioclastic, coarse calcarenite to calcirudite consisting mainly of remains of calcareous algae, crinoid oscicles, fusulines, and subordinately of small foraminifer, ceramoporoid bryozoas and hydrocorallines. Small gastropod and bra- 


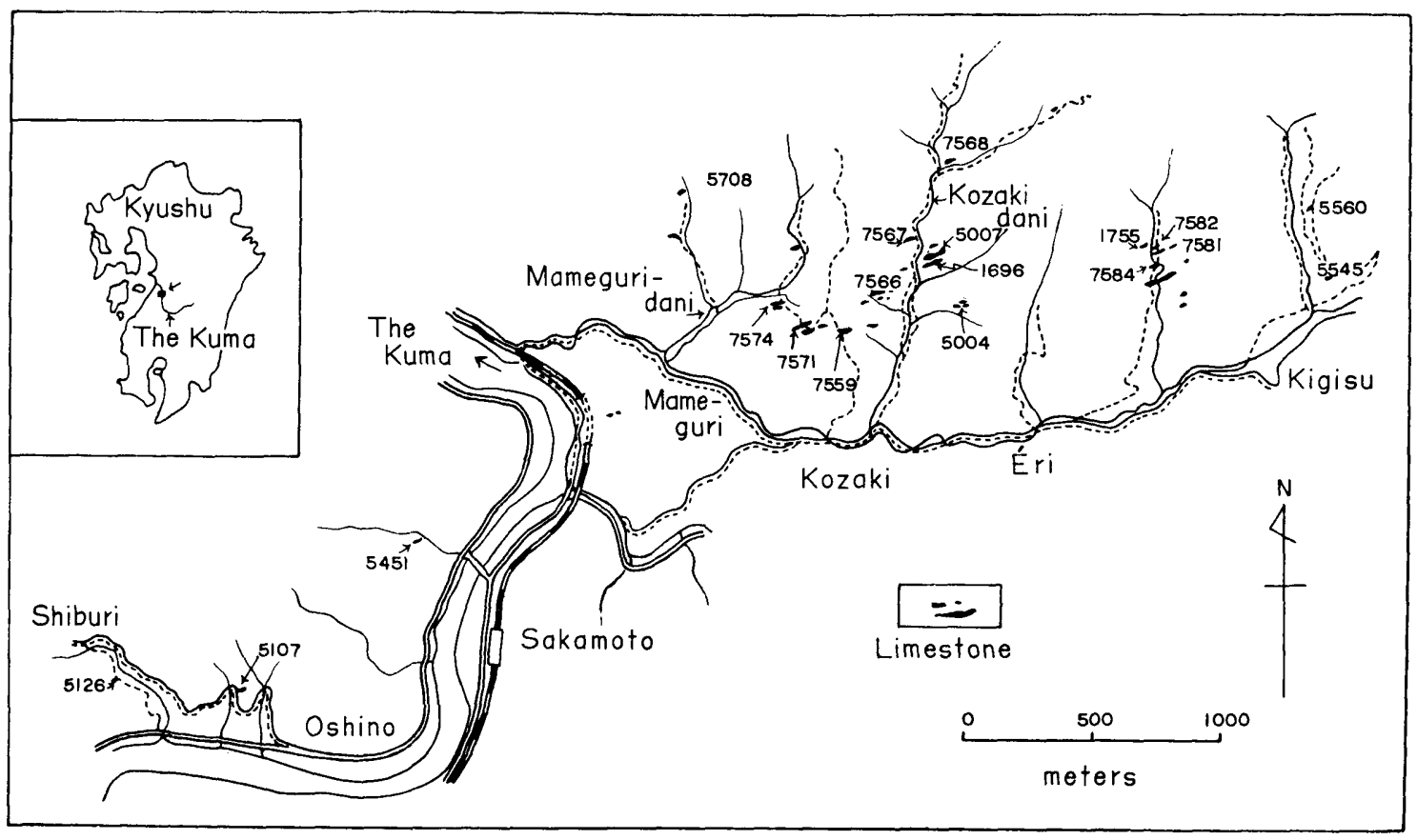

Fig. 2. Map of the Sakamoto area along the Kuma river, showing collecting localities of the fusuline limestone in the type area of the Kozaki formation.

chiopod shells and echinoid spines are not uncommonly met with.

Crinoid columns and plates and fusulines are quantatively most abundant in many bodies of the limestone. Algal remains which are equally important constituents include dasycladaceans and codiaceans belonging to some genera and encrusting spongiostromids.

The limestone, except oolite which occupies small parts of some bodies, essentially had a lime-mud and very fine-grained lime-sand matrix, but not a small part of the matrix has been secondarily recrystallized to mozaic sparry calcite.

A majority of the fossil remains, especially crinoids, is fragmental and more or less abraded, indicating clearly transportation from the near-by living sites. However, algal remains are well-preserved in general and includes many unbroken thalli, presumably suggesting in situ deposition. Many bodies of the limestone of the a and b members contain algal bands of less than $40 \mathrm{~cm}$ in thickness, which are exclusively crowded with unbroken thalli of Gymnocodium kanmerai KoNISHI or with stromatolite pisolites. These are probably in growth position.

In addition to these algal bands, spongiostromid algae played the important role as a frame-builder in the accumulation of loose bioclastic fragments. Thin sections reveal that many of the organic debris are encrusted or traped by laminae or films of spongiostromid algae, being grouped into composite accretions of various shape and size (less than $10 \mathrm{~mm}$ ). These accretions are coalesced at places with the neighbouring ones by extended arms of algal laminae or films. The matrix is rather wide and consists mostly of a lime-mud. The algae are never seen to coalesce into large discs or sheets. 


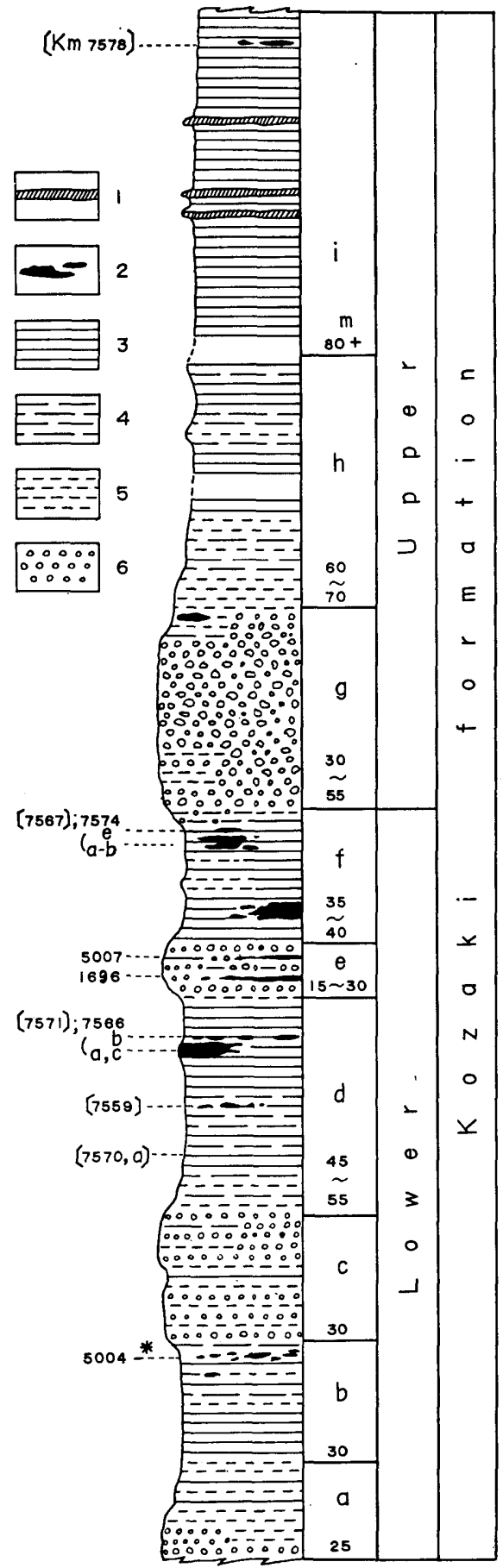

Fig. 3. Generalized section of the Kozaki formation in the type area. The localitynumbers shown in this section are those of Mameguri-dani [in square brackets] and Kozaki-dani. [* The limestone at loc. Km 5002 shown in my previous paper (in Japanese) is considered as an erratic boulder]

1. chert; 2. limestone; 3 . slate; 4. alternating slate or siltstone and sandstone; 5 . sandstone and silty sandstone; 6 . conglomerate. 
Most bodies of the limestone are slightly carbonaceous and are more or less argillaceous or arenaceous with angular, fine-grained quartz sand. The limestone of the c member includes fairly well-sorted fine-grained calcarenites with thin bands of oolite which has a sparry calcite matrix.

A mound-like attitude of the limestone body is similar to that of a patch reef or a reef knoll, but is never provided with the real internal features of the reef. There is nothing to indicate that the limestone was a wave-resistant mass at the time of deposition. It is probable that there were discontinuous or patchy spreads of organic debris on which the algae of such kinds as mentioned above favourably had grown. Many of the debris formed the base of attachment for an algal thallus or lamina, and thus algal growths and accumulation of other organic remains which were probably mostly derived from near-by living sites were in intimate association. However the condition was not so favourable for the algae as to form large masses of colonies because perhaps the accumulation of bioclastic debris was too rapid.

\section{Fusuline faunas of the Kozaki formation}

Many of the limestone of the lower subformation in the type area carry rich and varied fusulines, and the species tabulated in Table 8 have been identified. As is well displayed in this table, two distinct assemblage of species can be recognized. In its lower part the species listed below are diagnostic:

Misellina claudiae (DEPRAT)

Nankinella kozakiensis KANMERA

Sphaerulina crassispira japonica KanMERA

Minojapanella sp. nov. (?)

Toriyamaia laxiseptata $\mathrm{K}_{\text {ANMERA }}$

Nagatoella sp.

Parafusulina (Skinnerella) gruperaensis Thopson \& MiLLER

$P$. (S.) figueroai Thompson \& Miller

$P$. (S) nakamigawai Morikawa \& Horiguchi

Monodiexodina kumensis KANMERA

Of these the first three species and $P$. (S.) gruperaensis are especially abundant in many limestone bodies of the lower part. The former species are significant for the comparison with the Chihsia faunas of China, and the latter, together with $P$. $(S$. figueroai, serve as a good basis for correlation with the Permian of Central America.

Selecting $M$. claudiae as the name-fossil, the lower part (b to the lower part of $\mathrm{d}$ member) of the lower subformation is designated as the $M$. claudiae zonule. It should be noticed that such species of Parafusulina as $P$. (S.) nakamigawai and Monodiexodina kumensis, which have a large and elongate shell and well-developed cuniculi, occur in this zonule.

The following species are diagnostic of the upper part of the lower subformation:

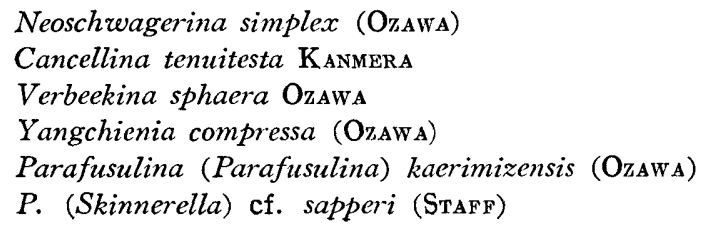


Table 8. Distribution of the fusuline species from the lower subformation of the Kozaki formation.

\begin{tabular}{|c|c|c|c|c|c|c|c|c|c|c|c|c|c|c|c|c|c|c|c|c|c|}
\hline \multirow{3}{*}{ Horizon (member) } & \multirow{2}{*}{\multicolumn{5}{|c|}{5004}} & \multirow{3}{*}{\begin{tabular}{|c|}
$\mathrm{b}$ \\
7582
\end{tabular}} & \multirow{3}{*}{$\frac{\mathrm{b}}{7584}$} & \multirow{2}{*}{$\frac{b}{5200}$} & \multirow{2}{*}{$\mathrm{b}$} & \multirow{2}{*}{ d I } & \multirow{3}{*}{$\frac{\mathrm{d}}{\mathrm{I}}$} & \multirow{2}{*}{ d I } & \multirow{2}{*}{\multicolumn{3}{|c|}{$\frac{d}{7566}$}} & \multirow{3}{*}{$\frac{\mid \mathrm{e}}{5007}$} & \multirow{2}{*}{$\mathrm{e}$} & \multicolumn{2}{|c|}{ f } & \multirow[t]{2}{*}{ f } & \multirow{2}{*}{$\mathbf{f}$} \\
\hline & & & & & & & & & & & & & & & & & & 75 & & & \\
\hline & $\mathrm{b}$ & $\mathrm{d}$ & $\mathrm{g}$ & $\mathrm{h}$ & $\mathrm{j}$ & & & & & & & & $\mathbf{a}$ & c & b & & & $\overline{a-d}$ & $\mathrm{e}$ & & 1568 \\
\hline 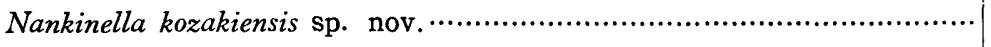 & $\times$ & & & (2) & & 0 & 0 & & $x$ & $x$ & $x$ & & $x$ & $x$ & & & & & & & \\
\hline 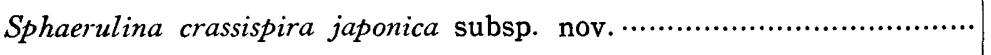 & & & & $\times$ & O & 0 & ○ & & & & & & & $x$ & & & & & & & \\
\hline 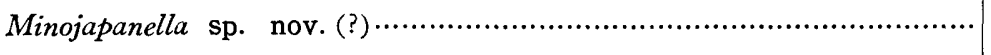 & $\times$ & & & & & & & $\mathrm{O}$ & & $\times$ & & $x$ & & & & & & & & & \\
\hline 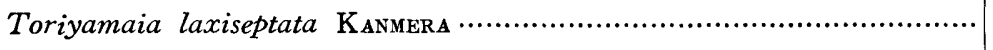 & & $x$ & & & $x$ & & & & & & & & & & & & & & & & \\
\hline 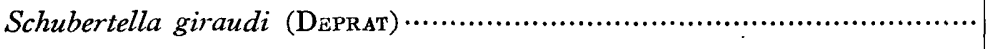 & & & O & $\mathrm{O}$ & $x$ & $x$ & $x$ & & $x$ & & & & & $x$ & & $x$ & $x$ & & & & \\
\hline 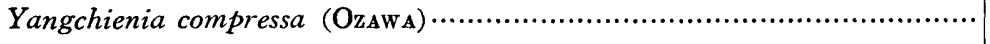 & & & & & & & & & & & & & & & $x$ & 0 & 0 & $x$ & $x$ & $x$ & $\times$ \\
\hline 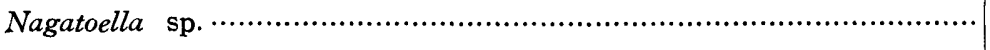 & & $x$ & & & (2) & & & & & & & 0 & & & & & & & & & \\
\hline Schwagerina? sp. cf. "Pseudofusulina" chihsiaensis (LEE) ….................. & & & & & & & & & & $\times$ & & & & & & $x$ & & $x$ & & & \\
\hline Parafusulina (Skinnerella) gruperaensis (THOMpson \& MLLLER) ................ & & & & O & & 0 & (2) & & & O & $?$ & & () & ○ & & & & & & & \\
\hline 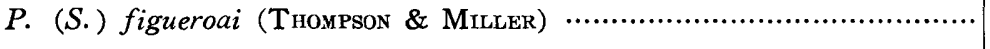 & & & O & & & & & & & & & & & & & & & & & & \\
\hline 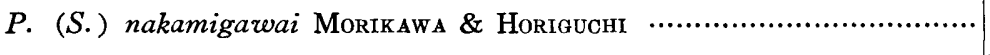 & $\times$ & & & & & & $?$ & ○ & & & & & & & & & & & & & \\
\hline$P . \quad(S$.$) sapperi (STAFF)$ & & & & & & & & & & & & & & & & $\times$ & & 0 & & O & \\
\hline 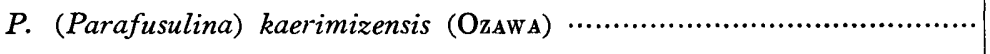 & & & & & & & & & & & & & & & 0 & ○ & () & 0 & & $\times$ & (2) \\
\hline 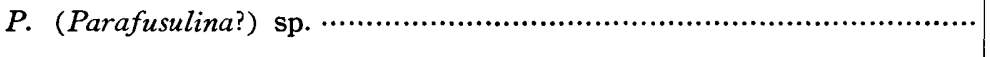 & & & $x$ & & & & & O & & & & & & & & & & & & & \\
\hline 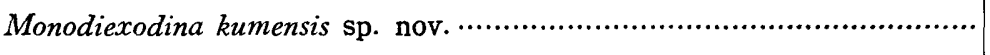 & 0 & & & & & & & & & & & & & & & & & & & & \\
\hline 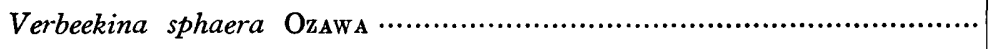 & & & & & & & & & & & & & & & O & ( ) & O & 0 & & $x$ & $\times$ \\
\hline 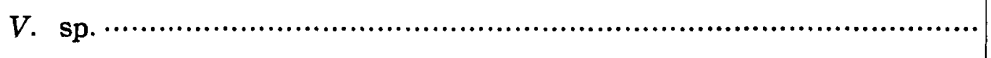 & & & & & & & & & & & & & & & $\times$ & & & & $\times$ & & \\
\hline Pseudodoliolina aff. pseudolepida pseudolepida (DePrat) $\ldots$ & & & & & & & & & & & & & & & & & & 0 & $\times$ & & \\
\hline 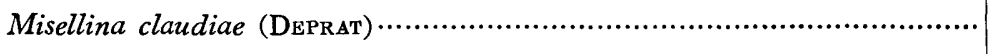 & & $\mathrm{O}$ & & & (2) & 0 & (-) & & $x$ & $x$ & & 0 & 0 & 0 & & & & & & & \\
\hline 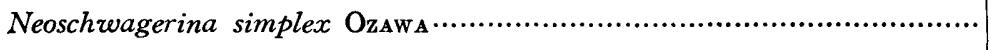 & & & & & & & & & & & & & & & O & ○ & () & ○ & O & 0 & 0 \\
\hline 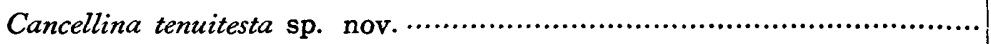 & & & & & & & & & & & & & & & & $\times$ & 0 & 0 & 0 & $x$ & \\
\hline
\end{tabular}

Explanation: ( ) abundant; $O$ common; $\times$ rare; ? identification uncertain See figs. 2 and 3 for the collecting localities. 
Also Pseudodoliolina pseudolepida pseudolepida (DEPRAT) and Verbeekina sp. compose significant elements of the faunule.

$N$. simplex, which has no axial septula, is one of the smallest and simplest form of the genus Neoschwagerina (KANMERA, 1957) and so is $V$. sphaera in the genus Verbeekina (SugI, 1960). C. tenuitesta is a probable ancestor of Praesumatrina schellwieni from which it differs in having neither secondary transverse septula nor axial septula. The specimens allied to $P$. pseudolepida pseudolepida are much smaller than the types of the species and exhibit characters indicating its predecessor. This unique assemblage comprising the most primitive species of each of these four genera well defines the faunule of the lower subformation of the Kozaki formation, being very useful for the correlation.

The most reliable zonal subdivision should be defined with a group of species whose successive evolutionary positions are well understood. The Neoschwagerininae is one of the groups best suitable for this purpose. The zonal scheme established by OzAwa (1927) on the basis of the neoschwagerines in the Akasaka Limestone is a good example, and is still available for the subdivision of our middle Permian rocks (see page 79).

As is well understood from the assemblage of species mentioned above, the upper part of the lower subformation of the Kozaki formation is safely correlated with the $\mathrm{Nn}$ zone of the Akasaka Limestone. Ozawa selected Cancellina nipponica as the name-fossil of the zone, but it belongs to a different evolutionary series from the name-fossils of the succeeding zones (KANMERA, 1957), that is, $N$. craticulifera, $N$. margaritae and Yabeina globosa and, furthermore, its occurrence is rare, being recorded, so far as is known, from only a few localities at and near Akasaka. On the other hand Neoschwagerina simplex, which has nearly the same stratigraphic range as $C$. nipponica in the Akasaka Limestone (OzAwa, 1927; Honjo, 1957), has been found in many areas of the Japanese Islands and in China, and its closely related, if not identical, species have been known in several regions in Middle East. It probably belongs to the same evolutionary series of the name-fossils of the upper zones. It can define the lowest part of the so-called Neoschwagerina zone. It is, therefore, better to denominate that part as the $N$. simplex zone (KANMERA, 1958) in place of the $C$. nipponica zone.

The lower part ( $\mathrm{g}$ and $\mathrm{h}$ members) of the upper subformation in the type Kozaki area is unfossiliferous, but the equivalent beds $(h)$ in the Fukami belt contain a small limestone lens carrying the following fusuline species:

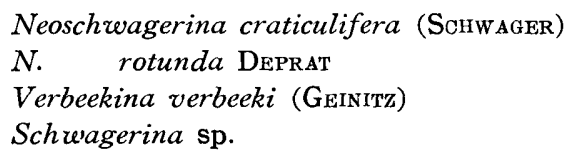

In the Haki belt Afghanella sp. is found in the same member (h). Thus, the species of Neoschwagerina and that of Verbeekina of this part are more advanced than those of the $N$. simplex zone. This assemblage of species well agrees with that of the $N$. craticulifera zone (Nc) of the Akasaka Limestone. Therefore the lower part of the upper subformation is referable to the $N$. craticulifera zone.

In the uppermost part of the Kozaki formation there occurs a white-grey small lenticular limestone from which the following species have been identified.

Yabeina globosa (YABE)

Neoschwagerina minoensis DEPRAT 
N. margaritae DEPRAT

Schwagerina sp.

$Y$. globosa and $N$. minoensis are the characteristics of the $\mathrm{Ng}$ zone of the Akasaka Limestone (Ozawa, 1927; Honjo, 1959), and N. margaritae is the leading species of the underlying $\mathrm{Nm}$ zone and has been known to range up into the $\mathrm{Ng}$ zone. The limestone is, therefore, referable to the lower part of the Yabeina globosa zone $(\mathrm{Ng})$.

Summarizing the above the Kozaki formation ranges from the Misellina claudiae zone, which is equivalent to the Pseudofusulina ambigua zone, in its lower part to the Yabeina globosa zone in its upper part. The Neoschwagerina simplex zone in the upper part of the lower subformation defines the lower part of the so-called Neoschuagerina zone.

\section{Correlation}

\section{A. Correlation within the Japanese Islands}

As stated in the foregoing chapter, the lower subformation of the Kazaki formation represents two distinct zonules, the Misellina claudiae and the Neoschwagerina simplex zonule. The assemblage of the species of each zone enables us to identify them easily and trace them widely in the lower Middle Permian of Japan and also of related regions. The distribution map of the $N$. simplex zone in Japan was shown in my previous paper (1961, fig. 4, in Japanese). I give in this chapter accounts on some important formations carrying the same assemblage of species or the comparable fauna as those of the Kozaki formation and on the relationship between the zonation in terms of species of the Neoschwagerininae and Schwagerininae.

In the Inner Zone of Southwest Japan there occur several large and thick limestone masses, in which a complete or nearly complete succession of the Lower and/or Middle Permian is seen. Of those the Akiyoshi, Atetsu, Ibukiyama, and Akasaka Limestones have been well studied. Table 9 shows the zonal subdivision and correlation between the type sections of the Permian of these limestones with references to the Kozaki and other formations in the Kuma area.

The assemblage of the species of the $N$. craticulifera zonules of five areas are quite identical and the zonules are safely correlated with one another.

The equivalence between the Pseudofusulina ambigua zonule of Akiyoshi and Ibukiyama and the Pseudofusulina kraffti magna zonule of Atetsu has been already indicated by NogAmI (1961) mainly on the basis of the species of the Schwagerininae. Here a question remains about the relation between the species assemblage of the Schwagerininae and that of the Neoschwagerininae. The lower part of the zonules under consideration contains, besides the name-fossils of the zonules, not a few species of Pseudofusulina and Schwagerina, such as $P$. vulgaris with its several subspecies, and even some species of Triticites ranging up from the lower subzone. The species of Schwagerina and Pseudofusulina of the zonules are in general apparently more primitive than those of the lower part of the Kozaki formation, having a smaller shell and a weaker septal fluting. However the schwagerinines of the upper part of the $P$. ambigua zonule of the Atetsu Limestone are no longer associated with the species of Triticites, and include species which are very similar to those of the lowest part of the Kozaki formation. For example, Schwagerina semilucera semilucera, S. semilucera granda, and Nagatoella kobayashii which are very close to 
Parafusulina (Skinnerella) figueroai, P. (S.) gruperaensis, and Nagatoella sp., respectively. Misellina claudiae is also accompanied in this part of both formations. In the upper part of the $P$. ambigua zonule of the Ibukiyama Limestone there occur Misellina cf. claudiae, Cancellina sp., Schwagerina japonica, and Schubertella giraudi (Kobayashi, 1957). In the Akiyoshi Limestone there is a distinct bed of M. claudiae which occur in association with Nagatoella kobayashii and Nankinella nagatoensis at the top of the $P$. ambigua zonule.

Thus the upper part of the $P$. ambigua zonule and that of the P. kraffi magna zonule are characterized by $M$. claudiae and/or $N$. kobayashii, and is correlated with the lowest part of the Kozaki formation, that is, the $M$. claudiae zonule.

The earliest representative of Misellina known in Japan is $M$. ibukiensis which was first recorded from the middle part of the $P$. ambigua zonule of Ibukiyama together with $P$. aganoensis, S. gümbeli, etc. (KoBAYASHI, 1957). MorIKawa and Isom (1961) indicated that this species have a wide range from the upper part (the Acervoschwagerina endoi zonule) of the Pseudoschwagerina zone to the "Neoschwagerina zone".

Thus the uppermost part of the Pseudoschwagerina zone, that is the Pseudofusulina vulgaris zone, to the Pseudofusulina ambigua zone may be called the Misellina zone. The Misellina zone may be divided into two parts, the lower $M$. ibukiensis and the upper $M$. claudiae zone, of which the former is correlated with the $P$. vulgaris zone and the lower part of the $P$. ambigua zone, and the latter with the upper part of the P. ambigua zone. Nagatoella kobayashii often occurs as an associate in the two zones. The P. ambigua zonule by OzAwA (1927) or the lower part of the lower formation by Akasaka Research Group (1956) in the Akasaka Limestone may probably be referable to the Misellina claudiae zone, although neither Misellina nor Nagatoella have been found from it.

A remark should be given here about the Cancellina nipponica zone (OzAwA, 1927).

Akasaka Research Group (Morikawa, et al. , 1956) and Minato and Honjo (1959) independently showed the zonation on the fusulines of the Akasaka Limestone, but unfortunately there are many discrepancies between them especially on the appearance, ranges, assemblages, and stratigraphic positions of the species and also on the definition of the faunules and zonules. Here I would not discuss about them, but point out the need of further detailed studies. From the reliable data available at present the $\mathrm{Nn}$ zone can be redefined by the following assemblage of species which occur in a definite stratigraphic unit below the Neoschwagerina craticulifera zone:

Neoschwagerina simplex, Cancellina nipponica (Minato and Honjo's Minoella),

Verbeekina sphaera, Yangchienia compressa, Schubertella giraudi, Schwagerina

japonica, Pseudodoliolina ozawai. (The last two species are not confined to the zone but commonly associated.)

The contemporaneity of the $N$. simplex zone of the Kozaki formation to the $\mathrm{Nn}$ zone of the Akasaka Limestone is well indicated by the existence of the identical species, that is, both are defined by a particular assemblage of species comprising $N$. simplex, C. nipponica or C. tenuitesta, Verbeekina sphaera, Yangchienia compressa, Schubertella giraudi, and Nankinella kozakiensis*.

Recently it has been made clear that several formations in the Hida-Mino massif

* See page 123, footnote. 
Table 9. Correlation of the subdivisions among selected Permian sequences in Japan

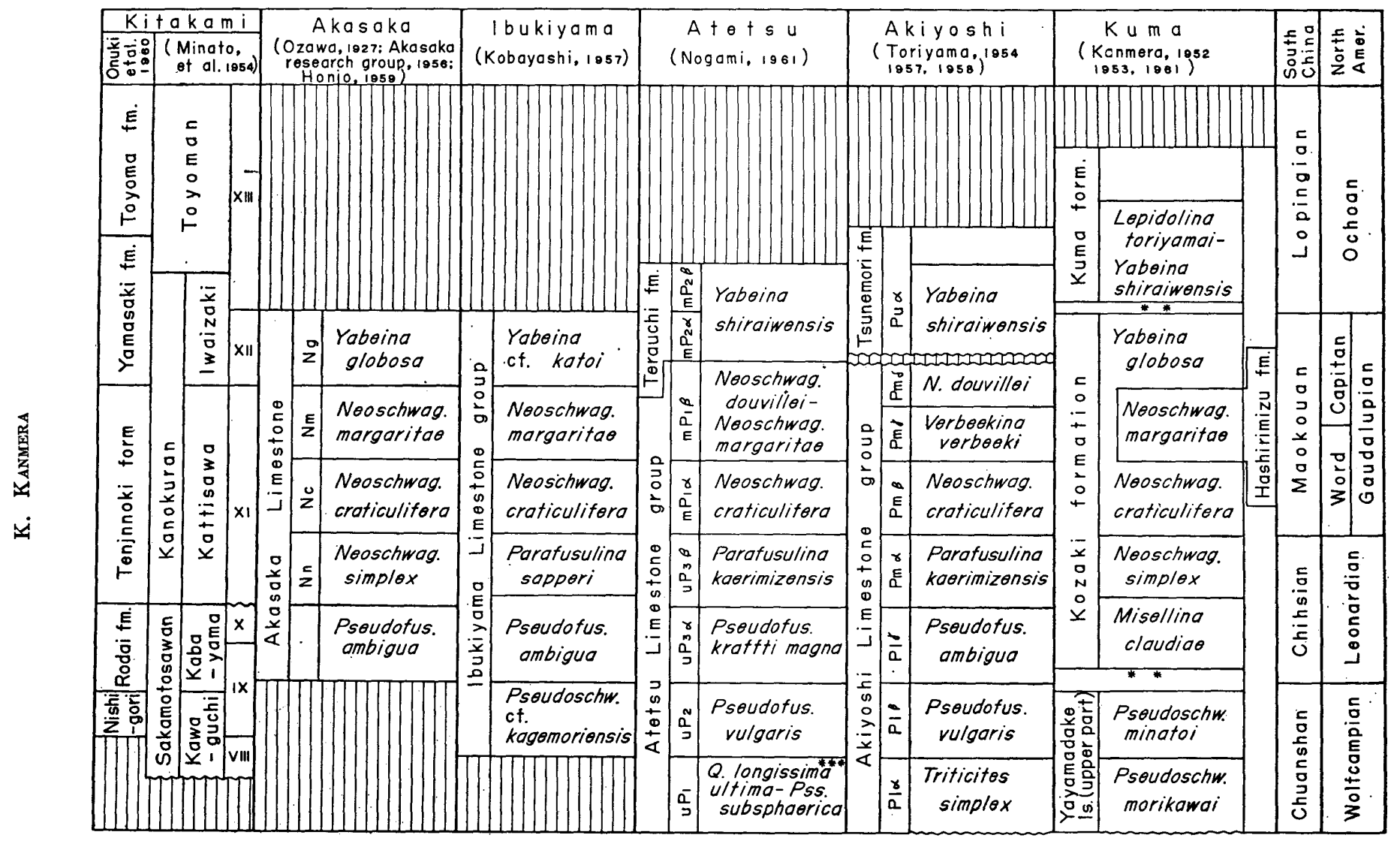

* A part of the Iwaizaki Limestone at the type locality ranges down probably to the Pseudofusulina ambigua zone.

* The original stratigraphic relation is unknown owing to the separated outcrops of the two formations above and below. 
near Akasaka contain the assemblage of species which are well comparable with the above mentioned one. They are the middle part of the Tominoho and equivalent Kuchibora formations (Kanuma, 1958), the Tokumototôge** (TANAKA, et al., 1952), the Takayama (Morikawa and Isomi, 1961), the Deguchi** (Kanuma, in Fujimoto, Kanuma, and Igo, 1962) and the Ōno formation and also a part of the Sodé** and Ōsu formations (Fujimoto, et al., 1962). The Miyakawa formation and nearby exposed equivalent in the Tamba mountains northwest of Kyoto also contain the $N$. simplex fauna (ISOMI and KurodA, 1958). These formations consist mainly of unfossiliferous slate, sandostone, chert, and basic pyroclastic rocks, and the limestone carrying the fauna under consideration occurs as a lens or discontinuous bodies. Accordingly the relation of the $N$. simplex zone to the subjacent or the superjacent zone can not be determined there. It should be noted, however, that these limestones contain such species as Parafusulina (Skinnerella) kaerimizensis, $P$. (S.) hirayuensis, $P$. (S.) japonica, Pseudofusulina ambigua, P. kraffti, etc. In some cases Misellina claudiae or Pseudodoliolina ozawai are accompanied with them. The associated schwagerinines are not always the same among the formations under consideration, but most of them are those known from the unit assigned by authors to the Pseudofusulina ambigua zone or the "Parafusulina zone".

The Parafusulina (Skinnerella) kaerimizensis zonule of the Atetsu Limestone is safely correlated with the type section of the zone in the Akiyoshi Limestone by the common occurrence of the identical species as indicated by NogamI (1961). The d, e, and $\mathrm{f}$ members of the Kozaki formation, which are characterized by the $N$. simplex assemblage(see page 121-122), contain $P .(S$.$) kaerimizensis and P .\left(S_{.}\right)$sapperi. The latter species is similar to $P$. (S.) edoensis which is diagnostic of the $P$. kaerimizensis zone. These facts indicate that the $N$. simplex zone is probably contemporaneous to the $P$. (S. ) kaerimizensis zone.

The upper part of the $P$. kaerimizensis zone of Akiyoshi contains here and there $N$. craticulifera craticulifera, $N$. craticulifera haydeni, and Afghanella ozawai (ToRIYAMA, 1957, 1958)***, which are the indices of the overlying $N$. craticulifera zone. Nogami (1961) also mentioned that Afghanella and Pseudodoliolina and primitive Neoschwagerina first appeared in this zone of Atetsu, but he did not give their specific names and did not indicate from what horizon of the zone they appeared. Anyhow, the $N$. simplex fauna has not yet been found in the Akiyoshi and Atetsu Limestones, though further study is needed for the accurate identification of the species under consideration and for the setting of their precise horizon.

The assemblage of the species of the $P$. (S.) sapperi zonule of the Ibukiyama Limestone is similar to the $N$. simplex zonule of Kozaki, comprising Neoschwagerina sp., Cancellina cf. nipponica, Parafusulina sapperi, "P. kaerimizensis"****, and Schwagerina japonica. Identical species are rather few among the $N$. simplex, $P$. sapperi, and $P$. kaerimizensis faunules, but the association of primitive or small species of Cancellina or Afghanella and Neoschwagerina in the faunules and the presence of closely related schwagerinines and also the contemporaneity of the overlying and underlying zones strongly suggest that they are of the same age.

* Ozawa did not describe any species of Nankinella from Akasaka, but many specimens very close to $N$. kozakiensis are contained in his thin-sections obtained from the Nn zone.

** Further detailed zonation or palaeontological study is necessary.

***Nogami (1961) recorded Pseudodoliolina ozawai from this zone.

**** See pages 101 and 102. 
Certain species of the Kozaki formation shed a new light on the correlation of the Lower and Middle Permian between Southwest Japan and the Kitakami massif, which has long been a subject of discussion. Monodiexodina kumensis from the $\mathrm{b}$ member of the Kozaki formation is a single example of the genus in Southwest Japan which is similar to $M$. matsubaishi(Fujnoto)*. It occurs from the Misellina claudiae zone just below the $N$. simplex zone. Monodiexodina matsubaishi, the best known and important species in the Kitakami, is said to be long-ranging**, occurring at several horizons of the upper part of the Sakamotozawa formation (the Parafusulina zone by Minato, et al., 1954, and ONUKI, 1956; the Pseudoschwagerina zone by some other authors) to the upper part (the Yabeina zone by authors) of the Kanokura formation, but it occurs most abundantly in the upper part of the former and the lower part of the latter (Minato, et al., 1954, Onuki, 1956; Fujimoto, 1956).

In the Nagasaka area of western Kitakami, the upper part of the Sakamotozawa formation is represented by the Rodai formation. Its fusuline faunule consists of the combined assemblages of species which are known from the Pseudofusulina vulgaris zone, the Pseudofusulina ambigua zone, and the Neoschwagerina zone(Codonofusiella paradoxica) (ONuKI, et al., 1960). This peculiar assemblage strongly emphasizes the necessity of further palaeontological study on the fauna, but as suggested by NogAmi (1961) the predominance of the species of Pseudofusulina in the faunule, such as $P$. ambigua and P. kraffti, indicates that the Rodai formation is probably referred to the $P$. ambigua zone. This probability is also supported by the association of Sphaerulina and Nankinella of discoides type in the formation. Species similar to them are found in the lowest part of the Kozaki formation, that is, the Misellina claudiae zonule, which, in turn, is correlated with $P$. ambigua zone as already mentiond.

Some authors assigned the lower part of the Kanokura formation to the "NeOschwagerina zone" on the basis of sporadical occurrence of unnamed species of Neoschwagerina. The precise identification of those material would enable us to confirm to what part of the "Neoschwagerina zone" (s. 1.) the formation belongs, but the evidence recognized in the underlying formation indirectly suggests that the lowest part of the Kanokura formation may be of the $N$. simplex zone. This possibility may be supported by the similarity of lithofacies between the lowest part of the Kanokura formation and the $N$. simplex zone of several areas of southwest Japan. In other words the zone is of the age of the renewed occurrence of conglomerate and coarse-grained sediments as is exemplified in the Kozaki formation.

\section{B. Relation to other regions}

The fusuline fauna closely related to the $N$. simplex fauna of the Kozaki formation can be traced westwards to South China, Crimea, and Montenegro, eastwards to Mexico and Guatemala, and northwards to Sikhote-Alin. The materials adopted as a basis for the discussion in this chapter depend entirely on the published papers of

* Outside the Kitakami this species has been identified only from a limestone pebble of the Takagami conglomerate at Chôshi, east of Tokyo (MaEda and Mitsuoka, 1961).

* This species was formerly assigned to or compared with Parafusulina wanneri (SoHwAGER), but it is not clear whether the specimens previously called $P$. wanneri can be all referred to $M$. matsubaishi or split into different species. 
authors, especially those with a monograph of species. My own view is given for the comparison of species and the inter-provincial correlation of the Middle Permian among those areas.

\section{China}

As is shown in the following table the fusuline fanna of the lower part of the Kozaki formation includes two identical and many allied species to those of the Chihsia Limestone of China. The type section of the Chihsia Limestone in the Nanking Hills comprises three distinct zones, the Misellina claudiae, Nankinella discoides, and Parafusulina multiseptata zones, in ascending order. In the middle zone Nankinella orbicularia, Sphcerulina crassispira and Yangchienia iniqua are also diagnostic, and the upper zone is accompanied characteristically with Schwagerina chihsiaensis (LeE, 1931; Chen, 1934; Chen and Sheng, 1957).

\begin{tabular}{lll} 
& \multicolumn{1}{c}{ Chihsia } & Kozaki \\
Lowest & Misellina claudiae & M. claudiae \\
Lower & Nankinella orbicularia & N. kozakiensis \\
& Sphaerulina crassispira crassispira & S. crassispira japonica \\
& Yangchienia iniqua & Y. compressa \\
Upper & Cancellina schellwieni & C. tenuitesta \\
& Pseudodoliolina pseudolepida pseudolepida & P. aff. pseudolepida preudolepida \\
& Verbeekina minor & V. sphara \\
& Parafusulina multiseptata & $P$. (Skinnerella) cf. sapperi \\
& P. constricta & $P .(S$.$) nakamigawai$ \\
& Schwagerina chihsiaensis & S. cf. chihsiaensis
\end{tabular}

Although the zonation of minor order comparable to that of the Chihsia Limestone has not been worked out in the Kozaki formation, parallel occurrence of identical or similar species can be recognized between the two formations as is seen also in Table 8. For example, $M$. claudiae is confined to the lower part, and the associated occurrence of species of Nankinella, Sphaerulina, and Yangchienia, which are respectively very close to those of the Chihsia, characterizes the lower part. The comparable species of the upper part of the two formations are, needless to remark on, quite intimate to each other.

The palaeontological evidence cited above supports the confident correlation of the $N$. simplex zone of the Kozaki formation with the Chihsia Limestone.

Despite the close similarity between the Kozaki and Chihsia faunas $N$. simplex and $V$. sphaera which are diagnostic in the former have not been found in the latter. CHeN (1956) identified $N$. simplex from the Maok'ou Limestone of Suilü, Shangchin, and Chungsan of Kwangsi, and $V$. sphaera from that of Lingyon and Shangchin. $N$. simplex from Shangchin (pl. 12, figs. 14, 15) is, I believe, different from the types of the species in having much better developed axial septula. Whereas that of Suilü and Chungsan may be identical, whether it is associated with $V$. sphaera or not is uncertain. Anyhow a certain part of the Maok'ou Limestone of the Kwangsi province which contains $N$. simplex and $V$. sphaera may be referable to the upper part of the $N$. simplex zone of the Kozaki formation, but the precise stratigraphic horizons of the two species have not yet been made clear (CHEN, 1956; CHEN and Sheng, 1957).

The Maok'ou Limestone in the midstream area of the Yangtze river and its southwestern area overlies the Chihsia Limestone and consists of the NeoschwagerinaVerbeekina and the Yabeina zone (CHEN and Sheng, 1957). These two zones are apparently equivalent to those of the upper subformation of the Kozaki formation. 
Dunbar and Misch (1947) described Schubertella giraudi, Staffella sp., Cancellina schellwieni, C. cf. primigena, and Nankinella cf. orbicularia from two localities of the geosynclinal belt near Chienchuan, north of Tali, Yunnan. The specimen described under the name of $C$. cf. primigena is apparently a primitive species of Neoschwagerina and is probably referable to $N$. simplex. The rocks containing these species are undoubtedly assigned to the $N$. simplex zone.

\section{Pamir and Darwas}

Doutkevitch and Khabakov (1934) described $N$. cf. simplex, C. primigena, Misellina termieri pamirensis, M. cf. parvicostata, Verbeekina sp., and Schubertella giraudi from Kuberganda of Eastern Pamir. Of these the first is identical with $N$. sphaerica (M.-MACLAY) from Crimea, which in turn could be a geographical variant of $N$. simplex. The species of Misellina and Cancellina are not identical with $M$. claudiae and $C$. tenuitesta of the Kozaki formation, but are similar in their evolutionary stage. Thus this fauna is referable to the $N$. simplex zone. In addition, Yangchienia compressa, Pseudofusulina bactriana karasuensis and P. cf. kraffti have been identified from Kara-su of the same area. The latter two species may belong to one and the same species and are closely allied to $P$. (Skinnerella) gruperaensis. This fauna recalls that of the Misellina claudiae zone in Japan.

Kalymykova (1960) divided the Permian of Darwas into several zones, none of which, however, is referable to the $N$. simplex zone with precision. The $\mathrm{V}$ zone of the lower Kubergandynskyy "horizon" carries the following species: Misellina termieri (DePrat), M. parvicostata (DePrat), Brevaxina dyrenfurthi (DoutKevitch), Nan-kinella orbicularia (LEE), Schubertella giraudi (DEPRAT), Triticites contractus (ScHeLLwien), T. ordinatus Chen, Pseudofusulina furoni Thompson, P. exigua (Schellwien), $P$. vulgaris (Schellwien), and Schwagerina neolata Thompson. This fauna includes the species known from various horizons ranging from the middle part of the Pseudoschwagerina zone to the Polydiexodina zone. It is uncertain to me whether this fauna represents strictly one definite zone or is a composite of more than two zones. However, general specific constitution seems to indicate that this zone is older than the $M$. claudiae zone of the Kozaki formation. The occurrence of small forms of Misellina, and $T$. contractus and $T$. ordinatus which are considered as early representatives of Nagatoella strongly supports warrantableness of this correlation.

The VI zone of the upper Kubergandynskyy horizon contains $M$. claudiae, $M$. parvicostata, $M$. termieri, and $B$. dyrenfurthi. Except $M$. claudiae this zone has no comparable species with those of the Kozaki formation, but judging from the faunal succession above and below it is highly probable that this zone is referable to the $M$. claudiae zone of the Kozaki formation.

The VII zone, the Murgabskyy "horizon", contains $M$. sp. and Polydiexodina darvasica Doutkevitch. No true Polydiexodina has been known in Japan, but in the Bamian Limestone of Afghanistan P. afghanensis occurs in association with more advanced species of the Neoschwagerininae and Sumatrininae than those of the $N$. simplex zone, such as $N$. craticulifera haydeni and Afghanella schencki (Thompson, 1946). This fact suggests that the VII zone is younger than the $N$. simplex zone.

\section{Crimea}

In Crimea many species of the Neoschwagerininae and Sumatrininae have been described, of which $N$. sphaerica (M. -MACLAY) is closely allied to $N$. simplex in its 
important characteristics. The two species could be considered as representing mere geographical variants. MACLAY's Cancellina primigena also appears to be conspecific with $N$. sphaerica, as far as is seen in its figures. Praesumatrina primitiva and $P$. cf. schellwieni may probably be identical with each other and are closely allied to C. tenuitesta of the Kozaki formation. The precise stratigraphic distribution of these species has not been confirmed, but they are possibly of the same stratigraphic zone as the $N$. simplex zone.

\section{Yugoslavia}

KochansKy-Devidé (1958) discriminated three assemblages of fusuline species in the limestone blocks of the Carnian conglomerate in southern Crna Gora of Montenegro. One of them, which was considered by him to indicate the oldest horizon in the original stratigraphic sequence, comprises, among others, Yangchienia antiqua, Misellina aliciae, Pseudodoliolina ozawai, Neoschwagerina bukowskii, N. schuberti, and $N$. craticulifera. Of these the last three species are most characteristic. Kochansky correlated the fauna with those of the $\mathrm{Nn}$ zone of Akasaka, the Chihsia Limestone and Bajar-Dar of eastern Pamir.

$N$. schuberti is closely allied to $N$. simplex in its specific characters and its evolutionary stage. $N$. bukowskii is the most primitive form of Cancellina of the group of $C$. primigena or $C$. neoschwagerinoides. It closely resembles $C$. tenuitesta. The species identified with $N$. craticulifera is not typical but undoubtedly a smaller subspecific form of the species. Yangchienia antiqua is most closely allied to $Y$. compressa among the known species of the genus.

Thus the $N$. bukowskii zone is confidently correlated with the $N$. simplex zone of the Kozaki formation.

\section{Mexico and Guatemala}

It is interesting to find some similar or identical species of the Schwagerininae with those of southern Mexico and Guatemala in the M. claudiae and $N$. simplex zones of the Kozaki formation. For instance, Parafusulina (Skinnerella) gruperaensis, which was originally described from the Grupera formation of Chiapas (Thompson and Miller, 1944) and later identified by KLING (1960) from the Chochal formation of the Chiantla area, Guatemala, is identical with ours. The Kozaki specimens assigned to this species occur in the Misellina claudiae zone just below the $N$. simplex zone. In the Chochal formation of Chiantla this species is associated with Eoverbeekina americana Thompson and Miller (KLING, 1960).

Another example is Parafusulina (Skinnerella) sapperi (Staff). Although the exact stratigraphic position of STAFF's specimens is uncertain. Dunbar(1939) assigned this species, together with $P$. guatemalaensis, to the Leonardian (possibly the Wordian). These species show close similarities in general stage of evolution with the species of Parafusulina described by KLING (1960) from the Chochal and the Paseo Hondo formation. $P$. sapperi is very close to $P$. edoensis of the $P$. kaerimizensis zone in the Akiyoshi and Atetsu Limestones. In the Kozaki formation $P$. ( $S$. ) sapperi is associated with Neoschwagerina simplex, Verbeekina sphaera, Cancellina tenuitesta, etc.

The third identical species is Schwagerina figueroai Thompson and Mrler from the La Vainilla Limestone of Chiapas. It occurs from the $M$. claudiae zone of the Kozaki formation. It shows a close resemblane in general features to $S$. similucera granda Nogam from the upper part of the Pseudofusulina kraffti magna zone in the 
Atetsu Limestone.

Although neither neoschwagerines nor verbeekinines available for more precise correlation have been known, the presence of some identical species and the general similarity in the evolutionary stage of the large species of Schwagerina and Parafusulina demonstrate the approximate contemporaneity of the $N$. simplex zone of the Kozaki formation to the upper part of the La Vainilla formation and the Paseo Hondo formation at Chiapas and to the Chochal formation at Chiantla in its lower part and to the Chochal at Purulhá in its upper part. The faunal connection of East Asia to Central America in this stage is also indicated by the occurrence of Eoverbeekina which is one of the diagnostic elements of the Chihsia Limestone.

KLING (1960) assigned the Chochal Limestone of Chiantla to the Wolfcampian and Leonardian ages and that of Purulhá to the Leonardian and early Guadalupian ages. The Permian Subcommittee of the National Research Council's committee on stratigraphy of U. S. A. in 1960 (Chairman, C. O. DunBAR) correlated the La Vainilla formation with the upper Wolfcampian and the Paseo Hondo formation with the Leonardian. On carefully comparing the species of Parafusulina of the Leonardian Hess member of Glass Mountain, Texas, with the central American species of the Schwagerininae, Ross (1960, p. 122) reached the same conclusion for the correlation of those formations.

Adopting these opinions and taking the occurrence and association of the related species into consideration I am of the opinion that the Misellina claudiae zone can be correlated with the Lower Leonardian and the Neoschwagerina simplex zone with the Upper Leonardian*.

Many species of Parafusulina have been described from various parts of Japan, and most of them are restricted to the upper part of the Pseudofusulina ambigua zone, that is, the Misellina claudiae zone, and the Parafusulina kaerimizensis zone, namely the Neoschwagerina simplex zone. Ross (1960) compared the species of Parafusulina from various provinces of Eastern Hemisphere with those of the Hess member as being of approximately the same age on the basis of their close similarities in general stage of evolution. He also suggested that Verbeekina, Neoschwagerina, and Pseudodoliolina have stratigraphic ranges reaching well down into strata equivalent to the Leonardian. His opinion is confirmed by the association of such primitive species as mentioned in page 118 of Neoschwagerina, Cancellina, Verbeekina, and Pseudodoliolina with some identical or closely related species of Parafusulina to those of Central America. As mentioned in page 110, a few species of Misellina appear in older strata, that is, the Pseudofusulina vulgaris zone of the upper part of the Pseudoschwagerina zone, which is approximately correlated with the Upper Wolfcampian.

\section{Sikhote-Alin}

It has been known that a thick series of the Carboniferous and Permian sediments is distributed in the southern borderland area of Manchuria, China, carries fusulines with a Millerella or Eostaffella (Minato, 1950), a Pseudoschwagerina (ToRIyama and Minato. 1943) and a Yabeina-Lepidolina fauna (NodA, 1951). This geosynclinal belt is extended northward into the Sikhote-Alin range. In the Primorye area Sosmina $(1952,1960)$ distinguished, besides the Carboniferous and Lower Permian

* I (1957) once referred the N. simplex zone to the Lower Guadalupian, but the correlation should be revised. 
foraminiferal faunas, a fusuline fauna containing Cancellina primigena, Misellina claudiae, $M$. ex. gr. claudiae, and Pseudofusulina kraffti (YeliseYeva and SosNina, 1952; Yeliseyeva, 1959; Sosnina, 1960).

Yeliseyeva (1959) indicated that the Sibaygousskaya formation of the OlgaTetyukhinsk area contains Cancellina ex. gr. primigena, Neoschwagerina inflata Sosnina and $N$. ussurica Sosnina. This formation is underlain conformably by the Zarodovskaya formation carrying Misellina cf. claudiae and further down by the Kavalerovskaya formation containing Pseudofusulina ex. gr. vulgaris, Acervoschwagerina sp. and others, and is overlain unconformably by the Chuandalazkaya formation with Reichelina sp. aff. rhomboidea Sosnina. This Lower and Middle Permian faunal sequence is nearly parallel to that of the Japanese Islands, and the Cancellina-Neoschwagerina fauna is represented by the species of the same group as those of the $N$. simplex zone of the Kozaki formation.

\section{Concluding remarks}

It has been clarified by authors that in Middle and Upper Permian time the genera of the Neoschwagerininae, Sumatrininae, and Verbeekininae are wide-spread in a relatively narrow belt extending from the Mediterranean region across the Middle East and southern and eastern Asia to the West-coast area of North America and Central America and also to northeastern Australia. Correlation among these areas has hitherto been made at the generic level in terms of the zone of NeoschwagerinaVerbeekina and the zone of Yabeina. Further works are required for accomplishing more accurate zonation and correlation at the specific level.

As I have mentioned in the preceding article, however, we can recognize the close similarities of the species and the assemblage of species of the Misellina claudiae and the Neoschwagerina simplex zone with those of each of the corresponding zones in distant regions from the standpoint of world-wide correlation. Most of the species of the $N$. simplex zone which is best displayed in the Akasaka Limestone and the Kozaki formation have a relatively short stratigraphic range, and the assemblage of those species can indicate a definite geological age. Some of the species of the zone are practically useful as zonal indices for the interregional as well as local correlation in early neoschwagerininen age.

Regarding the closely allied species among the regions under consideration a further detailed palaeontological study is necessary on their extent of variation and their accurate stratigraphic positions and ranges. There is a possibility, as I have indicated in the preceding article, that some of such species would be either of mere geographical variants or a subspecific distinction. For example, Neoschwagerina shaerica and Cancellina primigena by M. -MACLAY (1957) from Crimea and C. cf. primigena by DuNBAR and Misch (1947) from southern Yunnan are probably identical with $N$. simplex. Praesumatrina primitiva and $P$. cf. schellwieni described by M. -MACLAY (1957) from Crimea are nothing but variants within one and the same species, which is probably of subspecific differentiation from Cancellina tenuitesta of the Kozaki formation. Identity is also considered probably between Parafusulina sapperi from Central America and Japan and $P$. multiseptata from south China. Yangchienia compressa in Japan, $Y$. iniqua in South China, and Y. antiqua in Montenegro may possibly be regarded as a subspecific separation from one another, if their variation is statistically examined on sufficient materials.

There are of course certain species which seem to be endemic to each region 
under consideration. The available data are, however, still insufficient to know whether they are truely endemic or wide-spread. A good example that seems to be endemic according to our present knowledge is the species of Nagatoella which are known only in Japan. However certain species that are regarded as predecessors of Nagatoella occur in South China and Pamir as mentioned in pages 92 and 126. This suggests that Nagatoella could be recognized to be more wide-spread in the future.

Despite the occurrence of the three identical species between the $N$. simplex zone of Japan and the corresponding zone of Guatemala no correlative fauna has been confirmed in the west coast region of North America. This may be due to incomplete collecting. An interesting record which suggests the existence of a comparable fauna is an assemblage of Neoschwagerina sp., Schwagerina sp., and Yangchienia n. sp. (?) which were listed by Aitken (1959, p. 31) from Hall Lake in the Atlin map area, British Columbia.

The apparent difference in the assemblage of species among the corresponding zones may be due to either insufficient collecting or to ecological and sedimentary conditions. A remarkable example is recognized between the faunules of Akiyoshi and Akasaka as already indicated by NogAmi (1961). The available evidence has proved that the Parafusulina kaerimizensis zonule of the Akiyoshi and the Atetsu Limestone is contemporaneous with the Neoschwagerina simplex zonule of the Akasaka Limestone. No significant difference in facies and lithology of the limestone of these three areas can be recognized. $N$. simplex, Cancellina nipponica, and C. tenuitesta have not been found from the former two, while there is no record of the occurrence of Parafusulina kaerimizensis from the latter one, although further collecting may be necessary. On the other hand the $N$. simplex zonule of the Kozaki formation carries the combined faunules of both Akiyoshi and Akasaka, but it shows the remarkable difference in facies and lithology from those of the latter two. The reason for this fact may be explained from local palaeogeographical distribution rather than ecological and sedimentary conditions, but still remains to be studied from various points of view.

\section{References cited}

Akasaka research group (Morikawa, R., Okubo, M., Murata, M., Sato, T., Igo, H., and Taguchi, K.) (1956): Geological Studies of the Akasaka Limestone. Chikyu-Kagaku (Earth Science), (26-27), 10-18.

Chen, S. (1934): Fusulinidae of South China, Part I, Palaeontologia Sinica, [B], 4, (2), 1-185, pl. $1-16$.

- (1956): Fusulinidae of South China, Part II. Ibid., [B], (6), 17-69, pl. 1-16.

CHEN, S. and SHENG, J.C. (1957): Stratigraphic distribution and correlation of the index fusuline species of the Carboniferous and Permian in China (in Chinese). Abstract on fundamental problems in Chinese Geology. 1-12.

Coogan, A. H. (1960): Stratigraphy and Paleontology of the Permian Nosoni and Dekkas formations (Bollibokka Group). Univ. of California publications in geological sciences, 36, (5), 243-316, pl. 22-27.

Deprat, J. (1912): Ktude des Fusulinidés de Chine et d'Indochine et classification des calcaires à fusulines. Mém. Indochine Service Géol., 1, (3), 1-76, pl. 1-9.

(1913): Etude des Fusulinidés du Japon, de Chine et d'Indochine et classification des calcaires à fusulines (III ${ }^{e}$ Mém.). Etude comparative des Fusulinidés d'Akasaka (Japon) et des Fusulinidés de Chine et d'Indochine. Ibid., 3, (1), 1-45, pl. 1-8.

Doutkevitch, G. A. and Khabakov, A.B. (1934): Permian fauna of Fusulinidae found in Sections 
of Kara-Su and Kuberganda in East Pamir. Acad. Sci., U.S.S.R., Tadjik complex Exped., 1932, Geol. Pamir, 8, 53-104, pl. 1-3.

Dunbar, C. O. (1939): Permian fusulines from Central America. Jour. Paleont., 13, (3), 344-348, pl. 35,36 .

(chairman) (1960): Correlation of the Permian formations of North America. Bull. Geol. Soc. America, 71, 1763-1806, 1 pl.

Dunbar, C. O. and Skinner, J. W. (1937): The Geology of Texas, 3, (2), Permian Fusulinidae of Texas. Univ. Texas, Bull. 3701, 517-826, pl. 42-81.

Dunbar, C. O. and Misch, P. (1947): Fusuline-bearing Permian rocks of northwestern Yunnan. Bull. Geol. Soc. China, 27, 101-110, 1 pl.

Fujit, K., Kanmema, K., and Matsumoto, T. (1962): Notes on the Chichibu geosyncline. Appendix to FujII, K. (1962): Petrography of the Upper Palaeozoic sandstones from the Yatsushiro area, Kyushu. Mem. Fac. Sci., Kyushu Univ., [D], 12, (3), 204-216.

Fusimoto, H. (Huziмoтo, H.) (1936): Stratigraphical and palaeontological studies of the Titibu System of the Kwanto-mountainland. Part 2, Palaeontology. Sci. Rep. Tokyo Bunrika Daigaku, [C], (2), 32-125, pl. 1-26.

- (1956): A new species of Parafusulina from the Kitakami massif, Japan. Trans. Proc. Paleont. Soc. Japan, [N. S.]. (21), 157-160, pl. 25.

- (1959): Recent studies on the Palaeozoic rocks of Japan (in Japanese). Jour. Geol. Soc. Japan. 65, (766), 406-411 (English translation: Intern. Geol. Review, 3, (11), 975-981).

Fujimoto, H. and Kanuma, M. (1953): Minojapanella, a new genus of Permian fusulinids. Jour. Paleont., 27, (1), pl. 19.

Fujimoto, H. , Kanuma, H., and Igo, H. (1962): Upper Paleozoic formations of the Hida massif. Geologic Research of the Hida Massif, 44-70.

Hayden, H. H. (1909): Fusulinidae from Afghanistan. India Geol. Survey Records, 38, 230-256, pl. 17-22.

Hanzawa, S. (1950): On the occurrence of forminiferal genera, Eoverbeekina, Nankinella and Sphaerulina from Japan. Short papers of Inst. Geol. Paleont. Tohoku Univ., (2), 1-12, 2 pls.

Honso, S. (1959): Neoschwagerinids from the Akasaka Limestone. Jour. Fac. Sci., Hokkaido Univ. , [IV], 10, (1), 111-161, pl. 1-12.

Iao, H. and Ogawa, K. (1958): Fusulinids from the Funafuseyama Limestone, Part I. Jubilee Publication in the Commemoration of Prof. H. Fujimoto, 49-54, pls. 1, 2.

Isomi, H. and Kuroda, K. (1958): Geology of the western part of Wakasa district, Fukui Prefecture. Monthly Rep. Geol. Survey Japan, 9, (3), 133-143.

Kalmykova, M. A. (1960): Zonalnoe raschlenenie Verkhnego Paleozoya Darvaza po Fusulynydam. Vsesoyuznyy Nauchno-Isskdovaklskyy Geol. Inst. (Vsegei), Informatsionny Sbornik, (35), 39-49.

Kanmera, K. (1956): Toriyamaia, a Permian fusulinid genus from the Kuma massif, Kyushu, Japan. Trans. Proc. Palaeont. Soc. Japan, [N.S.], (24), 241-257, 1 pl.

(1957): Revised classification of Cancellina and Neoschwagerina, and evolution of Sumatrininae and Neoschwagerininae. Mem. Fac. Sci., Kyushu Univ., [D], 6, (1), 47-64, pls. 19,20 .

(1961): Middle Permian Kozaki formation (in Japanese with English abstract). Sci. Rep., Fac. Sci., Kyushu Univ., Geol. 5, (4), 196-215.

KanUMA, M. (1958-60): Stratigraphical and palaeontological studies of the southern part of the Hida Plateau and the northeastern part of the Mino Mountainland. Part 1, Stratigraphy. Jubilee Publication in the Commemoration of Prof. H. Fusimoto, 1-48; Part II, no. 3, Bull. Tokyo Gakugei Univ., 10, 59-83, pl. 4-9 (1959); Part II, no. 4, ditto, 11, 55-73, pl. 10-13 (1960).

Kling, S. A. (1960): Permian fusulinid from Guatemala. Jour. Paleont., 34, (4), 637-655, pl. 78-82.

Коваудант, M. (1956): On some new species of Rauserella from Mt. Ibuki, Shiga Prefecture, Central Japan. Trans. Proc. Paleont. Soc. Japan, [N.S.], (23), 225-228, pl. 32.

(1957): Paleontological study of the Ibukiyama Limestone, Shiga Prefecture, Central 
Japan. Sci. Rep. Tokyo Kyoiku Daigaku, [C], (48), 247-311, pl. 1-10.

KochangKy-DevidÉ, V. (1958): Die Neoschwagerininenfaunen der Südlichen Crna Gora (Montenegro), Geolôski Vjesnik Szezak, (9), 45-76, pl. 1-6.

LANGE, E. (1925): Eine Mittelpermische Fauna von Guguk Bulat (Padanger Oberland, Sumatra), Konikl. Nederlands Geol. -Mijnb. Genootschap Verh., Geol. Ser., (7), 213-295, pl. 1-5.

LEE, J. S. (1931): Distribution of the dominant types of the fusulinid forminifera in the Chinese Seas. Geol. Soc. China, Bull., 10, 273-290.

(1933): Taxonomic criteria of Fusulinidae with notes on seven new Permian genera. Mem. Nat. Research Inst. Geol., (14), 1-21, pl. 1-5.

Mrkudrho-MaCLAY, A. D. (1955): New data on Permian fusulinids of the southeastern part of USSR. Acad. Nauk USSR, Doklady, [N.S.] 105, (3), 573-576.

(1957): Nekotory Fusulinidy Permi Krima. Seriya Geol. Nauk, 9 (225), 93-159, pl. 1-14.

Miklukho-Maclay, A. D., Rauser-Chernousova, D. M., and Pozovskaya, C. E. (1959): Otryad Fusulinida in Osnovi Paleontologii, Akademii Nauk SSSR, 201-215, pl. 6-11.

Minato, M., Hashimoto, S., Suyama, K., Takeda, H., Suzuki, T., Kimura, S., Yamada, K., Kakimi, T., IChiKaWA, T., and Suyetomi, H. (1954): Zur Biostratigraphie der permischen Formation des Setamai-Geländes im Süd-Kitakami Gebirge. Jour. Geol. Soc. Japan, 60, (708), 378-387.

MorikaWa, R. (1958): Fusulinids from the Akasaka Limestone (part 1). Sci. Rep. Saitama Univ., [B], 3, (1), 93-127, pl. 12-26.

- (1960): Fusulinids from the Iwaizaki Limestone. Ibid. 3, (3), 273-297, pl. 46-53.

Morikawa, R. and Isomi, H. (1961): Studies of Permian fusulinids in the east of Lake Biwa, central Japan. Geol. Survey of Japan, Rep. (191), 1-30, pls. 1-21.

Morikawa, R. and Horiguchi, M. (1956): Parafusulina nakamigawai, n. sp. from the Adoyama formation in the neighbourhood of Kuzu city, Tochigi Prefecture. Sci. Rep. Saitama Univ., [B], 2, (2), 261-264, pl. 35.

Nogami, Y. (1961): Permische Fusuliniden aus dem Atetsu-Plateau sudwestjapans. Teil 1, Fusulininae und Schwagerininae. Mem. Coll. Sci., Univ. Kyoto, [B], 27, (3), 159-225, pl. 1-11; Teil 2, Verbeekininae, Neoschwagerininae u. a., Ibid., 28, (2), 159-228, pl. 1-7.

ONUKi, Y. (1956): Geology of the Kitakami massif. Explanatory text of the geological map of the Irvaté Prefecture., 1-189.

Onuki, Y., Murata, M., Bando, Y., and Mito, A. (1960): On the Permian System of the Maiya district in the Southern Kitakami massif, Japan. Jour. Geol. Soc. Japan, 66, (782), 717-732.

Ozawa, Y. (1925): Palaeontological and stratigraphical studies on the Permo-Carbonifeorus Limestone of Nagato, Part II, Palaeontology. Jour. Coll. Sci., Imp. Univ. Tokyo, 45, (6), 1-90, pl. 1-14.

- (1927): Stratigraphical studies of the Fusulina Limestone of Akasaka, Province of Mino. Jour. Fac. Sci., Imp. Univ. Tokyo, [II], 2, (3), 121-164, pl. 34-45.

Rauser-Chernousova, D. (1935): On the Lower-Permian age of the sediments with Pseudofusulina lutugini (Soheldwien) on the western slope of Ural. Soc. Naturalistes, Moscou, Bull. sect. Geol., 13, (1), 129-154, pl. 1, 2.

Ross, C. A. (1960): Fusulinids from the Hess members of the Leonard formation, Leonard series (Permian), Glass Mountains, Texas. Contr. Cushman Found. Foramin. Research, 10, (4), 117-133, pl. 17-21.

Sheng, J. C. (1956): Permian fusulinids from Liangshan, Hanchung, Southern Shensi. Acta Palacontologia Sinica, 4, (2), 157-228, pl. 1-8.

(1958): Some fusulinids from the Maok'ou Limestone of Chinghai province, northwestern China. Ibid., 6, (3), 268-291, pl. 1-4.

Sosnina, M. I. (1956): Materialy po Paleontologyy. Novye cemeystva i rody. Trudy Vsyegyei, [N. S. $], 12,15-29$, pls. 1-7.

(1960): Microfaunistic zone in the Carboniferous and Permian deposits of the SikhoteAlin. Mezhdunarodnyy Geologichesky Kongress, XXI sessiya, Doklady Sovyetskikh Geologov, $65-68,1 \mathrm{pl}$.

Staff, H. von (1912): Monographie der Fusulinen, Teil III, Die fusulinen (Schellwienien) Nord- 
amerikas. Paleontographica, 59, 157-191, pls. 15-20.

Sugi, T. (1960): Restudy of Vebeekina sphaera Ozawa. Trans. Proc. Paleont. Soc. Japan. [N.S.], 39, 311-320, pl. 36 .

SUyari, K. (1954): Geology of the vicinity of Kamodani, Tokushima Prefecture. Part 1, Jour. Gakugei Tokushima Univ., Nat. Sci., 5, 94-101.

- (1962): Geological and paleontological studies in central and eastern Shikoku, Japan. Part II, Paleontology, Ibid., 12, 1-64, pl. 1-12.

Thompson, M. L. (1935): The fusulinid genus Yangchienia Lee. Eclogae Geologicae Helvetiae, 28, 511-517, 1 pl.

(1936 a): Nagatoella, a new genus of Permian fusulinids. Trans. Paleont. Soc. Japan, 7, 195-202, pl. 12.

(1936 b): The fusulinid genus Verbeekina. Jour. Paleont., 10, (3), 193-201, 1 pl.

- (1937): Fusulinids of the Subfamily Schubertellinae. Ibid., 11, (2), 118-125, 1 pl.

(1946): Permian fusulinids from Afghanistan. Ibid., 20, (2), 140-157, pl. 23-26.

(1948): Studies of American fusulinids. Univ. Kansas, Paleont. Contr. Protozoa, 1, 1-102, pl. 1-38.

Thompson, M. L. and Mrllek, A. K. (1944): The Permian of southernmost Mexico and its fusulinid genus. Jour. Paleont., 18, (6), 481-504, pl. 74-84.

Toriyama, R. (1952): Permian fusulinids from the Kitakami mountainland, northeast Japan. Mem. Fac. Sci., Kyushu Univ., [D], 3, (3), 127-155, pl. 3-7.

_- (1954): Geology of Akiyoshi, Part 1, Study of the Akiyoshi Limestone group. Ibid., 4, (1), 39-97.

- (1957): Geology of the Akiyoshi Limestone Plateau. The Board of Education of Yamaguchi Prefecture, 1-36.

- (1958): Geology of Akiyoshi, Part III, Fusulinids of Akiyoshi. Mem. Fac. Sci., Kyushu Univ. , [D], 7, 1-264, pl. 1-48.

Yeliseyeva, V. K. (1959): Osnovnyye cherty stratigrafii i paleogeografii Kamennougolnykh i Permskikh otlozheny Sikhote-Alinya. Sovetskaya Geologiya, 5, 45-65. (Translation by Research International; Intern. Geol. Review, 1, (12), 1-20, 1959).

Yeliseyeva, V. K. and Sosnina, M. I. (1952): Novyye dannye po Verkhney Permi Khrebta Sikhote-Alin. Akademiya Nauk SSSR, Doklady, Seriya Geologicheskaya, 32, (6) 
Table 1. Measurements of Sphaerulina crassispira

\begin{tabular}{|c|c|c|c|c|c|c|c|c|c|c|}
\hline \multirow{2}{*}{ Specimen } & \multirow{2}{*}{$\mid \begin{array}{c}\text { Number } \\
\text { Vol. }\end{array}$} & \multirow{2}{*}{ Length } & \multirow{2}{*}{ Width } & \multirow{2}{*}{$\begin{array}{l}\text { Form } \\
\text { ratio }\end{array}$} & \multirow{2}{*}{$\begin{array}{l}\text { Diam. } \\
\text { Prol. }\end{array}$} & \multicolumn{5}{|c|}{ Height of } \\
\hline & & & & & & 1 & 2 & 3 & 4 & 5 \\
\hline GKD12206 & $9 x / 2$ & 2.21 & 2.62 & .84 & \multirow{2}{*}{$\mid \begin{array}{c}.115(?) \\
-\end{array}$} & $.060(?)$ & .080 & .088 & .096 & .112 \\
\hline " 12212 & $8 \pi / 2$ & 2.01 & 2.25 & .89 & & $.054(?)$ & \multirow[b]{2}{*}{$\begin{array}{l}.004 \\
.064\end{array}$} & .080 & .096 & .112 \\
\hline " 12213 & $91 / 4$ & $1.97(+)$ & 2. 46 & .80 & .112 & .064 & & .080 & .096 & .096 \\
\hline 12216 & 8 & 1.72 & 2.05 & .84 & $.88^{*}$ & .064 & .072 & \multirow{2}{*}{$\begin{array}{l}.096 \\
.080\end{array}$} & .104 & .128 \\
\hline 12219 & 8 & $1.56(+)$ & 1.84 & .84 & \multirow{3}{*}{$\begin{array}{l}.144 \\
.096 \sim \\
.112 \\
.112\end{array}$} & $.064(?)$ & .080 & & .096 & .112 \\
\hline " 12385 & 8 & - & 1.76 & - & & .060 & .080 & .076 & .093 & .104 \\
\hline " $12271, \mathrm{~b}$ & $51 / 2$ & - & 1.07 & - & & .064 & .075 & .088 & .088 & \multirow{2}{*}{$\begin{array}{l}.096 \\
.112\end{array}$} \\
\hline " $12165, \mathrm{~b}$ & 7 & - & 1.64 & - & - & - & .064 & .080 & .096 & \\
\hline 12169 & 9 & - & $2.50(t)$ & - & - & $.064(?)$ & \multicolumn{3}{|c|}{$.064(?) .064(?) .096$} & .096 \\
\hline " 12202 & 8 & - & 1.88 & - & .128 & .064 & .080 & .096 & .096 & .112 \\
\hline$c_{n}$ & & & & Thick & of $\mathrm{s}$ & theca & & & & \\
\hline Specimen & 1 & 2 & 3 & 4 & 5 & 6 & 7 & & 8 & 9 \\
\hline GKD12206 & .012 & - & .024 & .024 & - & .041 & .041 & & .049 & .055 \\
\hline " 12212 & - & - & .024 & - & .029 & - & .038 & & .047 & - \\
\hline " 12213 & - & .012 & $.016(?)$ & ) .020 & .027 & .031 & .037 & & .039 & .045 \\
\hline " 12216 & .010 & - & $.020(?)$ & .020 & .024 & .031 & .028 & & .033 & $.036(?)$ \\
\hline 12219 & .010 & - & .024 & .024 & - & - & .032 & & .036 & - \\
\hline " 12385 & .012 & .014 & .020 & .020 & .024 & .026 & .029 & & .045 & - \\
\hline " $12271, \mathrm{~b}$ & - & .016 & .018 & .018 & - & - & - & & - & - \\
\hline " $12165, \mathrm{~b}$ & - & - & - & - & .029 & .034 & .040 & & - & - \\
\hline " 12169 & - & - & - & - & - & .031 & .036 & & .041 & .053 \\
\hline " 12202 & - & - & - & - & .029 & - & .036 & & .042 & - \\
\hline
\end{tabular}

* not well-centered

Table 2. Measurements of Nagatoella

\begin{tabular}{|c|c|c|c|c|c|c|c|c|c|c|c|c|}
\hline \multirow{2}{*}{ Specimen } & \multirow{2}{*}{$\begin{array}{c}\text { Number } \\
\text { Vol. }\end{array}$} & \multirow{2}{*}{ Length } & \multirow{2}{*}{ Width } & \multirow{2}{*}{\multicolumn{2}{|c|}{$\begin{array}{l}\text { Form } \\
\text { ratio }\end{array}$}} & \multirow{2}{*}{$\begin{array}{l}\text { Diam } \\
\text { Prol. }\end{array}$} & \multicolumn{6}{|c|}{ Height of } \\
\hline & & & & & & & & 2 & 3 & & 4 & 5 \\
\hline \multirow{4}{*}{$\begin{array}{ll}\text { GKD12096, a } \\
\text { " } 12096, \mathrm{~b} \\
\text { " } 12445 \\
\text { " } 12091\end{array}$} & $71 / 2$ & 3. 08 & 3.08 & \multirow{4}{*}{\multicolumn{2}{|c|}{$\begin{array}{r}1.23 \\
-\overline{8} \\
1.86 \\
-\end{array}$}} & \multirow{4}{*}{$\mid \begin{array}{c}.160 \\
.080 \sim .112 \\
.096 \sim .128 \\
.096 \sim .112\end{array}$} & & .032 & .045 & \multirow{2}{*}{\multicolumn{2}{|c|}{$\begin{array}{l}.056 \\
.072\end{array}$}} & .076 \\
\hline & 7 & \multicolumn{2}{|c|}{ (deformed) } & & & & & $24 \quad .040$ & .048 & & & .088 \\
\hline & 9 & 3.73 & 2.00 & & & & & $32 \quad .036$ & .056 & .0 & & .085 \\
\hline & 9 & - & 1.40 & & & & & .032 & .040 & .0 & 56 & .076 \\
\hline \multirow{2}{*}{ Specimen } & \multicolumn{8}{|c|}{ Thickness of spirotheca } & \multicolumn{4}{|c|}{ Tunnel angle } \\
\hline & 1 & 2 & 3 & 4 & 5 & 6 & 7 & $\overline{8}$ & 1 & 2 & 3 & $\overline{4}$ \\
\hline \multirow{4}{*}{$\begin{array}{ll}\text { GKD12096, a } \\
\text { " } 12096, \mathrm{~b} \\
\text { " } 12445 \\
\text { " } 12091\end{array}$} & .008 & .012 & - & - & .020 & .025 & .041 & - & 20 & \multirow{2}{*}{\multicolumn{3}{|c|}{$\begin{array}{l}19 \quad 30 \quad 33 \\
\text { (deformed) }\end{array}$}} \\
\hline & .008 & .008 & .010 & - & .016 & .024 & .036 & - & & & & \\
\hline & .014 & .016 & .016 & 019 & .024 & .035 & .048 & .040 & 30 & - & 32 & 30 \\
\hline & .006 & .008 & .010 & .011 & .018 & .025 & .038 & - & - & - & - & - \\
\hline
\end{tabular}


japonica sp. nov., in millimeters

\begin{tabular}{|c|c|c|c|c|c|c|c|c|c|c|c|c|}
\hline \multicolumn{5}{|c|}{ volutions } & \multicolumn{8}{|c|}{ Form ratio of volutions } \\
\hline 6 & 7 & 8 & 9 & 10 & 1 & 2 & 3 & 4 & 5 & 6 & 7 & 8 \\
\hline .128 & .144 & .168 & .194 & $.194(?)$ & .50 & .59 & .62 & .70 & .76 & .87 & .85 & .83 \\
\hline .128 & .152 & .194 & - & - & - & .50 & .62 & .62 & .72 & .78 & .89 & .86 \\
\hline .128 & .144 & .176 & .160 & - & .50 & .61 & .75 & .76 & .84 & .85 & .85 & .88 \\
\hline .136 & .160 & .160 & - & - & .57 & .63 & .70 & .71 & .78 & .80 & .80 & - \\
\hline .128 & .148 & .144 & - & - & .50 & .66 & .75 & $.85(?)$ & .84 & .87 & .80 & - \\
\hline .104 & .144 & $.144(?)$ & - & - & - & - & - & - & - & - & - & - \\
\hline- & - & - & - & - & - & - & - & - & - & - & - & - \\
\hline .144 & .176 & - & - & - & - & - & - & - & - & - & - & - \\
\hline .128 & .160 & .160 & .194 & - & - & - & - & - & - & - & - & - \\
\hline .128 & .160 & $.194(?)$ & - & - & 一 & - & - & - & - & - & - & 一 \\
\hline \multicolumn{11}{|c|}{ Septal Count } & \multirow{2}{*}{ Pl. } & \multirow{2}{*}{ Fig. } \\
\hline 1 & 2 & \multicolumn{2}{|l|}{3} & 4 & 5 & \multicolumn{2}{|r|}{6} & 7 & \multicolumn{2}{|c|}{8} & & \\
\hline - & - & \multicolumn{2}{|l|}{ - } & - & - & \multicolumn{2}{|c|}{-} & - & \multicolumn{2}{|c|}{-} & 12 & 14 \\
\hline- & - & \multicolumn{2}{|l|}{-} & - & - & \multicolumn{2}{|c|}{ - } & - & \multicolumn{2}{|c|}{ - } & 12 & 15 \\
\hline- & - & \multicolumn{2}{|l|}{-} & - & - & \multicolumn{2}{|c|}{-} & 一 & \multicolumn{2}{|c|}{-} & 12 & 13 \\
\hline - & 一 & \multicolumn{2}{|l|}{-} & - & - & & 一 & 一 & \multicolumn{2}{|c|}{-} & - & - \\
\hline- & - & \multicolumn{2}{|l|}{-} & - & - & & - & - & \multicolumn{2}{|c|}{-} & - & - \\
\hline 8 & 11 & \multicolumn{2}{|l|}{15} & 16 & 17 & & 20 & 21 & \multicolumn{2}{|c|}{-} & 19 & 10 \\
\hline 8 & 13 & \multicolumn{2}{|l|}{16} & 18 & 21 & & - & - & \multicolumn{2}{|c|}{-} & 12 & 25 \\
\hline- & $1 \dot{3}$ & 14 & & 15 & 17 & & 20 & - & - & & 12 & 24 \\
\hline- & - & 14 & & 18 & 20 & & 22 & 20 & 1 & & 12 & 22 \\
\hline - & - & - & & $19(?)$ & 20 & & 21 & - & - & & 12 & 23 \\
\hline
\end{tabular}

sp., in millimeters

\begin{tabular}{|c|c|c|c|c|c|c|c|c|c|c|c|c|}
\hline \multicolumn{4}{|c|}{ volutions } & \multicolumn{9}{|c|}{ Form ratio of volutions } \\
\hline 6 & 7 & 8 & 9 & 1 & & & 3 & 4 & 5 & 6 & 7 & 8 \\
\hline .096 & .128 & $.144(?)$ & - & 2.25 & & & 2.22 & 2.40 & 2.41 & 2.43 & 2.25 & - \\
\hline .112 & - & - & 一 & - & & - & - & - & - & - & - & - \\
\hline .112 & .144 & .176 & .194 & 1.5 & & & 2.0 & 2.0 & 2.1 & 2.1 & 1.9 & 1.8 \\
\hline .101 & .144 & .176 & - & - & & & - & - & - & - & - & - \\
\hline \multicolumn{3}{|c|}{ (degrees) } & \multicolumn{8}{|c|}{ Septal count } & \multirow{2}{*}{ Pl. } & \multirow{2}{*}{ Fig. } \\
\hline 5 & 6 & 7 & 1 & 2 & 3 & 4 & 5 & 6 & 7 & 3 & & \\
\hline \multirow[t]{2}{*}{38} & 46 & 44 & - & - & - & - & - & - & - & - & 14 & 23 \\
\hline & & & - & - & - & - & - & - & - & - & 14 & 22 \\
\hline 36 & 35 & 34 & - & - & - & - & - & - & - & - & 19 & 13 \\
\hline- & - & - & 8 & 11 & 13 & 13 & 14 & 18 & 20 & 21 & 14 & 24 \\
\hline
\end{tabular}


Table 3. Measurements of Parafusulina (Skinnerella)

\begin{tabular}{|c|c|c|c|c|c|c|c|c|c|c|c|c|c|c|}
\hline \multirow{2}{*}{\multicolumn{2}{|c|}{ Spe }} & \multirow{2}{*}{$\begin{array}{c}\text { Number } \\
\text { vol. }\end{array}$} & \multirow{2}{*}{\multicolumn{2}{|c|}{ Length }} & \multirow{2}{*}{ Width } & \multirow{2}{*}{$\begin{array}{l}\text { Form } \\
\text { ratio }\end{array}$} & \multirow{2}{*}{\multicolumn{2}{|c|}{$\begin{array}{l}\text { Diam. } \\
\text { Prol. }\end{array}$}} & \multicolumn{6}{|c|}{ Height of } \\
\hline & & & & & & & & & \multicolumn{2}{|c|}{1} & 2 & \multicolumn{2}{|l|}{3} & 4 \\
\hline \multicolumn{2}{|c|}{ GKD12252 } & $6 x / 2$ & \multicolumn{2}{|c|}{8.06} & 3.26 & \multicolumn{2}{|c|}{2.47} & $.325 \sim .345$ & \multicolumn{2}{|c|}{.100} & .186 & \multicolumn{2}{|c|}{.229} & .257 \\
\hline & 12250 & $5 x / 2$ & \multicolumn{2}{|c|}{5.57} & 2.88 & \multicolumn{2}{|c|}{1.92} & $.384 \sim .450$ & \multicolumn{2}{|c|}{.129} & .186 & \multicolumn{2}{|c|}{.222} & .300 \\
\hline "I & 12280 & $6 x / 2$ & \multicolumn{2}{|c|}{$7.07^{*}$} & 3.30 & \multicolumn{2}{|c|}{ 2. 14} & .346 & \multicolumn{2}{|c|}{.100} & .143 & \multicolumn{2}{|c|}{.186} & .229 \\
\hline$" \prime$ & 12253 & 6 & \multicolumn{2}{|r|}{ - } & 2.92 & \multicolumn{2}{|c|}{ - } & $.346 \sim .374$ & \multicolumn{2}{|c|}{.114} & .153 & \multicolumn{2}{|c|}{.193} & .300 \\
\hline$" \prime$ & 12247 & $61 / 4$ & & - & 3.41 & - & 3 & $\sim .355$ & 1 & & .172 & .27 & & .286 \\
\hline "I & 12244 & $51 / 4$ & & - & 2.76 & - & & $\sim .365$ & .1 & & .186 & .24 & & .329 \\
\hline & & & orm & atio & of volu & utions & & & & hht & $\mathrm{fc}$ & cions & & \\
\hline & & 1 & 2 & 3 & 4 & 5 & 6 & 1 & 2 & 3 & 4 & 5 & 6 & 7 \\
\hline & $\mathrm{D} 12252$ & 2.00 & 2.10 & 2.11 & 2.25 & 2.27 & 2.27 & .030 & .046 & .057 & .060 & .075 & .086 & .086 \\
\hline " & 12250 & 2.00 & .10 & 2.16 & 2.04 & 2.06 & 一 & .043 & .043 & .057 & .086 & .086 & - & 一 \\
\hline "I & 12280 & 1. 99 & . 10 & 2.13 & 2.10 & 2.14 & 2.20 & .036 & .043 & .043 & .064 & .086 & .086 & - \\
\hline "I & 12253 & - & - & - & - & - & - & .029 & .036 & .050 & .064 & .079 & .086 & - \\
\hline "I & 12247 & - & - & - & - & - & 一 & .036 & .043 & .057 & .072 & .086 & .093 & - \\
\hline 11 & 12244 & - & - & - & - & - & - & .036 & .043 & .050 & .057 & .072 & - & - \\
\hline
\end{tabular}

* two times of the half length

Table 4. Measurements of Parafusulina (Skinnerella)

\begin{tabular}{|c|c|c|c|c|c|c|c|c|c|c|c|c|}
\hline \multirow{2}{*}{\multicolumn{2}{|c|}{ Specimen }} & \multirow{2}{*}{$\begin{array}{c}\text { Number } \\
\text { vol. }\end{array}$} & \multirow{2}{*}{ Length } & \multirow{2}{*}{ Width } & \multirow{2}{*}{$\begin{array}{l}\text { Form } \\
\text { ratio }\end{array}$} & \multirow{2}{*}{$\begin{array}{l}\text { Diam. } \\
\text { Prol. }\end{array}$} & \multicolumn{6}{|c|}{ Height of } \\
\hline & & & & & & & 1 & & 2 & & 3 & 4 \\
\hline \multicolumn{2}{|c|}{ GKD12182 } & 7 & 12. $3(+)$ & 4. $40(+)$ & 2.8 & .533 & .164 & & .197 & & .250 & .348 \\
\hline & 12177 & $53 / 4$ & 9.63 & 3.65 & 2.64 & $.369^{*}$ & .128 & & .185 & & .210 & .290 \\
\hline " & 12183 & 6 & 9.88 & 3. 79 & 2.60 & .615 & .205 & & .220 & & .287 & .290 \\
\hline " & 12174 & $71 / 4$ & - & 3.57 & - & .410 & .144 & & .158 & & .185 & .246 \\
\hline " & 12180 & 7 & - & 3. 81 & - & .395 & .184 & & .205 & & .246 & .328 \\
\hline " & 12175 & $6 x / 2$ & 一 & 3. 69 & - & .410 & .123 & & .205 & & .255 & .295 \\
\hline \multirow{2}{*}{\multicolumn{2}{|c|}{ Specimen }} & \multicolumn{8}{|c|}{ Thickness of spirotheca } & \multicolumn{3}{|c|}{ Tunnel angle } \\
\hline & & 1 & 2 & 3 & 4 & 5 & 6 & 7 & & 1 & 2 & 3 \\
\hline \multicolumn{2}{|c|}{ GKD12182 } & .040 & .045 & .051 & .064 & .080 & .112 & - & & 20 & 27 & 28 \\
\hline$" \prime$ & 12177 & .035 & .048 & .053 & .064 & .076 & .106 & 一 & & 25 & 21 & 29 \\
\hline "I & 12183 & $.048(?)$ & .060 & .064 & .080 & .080 & - & 一 & & 26 & 20 & 28 \\
\hline " & 12174 & .040 & .048 & .064 & .072 & .068 & .100 & .096 & & - & - & - \\
\hline " & 12180 & .040 & .045 & .055 & .080 & .087 & .112 & .083 & & 一 & - & - \\
\hline " & 12175 & .035 & .043 & .048 & .064 & .080 & .080 & - & & - & - & - \\
\hline
\end{tabular}


gruperaensis THомpson and MLLLER, in millimeters

\begin{tabular}{|c|c|c|c|c|c|c|c|c|c|c|c|c|c|}
\hline \multicolumn{5}{|c|}{ volutions } & \multicolumn{9}{|c|}{ Radius Vector } \\
\hline \multicolumn{2}{|c|}{5} & 6 & 7 & & 1 & \multicolumn{2}{|c|}{2} & 3 & 4 & 5 & \multicolumn{2}{|r|}{6} & 7 \\
\hline \multicolumn{2}{|c|}{.272} & .300 & .315 & & .269 & \multicolumn{2}{|c|}{.461} & .691 & .941 & 1. 21 & \multicolumn{2}{|c|}{ 1. 498} & - \\
\hline \multicolumn{2}{|c|}{.322} & - & - & & .326 & & & .730 & 1.037 & 1. 34 & \multicolumn{2}{|c|}{1.536} & - \\
\hline \multicolumn{2}{|c|}{.300} & .286 & - & & .269 & & & .595 & .826 & 1.11 & \multicolumn{2}{|c|}{ 1. 382} & - \\
\hline & & .329 & 一 & & .307 & & & .710 & .998 & 1.30 & \multicolumn{2}{|c|}{$1.593(?)$} & $1.612(?)$ \\
\hline & & $.355(?)$ & 一 & & .307 & & & .768 & 1.037 & 1. 34 & \multicolumn{2}{|c|}{$1.685(?)$} & - \\
\hline & & - & 一 & & .288 & & & .720 & 1.056 & 1. 34 & \multicolumn{2}{|r|}{ - } & - \\
\hline \multicolumn{6}{|c|}{ Tunnel angle (degrees) } & \multicolumn{5}{|c|}{ Septal counts } & \multirow{2}{*}{\multicolumn{2}{|c|}{ Pl. }} & \multirow{2}{*}{ Fig. } \\
\hline 1 & 2 & 3 & 4 & 5 & 6 & 1 & 2 & 3 & 4 & 5 & & & \\
\hline 26 & 27 & 23 & 27 & 29 & 29 & - & 一 & - & - & - & - & 15 & 11 \\
\hline 27 & 28 & 33 & 29 & 27 & - & - & - & - & - & - & - & 15 & 10 \\
\hline 31 & 23 & 26 & 22 & 21 & 31 & - & 一 & - & - & - & - & 15 & 9 \\
\hline- & - & - & - & - & - & 10 & 18 & 23 & 27 & 35 & $37(?)$ & 15 & 13 \\
\hline- & - & - & - & - & - & 9 & 16 & 21 & 29 & 35 & - & 15 & 12 \\
\hline- & - & - & - & - & - & 9 & 16 & 21 & 31 & 33 & - & - & - \\
\hline
\end{tabular}

figueroai ThOMPson and MILLER, in millimeters

\begin{tabular}{|c|c|c|c|c|c|c|c|c|c|c|}
\hline \multicolumn{4}{|c|}{ volutions } & \multicolumn{7}{|c|}{ Form ratio of volutions } \\
\hline 5 & \multicolumn{2}{|c|}{6} & 7 & 1 & 2 & \multicolumn{2}{|c|}{3} & 4 & 5 & 9 \\
\hline .38 & \multicolumn{2}{|c|}{.410} & - & 1.70 & 1.72 & \multicolumn{2}{|c|}{2.14} & 2.59 & 2.70 & 2.76 \\
\hline .38 & \multicolumn{2}{|c|}{.500} & - & 1.66 & 2.00 & \multicolumn{2}{|c|}{2.45} & 2.40 & 2.50 & - \\
\hline .36 & \multicolumn{2}{|c|}{ - } & - & 1.75 & 1.84 & \multicolumn{2}{|c|}{2.31} & 2.48 & 2.60 & 2.60 \\
\hline $.2 \varepsilon$ & \multicolumn{2}{|c|}{.328} & .287 & - & - & \multicolumn{2}{|c|}{-} & 一 & - & - \\
\hline .37 & \multicolumn{2}{|c|}{.410} & .287 & - & - & \multicolumn{2}{|c|}{ - } & - & - & 一 \\
\hline .4 & \multicolumn{2}{|c|}{.470} & - & - & - & \multicolumn{2}{|c|}{-} & - & - & - \\
\hline \multicolumn{2}{|c|}{ (degrees) } & \multicolumn{7}{|c|}{ Septal count } & D1 & \\
\hline 4 & 5 & 1 & 2 & 3 & 4 & 5 & 6 & 7 & 51. & Fig. \\
\hline 29 & 32 & - & - & - & - & - & - & - & 16 & 1 \\
\hline 30 & - & - & - & - & - & - & - & - & 16 & 3 \\
\hline 32 & - & - & 一 & - & - & - & 一 & - & 16 & 2 \\
\hline- & - & 11 & 23 & 24 & 28 & 31 & 35 & 40 & - & - \\
\hline- & 一 & 9 & 19 & 23 & 27 & 28 & 30 & - & 16 & 5 \\
\hline- & - & 10 & 21 & 29 & 36 & 37 & 41 & - & - & - \\
\hline
\end{tabular}


Table 5. Measurements of Parafusulina nakamigawai

\begin{tabular}{|c|c|c|c|c|c|c|c|c|c|c|}
\hline \multirow{2}{*}{ Specimen } & \multirow{2}{*}{$\begin{array}{c}\text { Number } \\
\text { vol. }\end{array}$} & \multirow{2}{*}{ Length } & \multirow{2}{*}{ Width } & \multirow{2}{*}{$\begin{array}{l}\text { Form } \\
\text { ratio }\end{array}$} & \multirow{2}{*}{$\begin{array}{l}\text { Diam. } \\
\text { Prol. }\end{array}$} & \multicolumn{5}{|c|}{ Height of } \\
\hline & & & & & & 1 & 2 & & & 4 \\
\hline GKD12429 & $6 \pi / 2$ & 14.70 & 3. 46 & 4.2 & $.27 *$ & .125 & .173 & .2 & & .275 \\
\hline " 12436 & 6 & 12.00 & 3. 42 & 3.5 & $.31^{*}$ & .144 & .162 & .2 & & .300 \\
\hline " 12402 & $6 \pi / 2$ & 13. 40 & 3.61 & 3.7 & $.31^{*}$ & .115 & .160 & .3 & & .326 \\
\hline " 12416 & $61 / 4$ & 14.98 & 3.73 & 4.0 & .37 & .115 & .154 & .2 & & .305 \\
\hline " 12434 & $6 \pi / 2$ & 15.00 & 3. 57(?) & 4.2 & $.29 *$ & .108 & .154 & .2 & & .307 \\
\hline " 12418 & 6 & - & 3.65 & - & .42 & .134 & .211 & .2 & & .326 \\
\hline " 12428 & 6 & - & 3.50 & - & .36 & .115 & .154 & .2 & & .269 \\
\hline " 12413 & $5 \pi / 2$ & - & 3. 34 & - & .38 & .134 & .192 & .2 & & .307 \\
\hline " 12411 & 6 & - & 3.46 & - & .35 & .115 & .192 & .2 & & .320 \\
\hline \multirow{2}{*}{ Specimen } & \multicolumn{7}{|c|}{ Thickness of spirotheca } & \multicolumn{3}{|r|}{ Septal } \\
\hline & 1 & 2 & & 3 & 4 & 5 & 6 & 1 & 2 & 3 \\
\hline GKD12429 & .029 & .031 & .04 & & .057 & .079 & .090 & - & - & - \\
\hline " 12436 & .038 & .031 & .04 & & .057 & .086 & .086 & - & - & - \\
\hline " 12402 & .029 & .036 & .04 & & .070 & .086 & .092 & - & - & - \\
\hline " 12416 & .029 & .031 & .04 & & .060 & .075 & .092 & - & - & - \\
\hline " 12434 & - & .031 & .04 & & .057 & .079 & .086 & - & - & - \\
\hline " 12418 & .033 & .038 & .04 & & .067 & .092 & .092 & 11 & 23 & 29 \\
\hline " 12428 & .029 & .029 & .04 & & .057 & .081 & .072 & 12 & 29 & 32 \\
\hline " 12413 & .031 & .036 & .0 & & .072 & .086 & .086 & 13 & 28 & 34 \\
\hline " 12411 & .029 & .029 & .0 & & .057 & .072 & .086 & 14 & 27 & 32 \\
\hline
\end{tabular}


Morikawa and HoRIguchi, in millimeters

\begin{tabular}{|c|c|c|c|c|c|c|c|c|}
\hline \multicolumn{2}{|c|}{ volutions } & \multicolumn{5}{|c|}{ Form ratio of volutions } & \multirow{2}{*}{$\mathrm{Pl}$. } & \multirow{2}{*}{ Fig. } \\
\hline 5 & 6 & 1 & 2 & 3 & 4 & 5 & & \\
\hline .394 & .307 & 3.0 & 3.4 & 3.6 & 4.2 & 4.4 & - & - \\
\hline .422 & .374 & 2.5 & 2.5 & 2.9 & 3.2 & 3.5 & - & - \\
\hline .441 & .307 & 3.3 & 3.8 & 4.0 & 4.0 & 4.0 & 18 & 2 \\
\hline .384 & .403 & 2.4 & 2.7 & 2.8 & 3.6 & 3.9 & 18 & 1 \\
\hline .346 & $.307(?)$ & - & 2.3 & 2.9 & 3.7 & 4.1 & - & - \\
\hline .384 & .326 & - & - & - & - & - & 18 & 3 \\
\hline .422 & .346 & - & - & - & - & - & 18 & 4 \\
\hline .415 & - & - & - & - & - & - & - & - \\
\hline .410 & .384 & - & - & - & - & - & - & - \\
\hline \multicolumn{3}{|l|}{ count } & \multicolumn{6}{|c|}{ Tunnel angle (degrees) } \\
\hline 4 & 5 & 6 & 1 & 2 & 3 & 4 & 5 & 6 \\
\hline - & - & - & - & 25 & 29 & 36 & 40 & 43 \\
\hline- & - & - & 22 & 26 & 21 & 34 & 44 & - \\
\hline - & - & - & - & - & 27 & 29 & 44 & - \\
\hline- & - & - & 20 & 23 & 27 & 28 & 31 & 27 \\
\hline- & - & - & - & 19 & 34 & 29 & 35 & - \\
\hline 32 & 35 & $35(?)$ & - & - & - & - & - & - \\
\hline 33 & 41 & - & - & - & - & - & - & - \\
\hline 41 & 40 & - & - & - & - & - & - & - \\
\hline 40 & 41 & $48(?)$ & - & - & - & - & - & - \\
\hline
\end{tabular}


Table 6. Measurements of Parafusulina (Parafusulina)

\begin{tabular}{|c|c|c|c|c|c|c|c|c|c|}
\hline \multirow{2}{*}{ Specimen } & \multirow{2}{*}{$\begin{array}{c}\text { Number } \\
\text { vol. }\end{array}$} & \multirow{2}{*}{ Length } & \multirow{2}{*}{ Width } & \multirow{2}{*}{$\begin{array}{l}\text { Form } \\
\text { ratio }\end{array}$} & \multirow{2}{*}{$\begin{array}{l}\text { Diam. } \\
\text { Prol. }\end{array}$} & \multicolumn{4}{|c|}{ Height of } \\
\hline & & & & & & 1 & 2 & 3 & 4 \\
\hline GKD12051 & 8 & $17.0 *$ & 4.70 & 4.75 & $.329 \sim .389$ & .112 & .136 & .128 & .168 \\
\hline " 12029 & 7 & $11.97 *$ & - & - & .369 & .080 & .104 & .138 & .176 \\
\hline " 12025 & 7 & $13.7 *$ & 2.99 & 4.56 & .322 & .096 & .120 & .176 & .194 \\
\hline " 12004 & 7 & 14.0 & $2.80(6 \mathrm{r} / 2 \mathrm{v})$. & - & $.326 \sim .384$ & .105 & .115 & .173 & .211 \\
\hline " 12045 & 7 & - & 3.28 & - & .430 & .100 & .136 & .160 & .218 \\
\hline " 12002 & $6 \pi / 2$ & - & 2.99 & - & $\mid .287 \sim .329$ & .064 & .112 & .168 & .242 \\
\hline \multirow{2}{*}{ Specimen } & \multicolumn{9}{|c|}{ Thickness of spirotheca } \\
\hline & 1 & & 3 & 4 & 5 & 6 & & 7 & 8 \\
\hline GKD12051 & .037 & .0 & .048 & .052 & .056 & .096 & & .080 & .080 \\
\hline " 12029 & .024 & .0 & .048 & .048 & .064 & .072 & & - & - \\
\hline " 12025 & .032 & .0 & .040 & .052 & .069 & .069 & & - & - \\
\hline "I 12004 & .029 & .0 & .045 & .055 & .072 & .079 & & - & - \\
\hline " 12045 & .040 & .0 & .043 & .064 & .096 & .096 & & .080 & - \\
\hline " 12002 & .024 & .0 & .043 & .075 & .088 & - & & - & - \\
\hline
\end{tabular}

* outer volutions exfoliated or deformed

Table 7. Measurements of Verbeekina sphaera Ozawa,

\begin{tabular}{|c|c|c|c|c|c|c|c|c|c|c|c|c|}
\hline \multirow{2}{*}{ Specimen } & \multirow{2}{*}{$\begin{array}{c}\text { Number } \\
\text { vol. }\end{array}$} & \multirow{2}{*}{ Length } & \multirow{2}{*}{ Width } & \multirow{2}{*}{$\begin{array}{l}\text { Form } \\
\text { ratio }\end{array}$} & \multirow{2}{*}{\multicolumn{2}{|c|}{$\begin{array}{l}\text { Diam. } \\
\text { Prol. }\end{array}$}} & \multicolumn{6}{|c|}{ Height of } \\
\hline & & & & & & & 1 & 2 & 3 & 4 & 5 & 6 \\
\hline GKD12067 & $10^{x / 2}$ & 3. $81 *$ & 4. $0^{*}$ & 1.0 & & - & .048 & .056 & .072 & .124 & .152 & .210 \\
\hline " 12052 & $11 \frac{1}{2}$ & 4. 10 & 3.44 & 1.18 & & 055 & .048 & .048 & .064 & .096 & .128 & .160 \\
\hline " 12015 & $6 \pi / 2$ & 2. 42 & 2.17 & 1.1 & & 050 & .040 & .064 & .080 & .112 & .160 & .194 \\
\hline 12127 & 11 & 4. 14 & 3. 61 & 1.11 & & - & .044 & .048 & .072 & .120 & .146 & .194 \\
\hline " 12084 & 11 & 4. 39 & 3. 93 & 1.11 & & - & - & .050 & .064 & .100 & .152 & .194 \\
\hline \multirow{2}{*}{ Specimen } & \multicolumn{10}{|c|}{ Thickness of spirotheca } & \multirow{2}{*}{ P1. } & \multirow{2}{*}{ Fig } \\
\hline & 1 & 2 & 4 & 5 & 6 & 7 & 8 & 9 & 10 & 11 & & \\
\hline GKD12067 & .010 & $.016 \quad .020$ & 0.025 & .029 & .033 & .033 & .042 & .033 & .045 & - & 15 & 3 \\
\hline " 12052 & .010 & .012 .020 & 0.025 & .029 & .033 & .036 & .036 & .041 & .045 & .053 & 15 & 2 \\
\hline " 12015 & .013 & $.012 \quad .022$ & 2.027 & .033 & .036 & .042 & - & - & - & - & - & - \\
\hline 12127 & .010 & .019 & - & .036 & .036 & .048 & .056 & .064 & .064 & .056 & 15 & 4 \\
\hline " 12084 & - & $.016 \quad .025$ & - & .033 & .040 & .035 & .048 & .056 & .064 & .088 & 15 & 1 \\
\hline
\end{tabular}

* Measured at the 10 th volution 
kaerimizensis OzAWA, in millimeters

\begin{tabular}{|c|c|c|c|c|c|c|c|c|c|c|}
\hline \multicolumn{4}{|c|}{ volutions } & \multicolumn{7}{|c|}{ Form ratio of volutions } \\
\hline 5 & 6 & 7 & 8 & 1 & 2 & 3 & 4 & 5 & 6 & 7 \\
\hline .210 & .242 & .282 & .274 & 2.0 & 2.6 & 2. & 2.9 & 3.1 & 3.5 & 4.0 \\
\hline .226 & .242 & - & 一 & 2.1 & 2.7 & 2. & 3.1 & 3.6 & 4.1 & - \\
\hline .210 & .242 & $.290(?)$ & - & 2.5 & 3.0 & 3. & 3. 2 & 3.6 & 4.0 & - \\
\hline $.250(?)$ & $.307(?)$ & - & - & \multicolumn{7}{|c|}{ (diagonal section) } \\
\hline .290 & .290 & .315 & - & - & - & - & - & - & - & - \\
\hline .290 & .290 & - & - & - & - & - & - & - & - & - \\
\hline \multicolumn{8}{|c|}{ Septal count } & \multirow{2}{*}{\multicolumn{2}{|c|}{ P1. }} & \multirow{2}{*}{ Fig. } \\
\hline 1 & 2 & 3 & 4 & 5 & \multicolumn{2}{|c|}{6} & 7 & & & \\
\hline- & - & - & 一 & - & \multicolumn{2}{|c|}{-} & - & \multicolumn{2}{|c|}{18} & 6 \\
\hline - & - & - & - & - & \multicolumn{2}{|c|}{ - } & - & \multicolumn{2}{|c|}{16} & 7 \\
\hline - & - & - & - & - & \multicolumn{2}{|c|}{-} & - & \multicolumn{2}{|c|}{17} & 5 \\
\hline- & - & - & - & - & \multicolumn{2}{|c|}{-} & - & \multicolumn{2}{|c|}{16} & 6 \\
\hline 10 & 19 & 22 & 25 & 28 & 2 & & 29 & \multicolumn{2}{|c|}{18} & 8 \\
\hline 10 & 18 & 24 & 27 & 28 & \multicolumn{2}{|c|}{$33(?)$} & - & \multicolumn{3}{|c|}{-} \\
\hline
\end{tabular}

in millimeters

\begin{tabular}{|c|c|c|c|c|c|c|c|c|c|c|c|c|c|c|}
\hline \multicolumn{5}{|c|}{ volutions } & \multicolumn{10}{|c|}{ Form ratio of volutions } \\
\hline 7 & 8 & 9 & 10 & 11 & 1 & 2 & 3 & 4 & 5 & 6 & 7 & 8 & 9 & 10 \\
\hline .244 & .258 & .266 & .250 & - & .50 & .71 & .81 & .90 & .93 & .95 & 1.0 & 1.0 & 1.0 & - \\
\hline .196 & .200 & .210 & .258 & .258 & 一 & .90 & .90 & .97 & .95 & 1.0 & 1.0 & 1.0 & 1.04 & 1.09 \\
\hline .226 & - & - & - & - & .75 & .85 & .93 & .97 & 1.0 & 1.06 & 1.1 & - & - & - \\
\hline .226 & .242 & .242 & .258 & .218 & - & 1.0 & 1.0 & .94 & 1.0 & 1.05 & 1.0 & 1.0 & 1.05 & 1.09 \\
\hline .210 & .224 & .274 & .242 & .258 & - & 1.0 & 1.0 & 1.16 & 1.20 & 1.13 & 1.15 & 1.15 & 1.15 & 1.15 \\
\hline
\end{tabular}


Kametoshi KANMERA

Fusulines of the Middle Permian Kozaki Formation

of Southern Kyushu

\section{Plates 11-19}


Plate 11 


\section{Explanation of Plate 11}

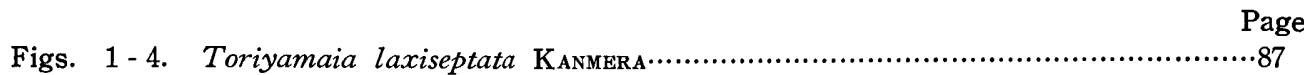

1. Diagonal section (paratype), GKD 10202; 2, axial section (holotype, immature), GKD 10201; 3, sagittal section (paratype), GKD 10211; 4, tangential section (paratype), GKD 10203.

All figures x 25. loc. $\mathrm{Km} 5209(=\mathrm{Kz} 209, \mathrm{~b}$ member $)$ at Uminoura, Tanoura-mura, Kumamoto Prefecture

Figs. 5-13. Yangchienia compressa (OzAWA)

5. Axial section, GKD 12095; 6, tangential section, GKD 12308, b; 7, tangential section GKD 12102; 8, diagonal section, GKD 12112; 9, parallel section, GKD 12326; 10, diagonal section, GKD 12321; 11, oblique section, GKD 12114, b; 12, enlarged figure of the same specimen as fig. 5 .

$5-7,9,10, \times 10 ; 8,11,12, \times 25$

5 (=12)-8, 11 from loc. $\mathrm{Km} 7574$ (f member) in Mameguri-dani, Sakamoto-mura; 9, 10 from loc. $\mathrm{Km} 5216$ (probably d member) at Uminoura, Tanoura-mura, Kumamoto Prefecture

13, Oblique section of a syntype from the $\mathrm{Nn}$ zone of the Akasaka Limestone (OzaWA, 1927), illustrating an example of this species that has the chomata as thick as in the Kozaki specimens.

Figs. 14-21. Nankinella kozakiensis sp. nov. (See also Plate 12)

14, Axial section of the holotype, GKD 12151, a; 15, 16, axial sections of paratypes, GKD 12155, a, 12143; 17, axial section of a paratype (immature) GKD 12144, a; 18, tangential section of a paratype, GKD 12152; 19, sagittal section of a paratype, GKD 12146, a; 20, 21, parallel sections of paratypes, GKD 12157, 12160.

$16,19, \times 25$; others x ca. 26, polished specimen. All from loc. $\mathrm{Km}$ $5004, \mathrm{~h}$ (b member) in Kozaki-dani, Sakamoto-mura.

Photos by $\mathrm{K}_{\text {ANMERA }}$ 

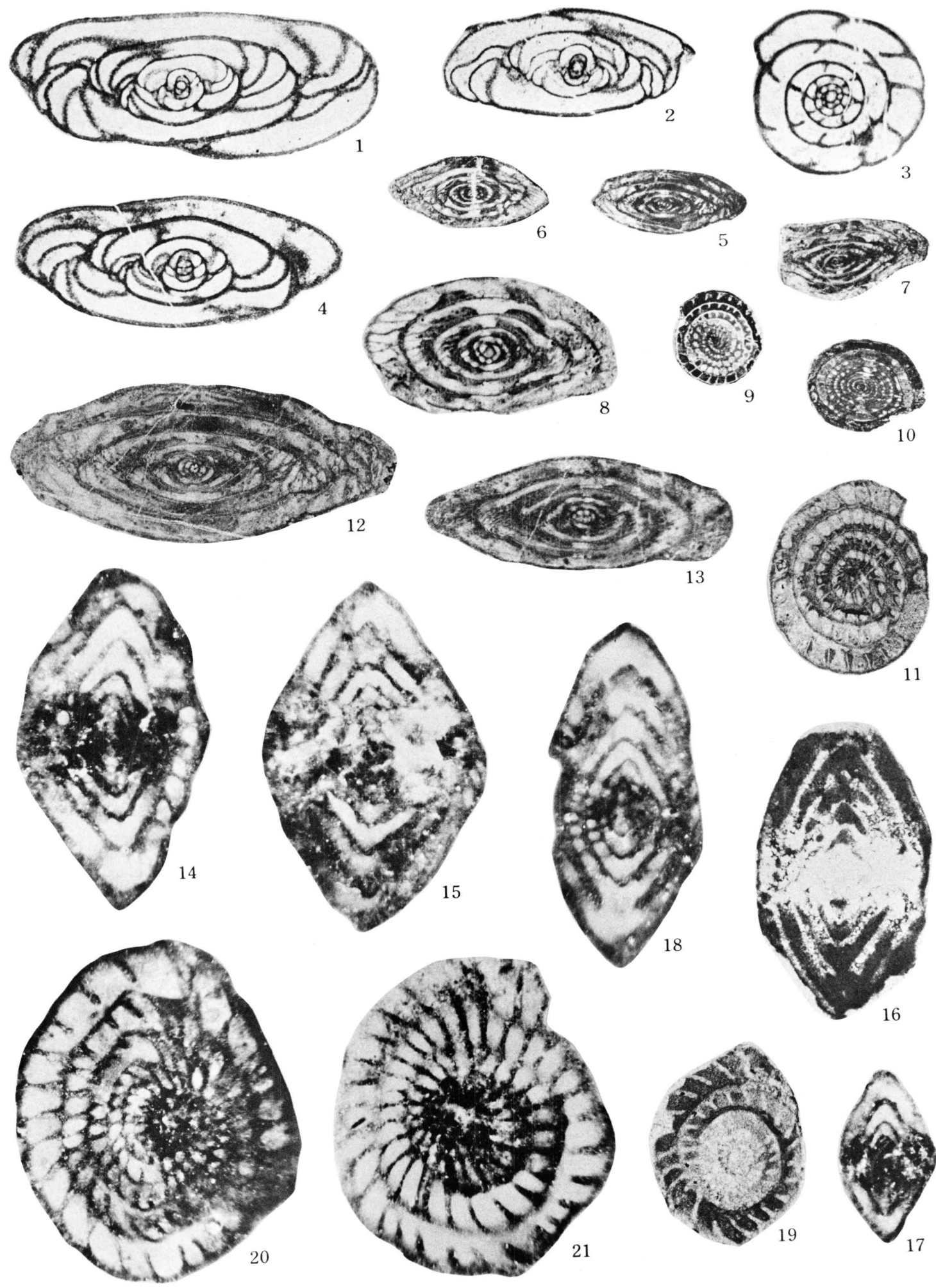

K. Kanmera: Fusulines of the Kozaki Formation 
Plate 12 


\section{Explanation of Plate 12}

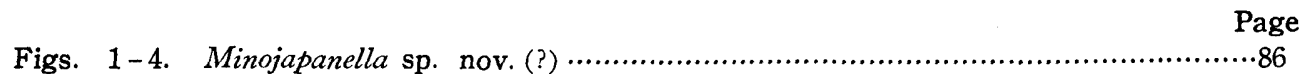

1. Diagonal section of an immature specimen, GKD 12415;2, oblique section, GKD 12426; 3, 4, parallel sections, GKD 12403, 12401.

All x 25; loc. $\mathrm{Km} 5209$ (b member), Uminoura, Tanoura-mura.

Figs. 5-7. Nankinella kozakiensis sp. nov. (See also Plate 11) …........................81

5. Axial section of a paratype (immature) GKD 12142; 6, the same specimen as fig. 16 of Plate 11 (GKD 12143); 7. slightly diagonal sagittal section of a paratype, GKD 12137.

5 , x 25; 6, 7, x 10 . All from loc. $\mathrm{Km} 5004, \mathrm{~h}$ (b member) in Kozakidani, Sakamoto-mura.

Figs. 8-12. Schubertella giraudi (DEPRAT)

8. Slightly diagonal axial section, GKD 12032; 9, tangential section, GKD 12145; 10, diagonal section, GKD 12146, b; 11, 12, parallel sections, GKD 12146, c, 12147.

8 from loc. $\mathrm{Km} 1696$ (f member); 9-12 from loc. $\mathrm{Km} \mathrm{5004,} \mathrm{h} \mathrm{(b}$ member), both in Kozaki-dani, Sakamoto-mura.

Figs. 13-29. Sphaerulina crassispira japonica subsp. nov.

13. Axial section of a paratype, GKD 12213, 14, axial section of the holotype, GKD 12306; 15, 16, slightly diagonal axial sections of paratypes, GKD 12212, 12209, a; 17, 18, 19, axial sections of paratypes, GKD 12261, 12144, b, 12165, a; 20, 21, tangential sections of paratypes, GKD 12167, 12271, a; 22, 23, 24, 25, sagittal sections of paratypes, GKD 12169, 12202, 12165, b, 12271, b; 26, slightly diagonal axial section of a paratype, GKD 12209, b; 27, axial section of a paratype, GKD 12168; 28, 29, enlarged figures of a part of the holotype (GKD 12306) and the same specimen as fig. 13 (GKD 12213), showing the structure of the spirotheca.

$13-27, \times 10 ; 28,29, \times 100 ; 13-17,23,26$ from loc. $\mathrm{Km} \mathrm{7584,} \mathrm{b} \mathrm{(b}$ member), 21, 25 from loc. $\mathrm{Km} 7584$ (b, member), both in Éri-dani; $18-20,22,24,27$, from loc. $\mathrm{Km} 5004, j$, in Kozaki-dani, Sakamotomura.

Photos by Kanmera 

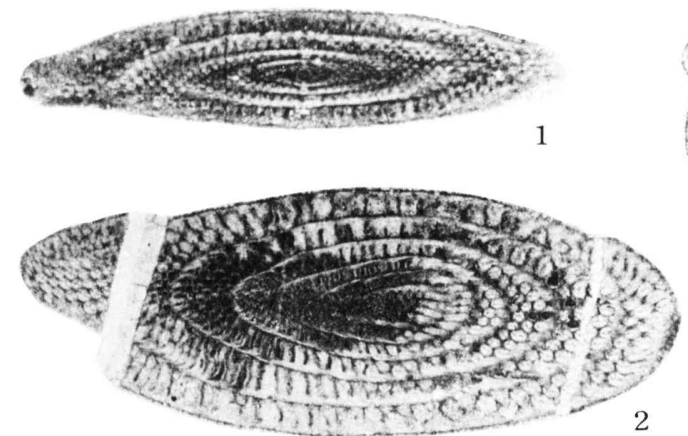
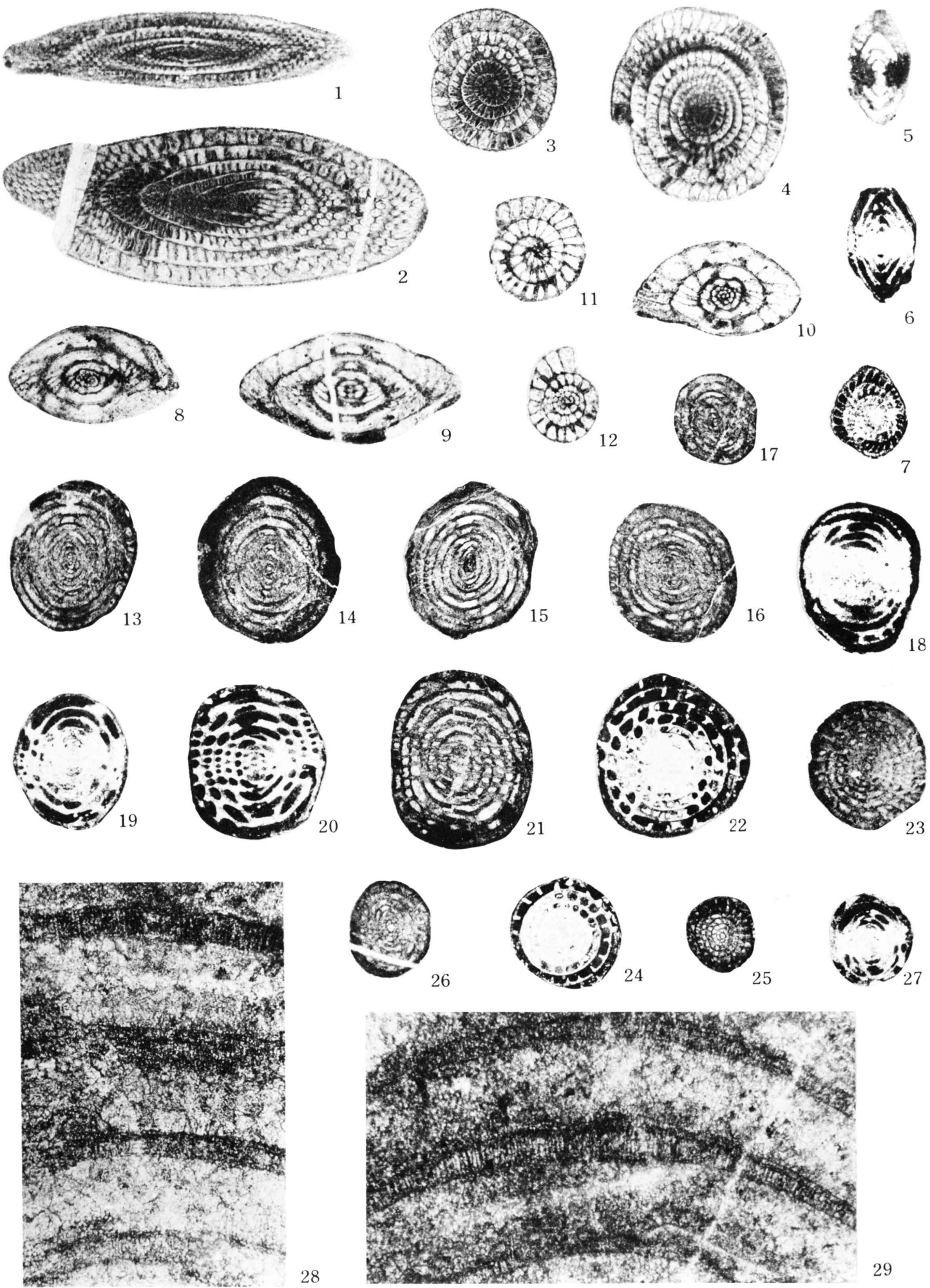
Plate 13 


\section{Explanation of Plate 13}

Figs. 1-6. Neoschwagerina simplex Ozawa (See also Plate 14)

1, Axial (slightly diagonal) section, GKD 12128; 2, tangential (nearly axial) section, GKD 12114; 3, sagittal section, GKD 12106; 4, enlarged figure of a part of the same specimen as figure $2 ; 5$, enlarged figure of a part of the same specimen as figure 1 of Plate $14 ; 6$, enlarged figure of a part of the same specimen as figure 3 of Plate 14.

$1-3$, x 10; 4-6, x 100. 1 from loc. $\mathrm{Km} 5002$ (b member) in Kozakidani; 2-4 from loc. $\mathrm{Km} \mathrm{7574,} \mathrm{d} \mathrm{(f} \mathrm{member)} \mathrm{in} \mathrm{Mameguri-dani;} 5$ from loc. $\mathrm{Km} 7566$ (d member) in Kozaki-dani, all in Sakamotomura.

Figs. $7-13 . \quad$ Cancellina tenuitesta sp. nov. ...................................................114

7. Axial section of the holotype, GKD 12292; 8, axial section of a paratype, GKD 12097; 9 tangential section of a paratype, GKD 12111; 10 , diagonal section of a paratype, GKD 12110; 11, sagittal section of a paratype, GKD 12115; 12, enlarged figure of a part of the same specimen as figure $11 ; 13$, enlarged figure of a part of the same specimen as figure 7 .

$7-11, \times 10 ; 12,13, \quad$ x 100 . All from loc. $\mathrm{Km} 7574$ (f member) in Mameguri-dani, Sakamoto-mura. 

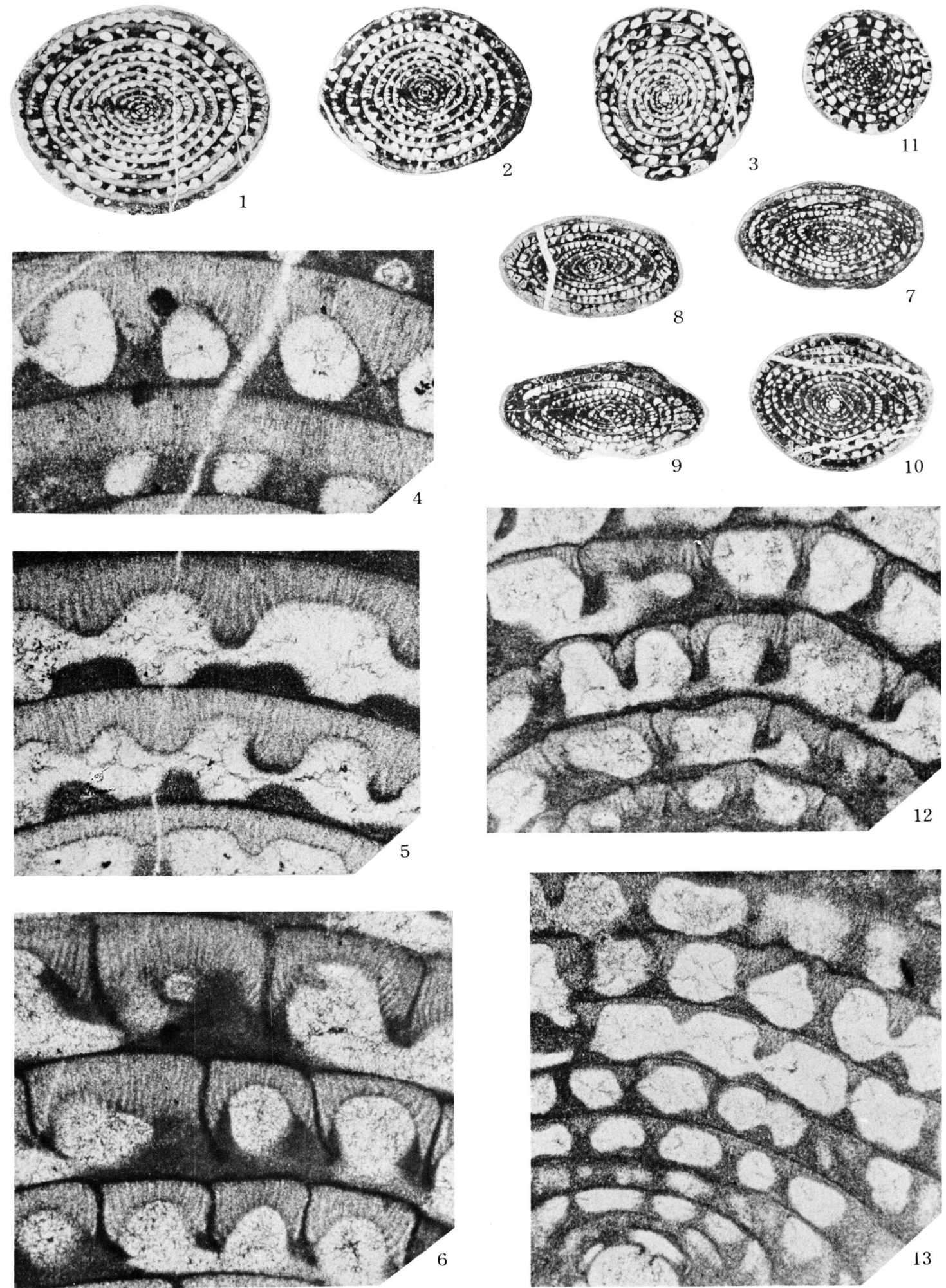

K. Kanmera: Fusulines of the Kozaki Formation 
Plate 14 


\section{Explanation of Plate 14}

All figures are $\mathrm{x} 10$, unless otherwise stated

Figs. 1-6. Neoschwagerina simplex OzaWa (See also Plate 13)

1, Tangential (nearly axial) section, GKD 12108; 2, sagittal section, GKD 12086; 3, sagittal section, GKD 12305; 4, sagittal section of a microspheric from, GKD 12082; 6, oblique section, GKD 12085, a.

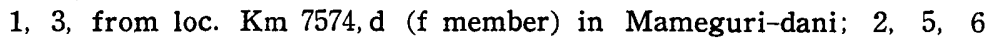
from loc. $\mathrm{Km} 7566$ (d member), and 4 from loc. $\mathrm{Km} \mathrm{5007,} \mathrm{b} \mathrm{(d}$ member), both in Kozaki-dani, Sakamoto-mura.

Figs. 7-14. Misellina claudiae (DEPRAT)

7, Axial section, GKD 12077; 8, slightly diagonal axial section, GKD 12078; 9, tangential (nearly axial) section, GKD 12225; 10, tangential section, GKD 12223; 11-13, sagittal sections, GKD 12169, 12231, 12229, a; 14, slightly diagonal sagittal section, GKD 12229, b.

7, 8, from loc. $\mathrm{Km} \mathrm{7566,} \mathrm{a} \mathrm{(d} \mathrm{member)} \mathrm{in} \mathrm{Mameguri-dani;} \mathrm{9,} \mathrm{10,}$ 12-14 from loc. $\mathrm{Km} 7584$ (b member) in Éri-dani; 11 from loc. $\mathrm{Km}$ 5004, j (b member) in Kozaki-dani; all in Sakamoto-mura.

Figs. 15-18. Pseudodoliolina aff. pseudolepida pseudolepida (Deprat)

15. Axial section, GKD 12308, a; 16, axial section, GKD 12113; 17, tangential section, GKD 12098; 18, enlarged figure of a part of the same specimen as fig. 15, illustrating the structure of the spirotheca, $\times 100$.

All from loc. $\mathrm{Km} 7574$ (f member) in Mameguri-dani, Sakamotomura.

Figs. 19-21. Parafusulina (Parafusulina?) sp.

19, Axial section, GKD 12435; 20, axial section, GKD 12431; 21, axial section, GKD 12184.

19, 20 from loc. $\mathrm{Km} 5209$ (probably b member) in Uminoura, Tanoura-mura, 21 from loc. $\mathrm{Km} 5004, \mathrm{~g}$ (b member) in Kozaki-dani, Sakamoto-mura.

Figs. 22-24. Nagatoella sp.

22, Axial (slightly diagonal) section (immature), GKD 12166, a; 23, axial section (immature), GKD 12166, b; 24, sagittal section (immature), GKD 12161.

All from loc. $\mathrm{Km} 5004, \mathrm{j}$ (b member) in Kozaki-dani, Sakamoto-mura.

Photos by Kanmera 

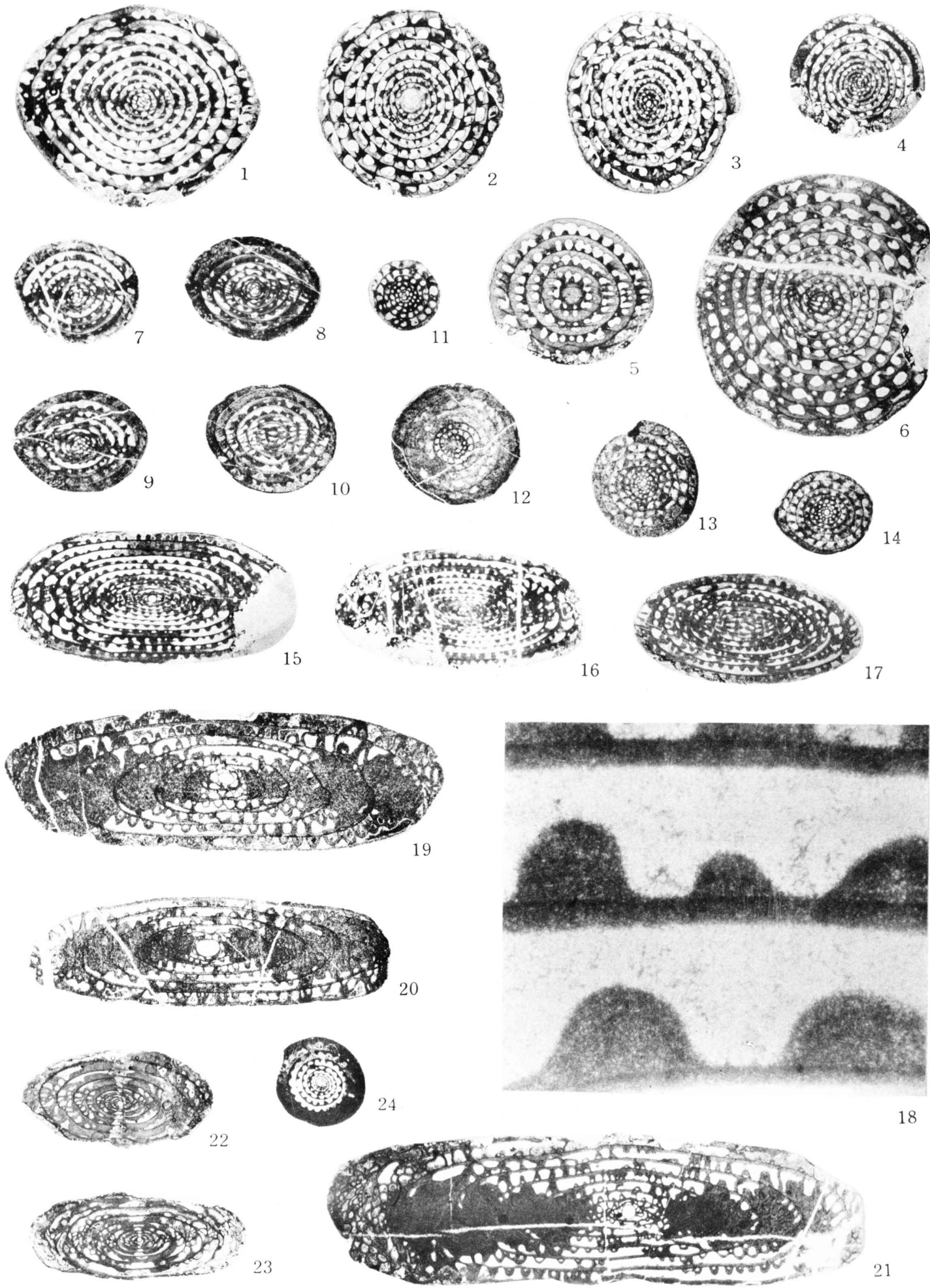

K. Kanmera: Fusulines of the Kozaki Formation 
Plate 15 


\title{
Explanation of Plate 15
}

\author{
All figures $\times 10$
}

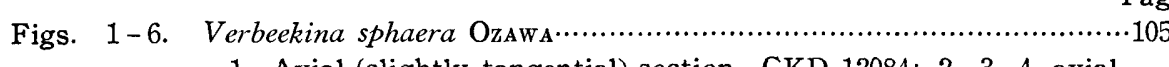

1, Axial (slightly tangential) section, GKD 12084; 2, 3, 4, axial sections, GKD 12052, 12067, 12127; 5, oblique section, GKD 12043, b; 6, parallel section, GKD 12043, a.

1 from loc. $\mathrm{Km} 7566, \mathrm{~b}$ (d member); 2, 3, 5, 6 from loc. $\mathrm{Km} \mathrm{5007,} \mathrm{b} \mathrm{(e} \mathrm{member);} 4$ from loc. $\mathrm{Km} 5002$ (b member); all in Kozaki-dani, Sakamoto-mura.

Figs. 7, 8. Verbeekina sp.

7 , incomplete tangential section, GKD 12085; 8, incomplete tangential (nearly axial) section, GKD 12116.

7 from loc. $\mathrm{Km} \mathrm{7566,c} \mathrm{(d} \mathrm{member)} \mathrm{in} \mathrm{Kozaki-dani;} \mathrm{8,} \mathrm{from}$ loc. $\mathrm{Km} \mathrm{7574,} \mathrm{b} \mathrm{(f} \mathrm{member)} \mathrm{in} \mathrm{Mameguri-dani;} \mathrm{both} \mathrm{in} \mathrm{Saka-}$ moto-mura.

Figs. 9-13, 14(?). Parafusulina (Skinnerella) gruperaensis (Tномеsоn and Miller) ……...95 9 , incomplete axial section, GKD $12280 ; 10,11$, axial sections, GKD 12250, 12252; 12, 13, sagittal sections, GKD 12247, 12252; 14, axial section, GKD 12072 .

9 from loc. $\mathrm{Km} 7584$ (b member), 10-13 from loc. $\mathrm{Km} \mathrm{7582,} \mathrm{b}$ (b member); both in Éri-dani; 14 from loc. $\mathrm{Km} \mathrm{7566,} \mathrm{a} \mathrm{(d}$ member) in Kozaki-dani, Sakamoto-mura.

Photos by Kanmera 

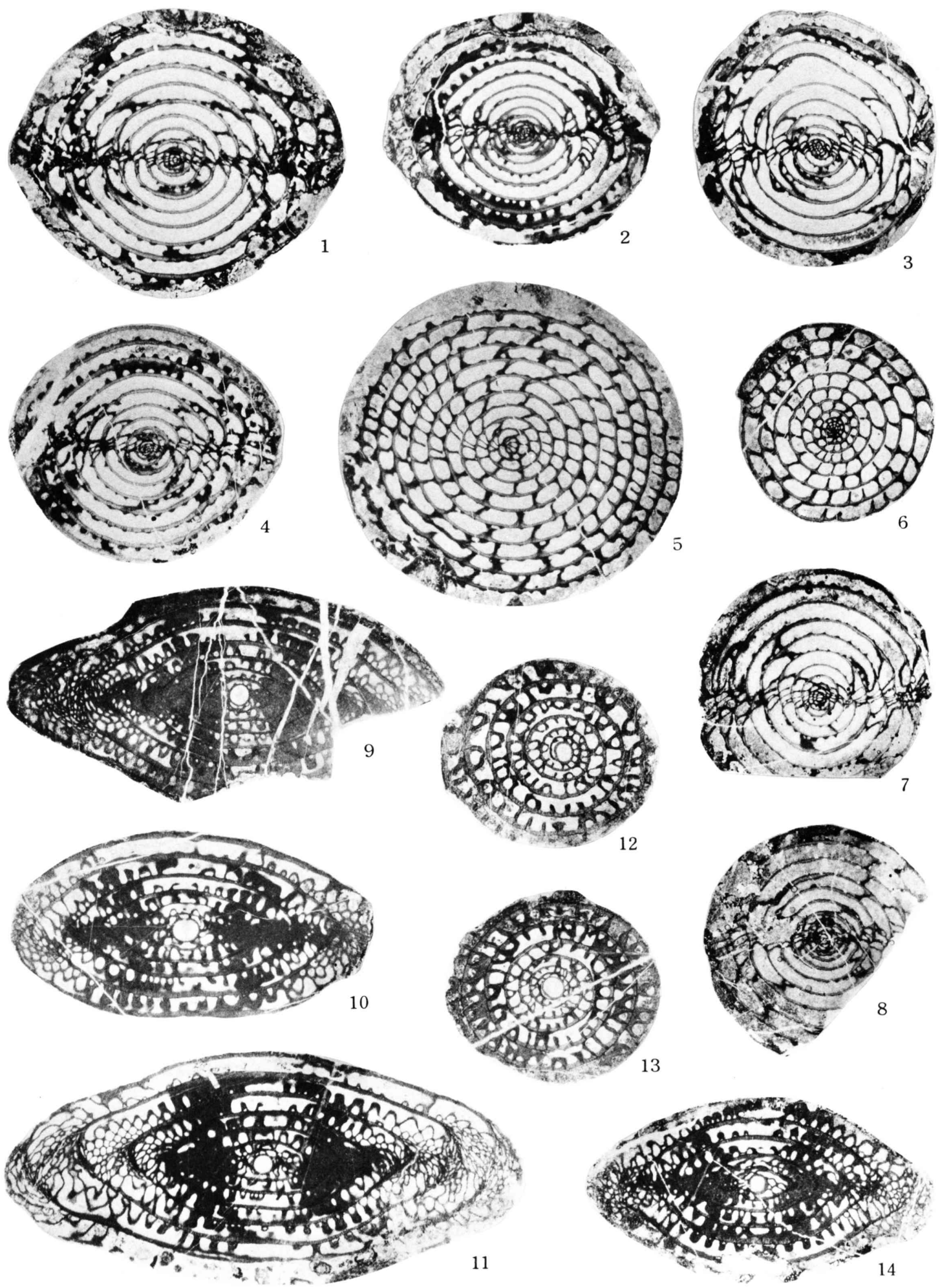

K. Kanmera: Fusulines of the Kozaki Formation 
Plate 16 


\section{Explanation of Plate 16}

\section{All figures $\mathrm{x} 10$}

Figs. 1-5. Parafusulina (Skinnerella) figueroai (Thoмpson and MiLLer) ....

1. Slightly diagonal axial section, GKD 12182; 2 , axial section, GKD 12183; 3, axial section (incomplete), GKD 12177; 4, 5, asgittal sections, GKD 12179, 12180;

All from loc. $\mathrm{Km} 5004, \mathrm{~g}$ (b member) in Kozaki-dani, Sakamotomura.

Figs. 6, 7. Parafusulina (Parafusulina) kaerimizensis (Ozawa)

(See also Plates 17, 18)

6, Slightly diagonal axial section, GKD 12004; 7, slightly diagonal axial section, GKD 12029.

All from loc. $\mathrm{Km} \mathrm{5007,} \mathrm{a} \mathrm{(e} \mathrm{member)} \mathrm{in} \mathrm{Kozaki-dani,} \mathrm{Sakamoto-}$ mura.

Photos by Kanmera 


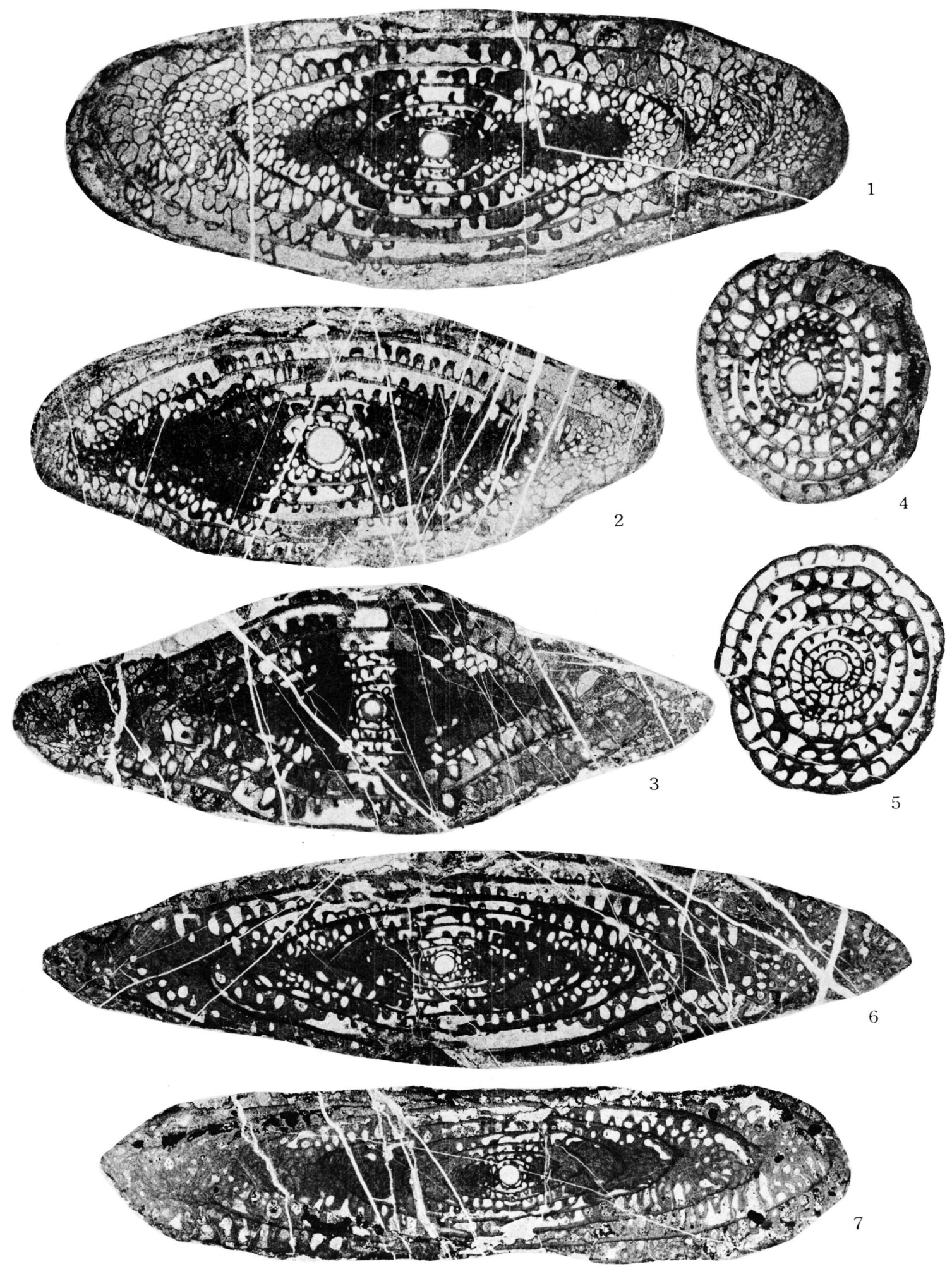

K. Kanmera: Fusulines of the Kozaki Formation 
Plate 17 


\section{Explanation of Plate 17}

\section{All figures $\times 10$}

Figs. 1,2, 3 (?), 4. Parafusulina (Skinnerella) cf. sapperi (Staff)

1, Axial (slightly diagonal) section, GKD 12016, 2, tangential section, GKD 12009; 3 axial section (silicified in part), GKD 12118; 4, sagittal (slightly diagonal) section, GKD 12024.

1, 2, 4 from loc. $\mathrm{Km} \mathrm{5007,} \mathrm{a} \mathrm{(e} \mathrm{member)} \mathrm{in} \mathrm{Kozaki-dani,} \mathrm{and}$ 3 from loc. $\mathrm{Km} \mathrm{7574,b} \mathrm{(f} \mathrm{member)} \mathrm{in} \mathrm{Mameguri-dani;} \mathrm{both} \mathrm{in}$ Sakamoto-mura.

Figs. 5-7. Parafusulina (Parafusulina) kaerimizensis (Ozawa)

(See also Plates, 16, 18)

5 , incomplete axial section, GKD 12025; 6 , axial (slightly diagonal) section, GKD 12056; 7, saggital section, GKD 12311.

5, 6, from loc. $\mathrm{Km} 5007$ (e member) in Kozaki-dani; 7 from loc. $\mathrm{Km} 7574$ (f member) in Mameguri-dani; both in Sakamotomura.

Photos by Kanmera 

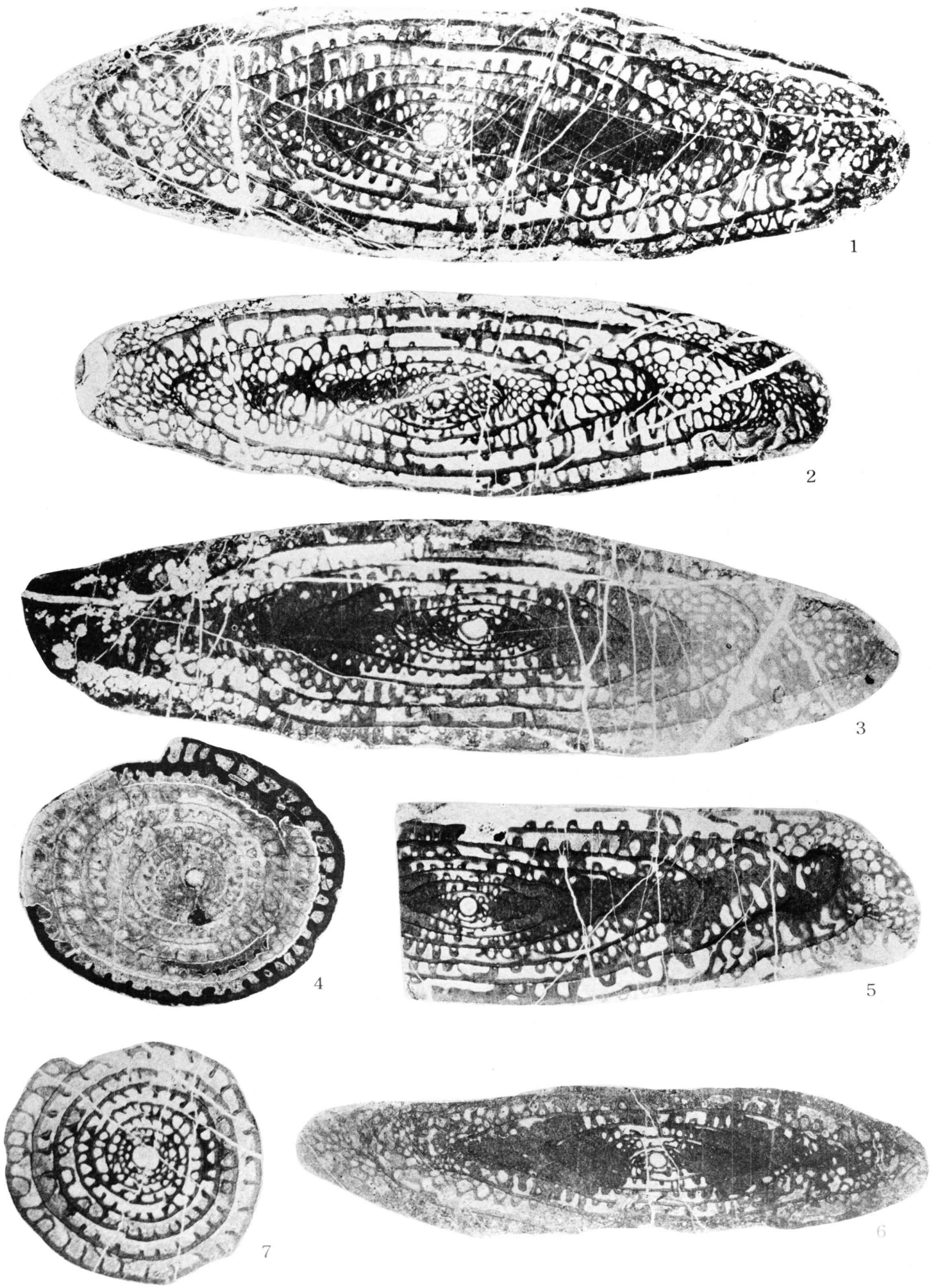

K. Kanmera: Fusulines of the Kozaki Formation 
Plate 18 


\section{Explanation of Plate 18}

\section{All figures $\times 10$}

\footnotetext{
Figs, 1-4. Parafusulina (Skinnerella) nakamigawai MoRIKAWA and HoRIGUCHI ……........98 1, 2, Axial sections, GKD 12416, 12402; 3, 4, sagittal sections, GKD $12418,12428$.

All from loc. $\mathrm{Km} 5209$ (probably b member) in Uminoura, Tanouramura.
}

Figs. 5-8. Parafusulina (Parafusulina) kaerimizensis (OzawA)

(See also Plates 17, 18) 101

5, Axial (slightly diagonal) section, GKD 12066; 6, incomplete axial section, GKD 12051; 7, 8, sagittal seotions, GKD 12107, 12045.

5, 6, 8 from loc. $\mathrm{Km} 5007$ (e member) in Kozaki-dani, 7 from loc. $\mathrm{Km} 7547$ (f member) in Mameguri-dani, both in Sakamoto-mura.

Photos by Kanmera 

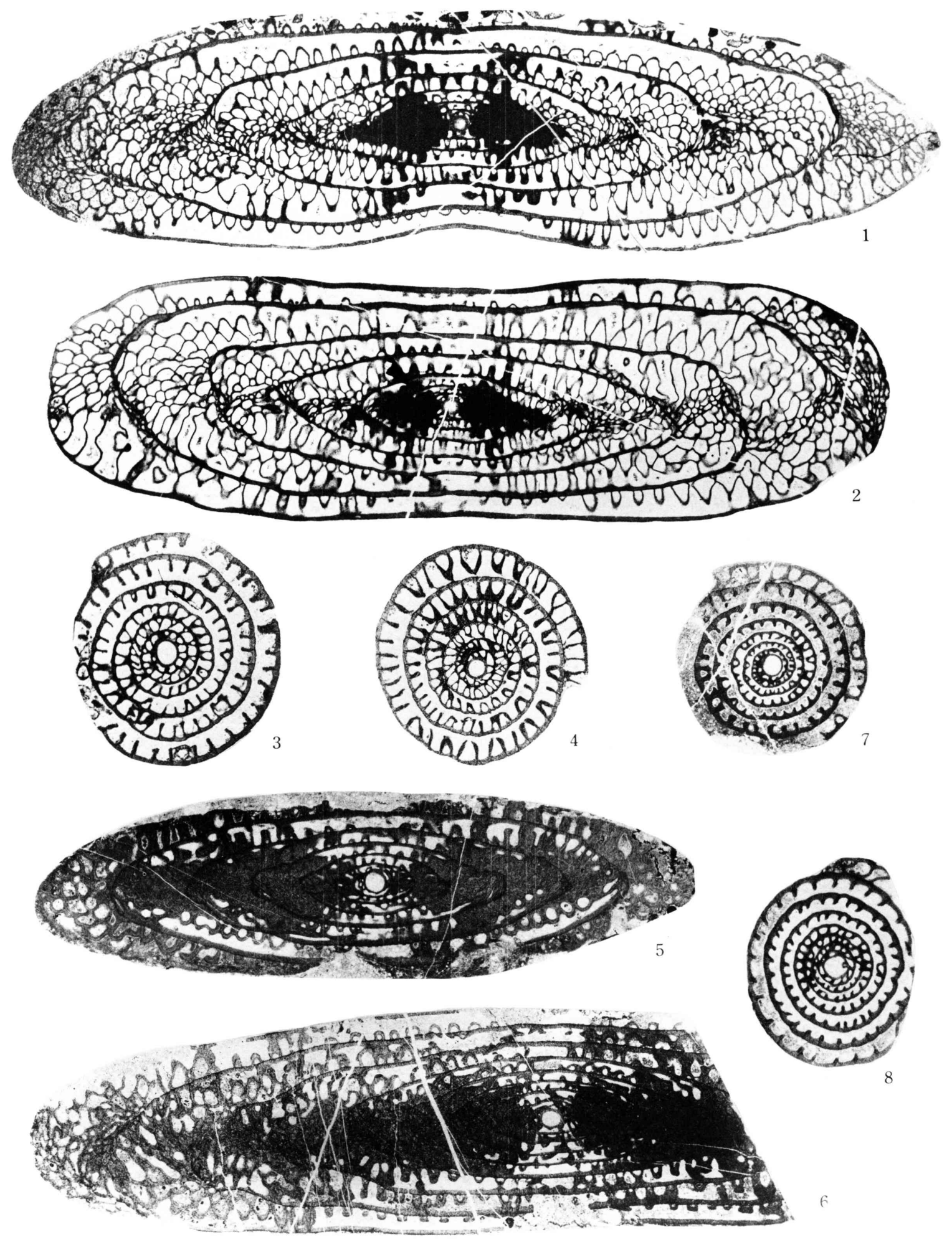

K. Kanmera: Fusulines of the Kozaki Formation 
Plate 19 


\section{Explanation of Plate 19}

Figs. 1-7. Monodiexodina kumensis sp. nov

1 , Axial section of the holotype, GKD 12447; 2, 3, incomplete axial sections of paratypes, GKD 12454, 12448; 4, a part of tangential section of a paratype, GKD 12459; 5,7 , parallel sections of paratypes, GKD 12453, 12449; 6, incomplete sagittal section of a paratype, GKD 12456;

all $\times 10$; loc. $\mathrm{Km} 5004$, b (b member), in Kozaki-dani, Sakamotomura.

Figs. 8, 9. Toriyamaia laxiseptata KANmera (See also Plate 11) 87

8, tangential section, GKD 12438; 9, sagittal section, GKD 12441. x 25; loc. $\mathrm{Km} \mathrm{5004,} \mathrm{d} \mathrm{(b} \mathrm{member)} \mathrm{in} \mathrm{Kozaki-dani,} \mathrm{Sakamoto-mura.}$

Figs. 10-12. Sphaerulina crassispira japonica subsp. nov. (See also Plate 12)

10. Slightly oblique sagittal section of a paratype, GKD $12385 ; 11$, oblique sagittal section of a paratype, GKD 12382; 12, tangential section of a paratype, GKD 12386.

All $\mathrm{x} 10$; loc. $\mathrm{Km} 7566$, c (d member) in Kozaki-dani, Sakamotomura.

Figs. 13. Nagatoella sp. (See also Plate 14)

Axial section, GKD 12445; $\mathrm{x}$ 10; loc. $\mathrm{Km} \mathrm{5004,} \mathrm{d} \mathrm{(b} \mathrm{member)} \mathrm{in}$ Kozaki-dani, Sakamoto-mura.

Figs. 14. Schwagerina? sp. cf. "Pseudofusulina" chihsiaensis (LEE) …......................93 Axial section, GKD 12392; x 10; loc. $\mathrm{Km} 7571$ (d member) in Mameguri-dani, Sakamoto-mura.

Figs. 15. Neoschwagerina simplex Ozawa (See also Plate 13)

Axial section, GKD 12456; x 10; loc. Km 5107 (probably e member) west of Oshino, Sakamoto-mura.

Figs. 16,17. Cancellina tenuitesta sp. nov. (See also Plate 13)

Axial sections of paratypes, GKD 12469, 12491; x 10; loc. Km 5107 (probably e member) west of Oshino, Sakamoto-mura.

Photos by KanMera 

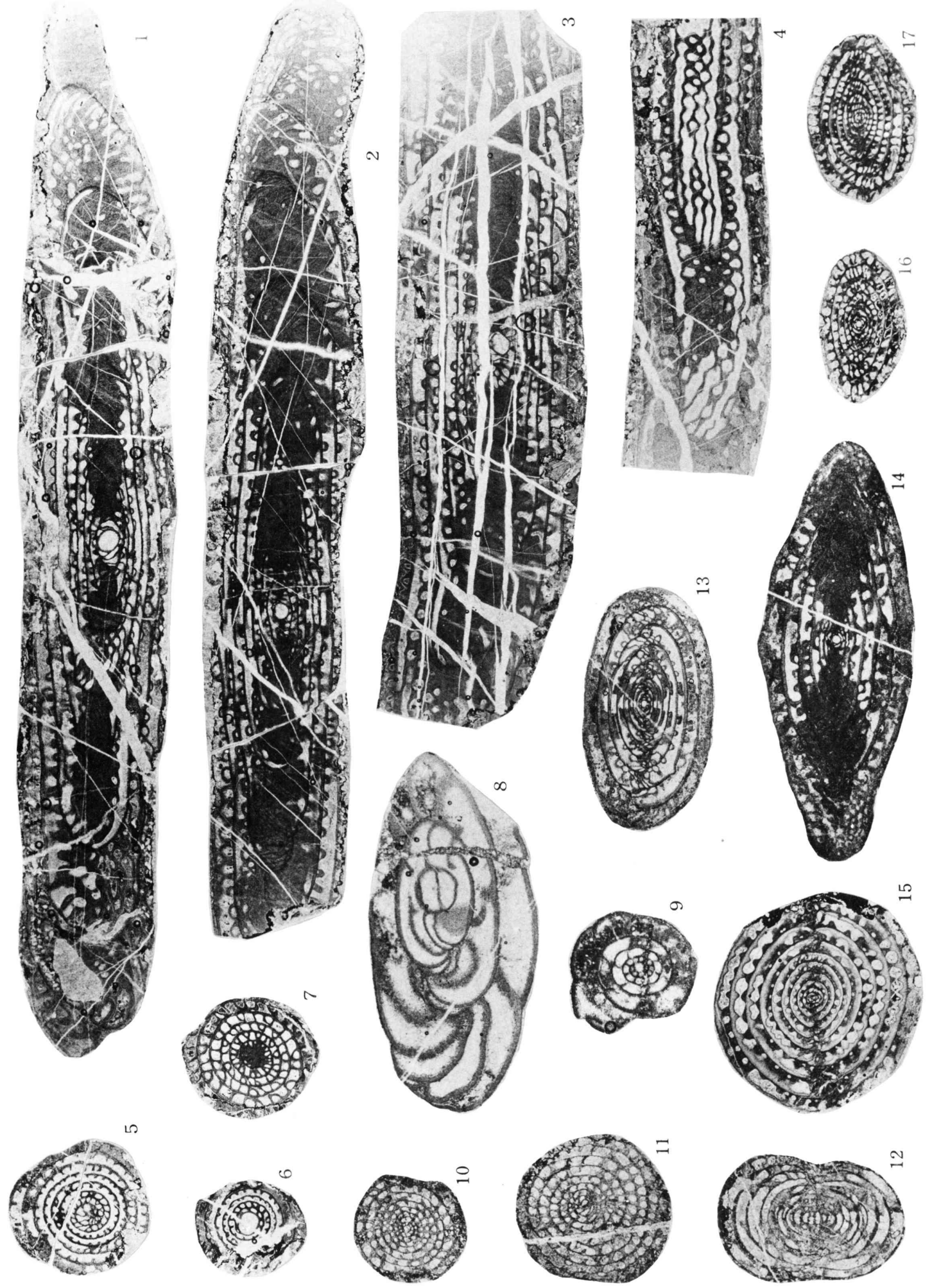

K. Kanmera: Fusulines of the Kozaki Formation 